\title{
Recent Advances and Applications of Semiconductor Photocatalytic Technology
}

\author{
Fubao Zhang ${ }^{1}$, Xianming Wang ${ }^{2}$, Haonan Liu ${ }^{1,2}$, Chunli Liu ${ }^{1}$, Yong Wan ${ }^{1, *}$, Yunze Long ${ }^{1, *}$ and \\ Zhongyu Cai ${ }^{3,4, *}$ \\ 1 College of Physics Science, Qingdao University, Qingdao 266071, China; fbzhang18@163.com (F.Z.); \\ liuhaonantongxue@126.com (H.L.); liuc11827@163.com (C.L.) \\ 2 State Key Laboratory of Marine Coatings, Marine Chemical Research Institute Co., Ltd., Qingdao 266071, \\ China; wxm133701@163.com \\ 3 Department of Chemistry, University of Pittsburgh, Pittsburgh, PA 15260, USA \\ 4 Department of Chemical and Biomolecular Engineering, National University of Singapore, \\ 4 Engineering Drive 4, Singapore 117585, Singapore \\ * Correspondence: wanyongqd@hotmail.com (Y.W.); yunze.long@163.com (Y.L.); \\ caizhongyu@alumni.nus.edu.sg (Z.C.)
}

Received: 25 April 2019; Accepted: 12 June 2019; Published: 18 June 2019

check for updates

\begin{abstract}
Along with the development of industry and the improvement of people's living standards, peoples' demand on resources has greatly increased, causing energy crises and environmental pollution. In recent years, photocatalytic technology has shown great potential as a low-cost, environmentally-friendly, and sustainable technology, and it has become a hot research topic. However, current photocatalytic technology cannot meet industrial requirements. The biggest challenge in the industrialization of photocatalyst technology is the development of an ideal photocatalyst, which should possess four features, including a high photocatalytic efficiency, a large specific surface area, a full utilization of sunlight, and recyclability. In this review, starting from the photocatalytic reaction mechanism and the preparation of the photocatalyst, we review the classification of current photocatalysts and the methods for improving photocatalytic performance; we also further discuss the potential industrial usage of photocatalytic technology. This review also aims to provide basic and comprehensive information on the industrialization of photocatalysis technology.
\end{abstract}

Keywords: photocatalysis; application; reaction mechanism; preparation method; catalyst modification; application

\section{Introduction}

As industrialization accelerates, both energy and environmental issues arise. Nowadays, the world's major energy sources are still fossil energies, such as coal, oil, and natural gas. With the continuous development of industrialization, most fossil fuels are expected to be depleted in 21st century. In addition, the use of fossil energy also causes severe pollution to the environment. In recent years, more and more serious air pollution and water pollution directly threaten human life and health [1]. In 1972, Fujishima and Honda found that the $\mathrm{TiO}_{2}$ electrode can break down hydrogen in aquatic production under sunlight [2]. Since then, photocatalysis has attracted intense attention due to its direct conversion of solar energy to easily stored hydrogen, as well as its lack of environmental pollution. Frank and Bard then successfully oxidized $\mathrm{CN}^{-}$to $\mathrm{OCN}^{-}$using $\mathrm{TiO}_{2}$ as a photocatalyst, an act which promoted and accelerated the application of photocatalysts in wastewater treatment [3]. Since then, $\mathrm{TiO}_{2}$ has been used as a photocatalyst for a wide range of applications in the field of environmental management. The detailed research of photocatalyst technology also extends the potential application 
range of photocatalysts. The main research directions at this stage are photocatalyst disinfection [4-6], photocatalytic hydrogen production [7-11], photocatalytic reduction of $\mathrm{CO}_{2}$ [12-15], photocatalyst wastewater treatment [16-20], and air purification [21-23]. However, photocatalytic technology is only at the laboratory stage, and there is still a long journey to apply this technology in practice [24].

With the continuous development of photocatalytic technology, researchers have published many excellent reviews. For example, Wang et al. [25] reviewed the use of nitrogen doping to modify oxide photocatalysts to improve their photocatalytic performance. Li et al. [26] outlined the application of graphene and its composites to photocatalysts. Zhou et al. [27] gave an overview of the all-solid Z-Scheme photocatalyst system, including the configuration, structure, optimization, and application of a Z-scheme photocatalyst system. Boyjoo et al. [24] presented the application of photocatalysts in air treatment, including catalyst development and reactor design. Wang et al. [28] gave the latest developments and challenges in photocatalytic sterilization. Most of the current reviews focus on only one or several aspects of photocatalysts. A complete summary of the main content of photocatalysts is still missing.

In anticipation of helping researchers with information on more efficient photocatalysts, we have summarized some common preparation and modification methods of photocatalysts. Meanwhile, a series of advances in photocatalyst technology have been reviewed to facilitate researchers' understanding of the latest research trends in photocatalysts. This review article aims to summarize researchers' efforts on the use of various preparation and modification methods to prepare ideal photocatalysts. In addition, this review also promotes the development of photocatalytic technology and even the industrialization of photocatalytic technology.

\section{Photocatalytic Mechanism and Influencing Factors}

\subsection{Reaction Mechanism}

Photocatalytic reaction is a chemical reaction that takes place under the joint action of light and the photocatalyst. This technology possesses several advantages, including environmental protection, the complete degradation of pollutants, and no secondary pollution. Figure 1 shows the basic principle of a photocatalytic reaction [29-40].

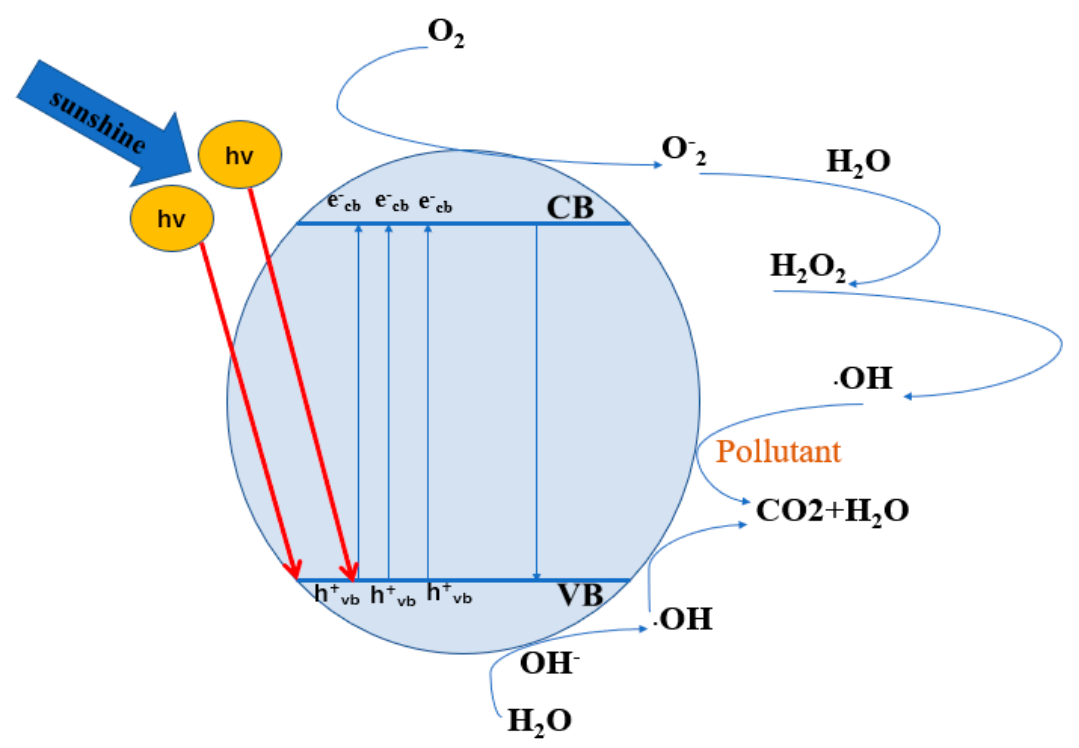

Figure 1. Photocatalytic reaction mechanism.

From the point of semiconductor photochemistry, photocatalytic action is the light-induced redox reaction of semiconductors. A semiconductor has an energy band structure composed of a low energy valence band (VB) and a high energy conduction band (CB), and the band gap between a conduction 
band and a valence band is called a forbidden band. When the energy of the incident light is larger than the band gap of the semiconductor, the electrons in the VB of the semiconductor are excited to the CB by photons, and the corresponding holes are generated in the VB. Photogenerated electrons and holes are separated by an electric field and move to the surface of semiconductor particles. The photogenerated pores have strong oxidizing properties and can oxidize substances adsorbed on the surface or solution of the semiconductor.

The detailed process of a photocatalytic reaction is as follows. Under a certain energy of light, electrons on a VB are excited and jump to a $\mathrm{CB}$, and the holes stay on the VB. The electrons on the $\mathrm{CB}$ move to the surface of the catalyst and participate in a reduction reaction, and the holes on the VB diffuse to the photocatalyst surface and are involved in an oxidation reaction. In the course of the reaction, the electrons can form $\mathrm{H}_{2} \mathrm{O}_{2}$ or a superoxide radical $\mathrm{O}_{2}{ }^{-}$with $\mathrm{H}^{+}$and dissolved $\mathrm{O}_{2}$ in the aqueous solution, and the holes can oxidize $\mathrm{OH}^{-}$to produce hydroxyl radicals $\cdot \mathrm{OH}$ and, thus, achieve the effect of degrading pollutants [41-44].

\subsection{Influencing Factors}

The photocatalytic reaction process is complicated and has many intermediate stages. Therefore, many factors can influence the photocatalytic reaction [45-55]. The characteristics of the catalyst itself; the surface condition of the catalyst (charge, adsorbed material, defect, composition); the reaction medium conditions ( $\mathrm{pH}$, solvent); the type and concentration of reactants, adsorption, and product analysis of reactants; oxygen concentration; light source (wavelength, intensity, distance)—all of these are key factors that affect the photocatalytic reaction. The influence of several factors on the photocatalytic reaction is summarized in Table 1.

Table 1. Effects of influencing factors on photocatalytic reaction.

\begin{tabular}{ccl}
\hline Influencing Factors & \multicolumn{1}{c}{ Effect on Photocatalysis } \\
\hline Catalyst concentration & $\begin{array}{l}\text { - The reaction rate increases with the increase of the catalyst concentration. } \\
\text { - Above a certain dose, the reaction rate decreases as the catalyst } \\
\text { concentration increases. }\end{array}$ \\
\hline $\begin{array}{c}\text { Light source and } \\
\text { light intensity }\end{array}$ & $\begin{array}{c}\text { Light } \\
\text { intensity }\end{array}$ & $\begin{array}{l}\text { - Provide light of different wavelengths. } \\
\text { - Improve light intensity and promote photocatalytic } \\
\text { reaction. }\end{array}$ \\
\hline PH value & & - Related to target degradation products. \\
\hline Plus oxidants & $\begin{array}{l}\text { - Reducing the recombination of photogenerated electrons and holes to } \\
\text { improve photocatalytic efficiency. }\end{array}$ \\
\hline Inorganic ion & Anion & $\begin{array}{l}\text { - Improve the separation speed of photogenerated electrons and holes and } \\
\text { promote photocatalytic reaction. }\end{array}$ \\
& Cation & $\begin{array}{l}\text { - Becomes a scavenger of hydroxyl radicals, forming anion radicals. } \\
\text { - The competitive adsorption of active sites on the surface of the catalyst } \\
\text { may affect the photocatalytic degradation of organics. }\end{array}$ \\
\hline Temperature & - Has little effect. \\
\hline
\end{tabular}

\section{Common Classification of Photocatalysts}

\subsection{Oxide Photocatalyst}

\subsection{1. $\mathrm{TiO}_{2}$-Based Photocatalyst}

In 1976, Carey et al. discovered that nano- $\mathrm{TiO}_{2}$ could dechlorinate polychlorinated biphenyls, a hard-degradable organic compound, under ultraviolet irradiation [18,56-61], and opened a new chapter in photocatalytic degradation of semiconductor nanomaterials. In 1980, Bard et al. proposed a photocatalytic mechanism using $\mathrm{TiO}_{2}$ as a catalyst [62], which promoted the development of $\mathrm{TiO}_{2}$ in the field of photocatalysis. 
$\mathrm{TiO}_{2}$ has three crystal forms-rutile, brookite, and anatase. Among these three crystal structures, anatase and rutile-type $\mathrm{TiO}_{2}$ are often used as photocatalysts [63]. $\mathrm{TiO}_{2}$-based photocatalysts have been widely used in air purification, water pollutants degradation, antibacterial disinfection, deodorant, and antifog, among other applications, due to their high activity, stable properties, low cost, and non-toxic environment.

$\mathrm{TiO}_{2}$ has a wide band gap (about $3.2 \mathrm{eV}$ ). Therefore, $\mathrm{TiO}_{2}$ can only absorb ultraviolet light when used as a photocatalyst. However, ultraviolet radiation occupies only $5 \%$ of sunlight, which greatly limits the application of $\mathrm{TiO}_{2}$ in the visible range. A series of modifications to $\mathrm{TiO}_{2}$ is usually carried out, thereby improving the utilization of visible light by $\mathrm{TiO}_{2}$ and reducing the photogenerated electron-hole recombination rate on the surface of $\mathrm{TiO}_{2}$. In the end, its photocatalytic efficiency can be improved. As shown in Figure 2, common methods used to improve photocatalytic efficiency include semiconductor surface photosensitization, semiconductor surface noble metal deposition, metal/nonmetal doping, and complex semiconductor modification.

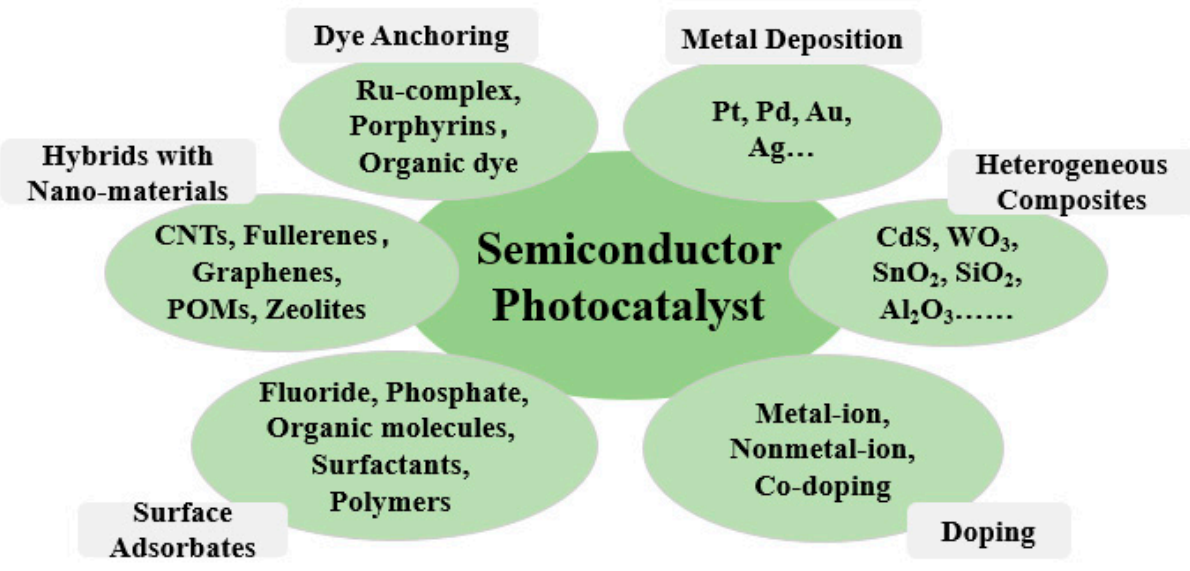

Figure 2. Various modification methods of a semiconductor photocatalyst.

\subsection{2. $\mathrm{Bi}_{2} \mathrm{O}_{3}$-Based Photocatalyst}

Bi-based oxides are an important class of functional materials that are widely used in many fields [64]. For example, they are used as electronic ceramic materials (zinc oxide varistors, ceramic capacitors, ferrite magnetic materials), electrolyte materials, high-temperature superconducting materials, and materials for photoelectric conversion. Among them, $\mathrm{Bi}_{2} \mathrm{O}_{3}$ possesses its own unique properties, such as a high electrical conductivity, low energy bandgap (about $2.8 \mathrm{eV}$ ), and low energy band structure, which means that $\mathrm{Bi}_{2} \mathrm{O}_{3}$ can absorb visible light in the solar spectrum. Therefore, $\mathrm{Bi}_{2} \mathrm{O}_{3}$ has great potential for photocatalysis application $[65,66]$.

The semiconductor $\mathrm{Bi}_{2} \mathrm{O}_{3}$ mainly has four crystal forms, including $\alpha, \beta, \gamma$, and $\delta$. The band gaps of $\beta-\mathrm{Bi}_{2} \mathrm{O}_{3}$ and $\alpha-\mathrm{Bi}_{2} \mathrm{O}_{3}$ are $2.58 \mathrm{eV}$ and $2.85 \mathrm{eV}$, respectively, which can absorb visible light with wavelengths exceeding $400 \mathrm{~nm}$ [65]. $\alpha-\mathrm{Bi}_{2} \mathrm{O}_{3}$ is the most widely used among these four different $\mathrm{Bi}_{2} \mathrm{O}_{3}$ semiconductors in photocatalytic reactions, since $\alpha-\mathrm{Bi}_{2} \mathrm{O}_{3}$ is the most thermodynamically stable among these four crystal structures [67].

The development of Bi-based semiconductor materials obviously solves the problem of the visible light absorption of $\mathrm{TiO}_{2}$. However, a low quantum efficiency and photogenerated carrier recombination is still an urgent problem that needs to be solved for the Bi-based photocatalysts. The doping modification of the photocatalyst is an effective method for improving its photocatalytic performance. Commonly used modification methods include semiconductor surface photosensitization, semiconductor surface noble metal deposition, metal/nonmetal doping, and complex semiconductor modification. To date, Bi-based photocatalysts have achieved a variety of important research results in the applications of atmospheric purification, organic wastewater treatment, heavy metal ion removal, and sterilization [68-84]. 


\subsubsection{Other Oxide Photocatalysts}

Transition metal elements of the IV cycle, such as titanium, chromium, manganese, iron, cobalt, nickel, copper, and zinc [85-88], as well as their corresponding oxides, have excellent physical and chemical properties. These excellent physicochemical properties include a high redox potential, multivalence, chemical resistance, and a high temperature resistance. The storage of transition metal elements is relatively abundant and has a low price, which means that transition metal oxides have good application prospects in photocatalysis.

Next, we will introduce the three kinds of transition metal oxides generally used, $\mathrm{ZnO}, \mathrm{WO}_{3}$, and $\mathrm{Fe}_{2} \mathrm{O}_{3}$.

$\mathrm{ZnO}$ is one of the few oxide semiconductor materials that can achieve a quantum size effect, and $\mathrm{ZnO}$ has good UV absorption and piezoelectric properties. The forbidden band width of $\mathrm{ZnO}$ is $3.2 \mathrm{eV}$, which corresponds to ultraviolet with a wavelength of $387 \mathrm{~nm}$. Studies on $\mathrm{ZnO}$ have found that there is a certain relationship between the surface composition and structure of $\mathrm{ZnO}$ nanoparticles and their photocatalytic properties. Oxygen vacancies on the $\mathrm{ZnO}$ surface tend to capture photogenerated electrons, and there is a strong interaction between oxygen vacancies and adsorbed oxygen, which is beneficial for the oxidation reactions.

$\mathrm{WO}_{3}$ is one of the metal oxides having photocatalytic activity. $\mathrm{WO}_{3}$ shows several advantages, including a large specific surface area, excellent absorbing capability, and its potential to be used as invisible material. The band gap of $\mathrm{WO}_{3}$ is $2.8 \mathrm{eV}$, and $\mathrm{WO}_{3}$ is stable. $\mathrm{WO}_{3}$ can be used both as a main catalyst and as a cocatalyst.

Iron has long been investigated as an important meta-element in the redox reaction. Among iron oxides, $\mathrm{Fe}_{2} \mathrm{O}_{3}$ has been widely studied for its high photocatalysis activity. $\mathrm{Fe}_{2} \mathrm{O}_{3}$ is an n-type semiconductor, having a forbidden band width of $2.2 \mathrm{eV}$, a strong light absorption capability in the visible light region, and the ability to absorb a part of sunlight. $\mathrm{Fe}_{2} \mathrm{O}_{3}$ can be used as a reducing agent for the photocatalytic reduction of silver ions $[89,90]$ and can also be used to decompose reactive dyes [91-93].

\subsection{Non-Oxide Photocatalyst}

Many non-oxides also have good photocatalytic properties [94,95]. Among them, semiconductor metal sulfides have attracted intense attention because of their special structure and excellent physical and chemical properties. Some such non-oxides include as molybdenum sulfide $\left(\mathrm{MoS}_{2}\right)$, tungsten sulfide (WS), copper sulfide (CuS) [96], zinc sulfide (ZnS) [97,98], and cadmium sulfide (CdS) [99]. Of course, in addition to the sulfides, nitrides, such as $\mathrm{C}_{3} \mathrm{~N}_{4}$, also show excellent photocatalytic properties.

Next, we will take CdS, CuS, $\mathrm{ZnS}$, and $\mathrm{C}_{3} \mathrm{~N}_{4}$ as examples to demonstrate their applications in photocatalysis.

\subsubsection{CdS Series Photocatalyst}

$\mathrm{CdS}$ is a semiconductor material, having a bandgap of about $2.42 \mathrm{eV}$ and a maximum absorption peak of $514 \mathrm{~nm}$. Therefore, CdS can absorb visible light or ultraviolet light with a wavelength of less than $514 \mathrm{~nm}$, which makes CdS more efficient for visible light photocatalysis [100,101]. In addition, the bandgap position of $\mathrm{CdS}$ semiconductors is well suited for many photocatalytic reactions, such as water decomposition [100] and $\mathrm{CO}_{2}$ reduction [102]. More importantly, the position of the CdS conduction band edge is lower than the position of other common semiconductors (such as $\mathrm{TiO}_{2}, \mathrm{SrTiO}_{3}$, and $\mathrm{ZnO}$ ) [103]; this means that in the photocatalytic reaction, photoelectrons of CdS have a stronger reducing power. Therefore, $\mathrm{CdS}$ has been intensively investigated as a photocatalyst. However, the CdS material is prone to light corrosion, which results in severe limitations on the number of recoverable photocatalyst. To solve this fundamental problem, researchers have proposed some of measures to improve the use ratio of CdS. The most common method is to prepare CdS composite materials using 
different materials or ion doping methods. The CdS composite also enhances the absorption of long wavelength light, thereby achieving the full utilization of the visible part of natural light.

\subsubsection{CuS Series Photocatalyst}

$\mathrm{CuS}$ is a very important metal sulfide semiconductor material with excellent optoelectronic properties, and it is considered to be a typical $\mathrm{P}$ type semiconductor material. CuS has a forbidden band width of $2.2 \mathrm{eV}$, which has good visible light absorption capacity. When the CuS material absorbs the proper photons, electron-hole pairs are generated. Electrons and holes move to the surface of the material and react with water molecules or oxygen molecules on the surface of the material to produce several substances. These substances have high catalytic activity and can degrade the organic matter adsorbed on the surface of the material.

Because of its excellent properties, CuS has found a wide range of optical, electrical, mechanical, and sensor applications [104-107], including solar cells, lithium battery electrodes, photothermal conversion, and photocatalysis [108]. CuS nanomaterials have great potential for photocatalysis due to their appropriate energy band and absorption wavelength [109].

\subsubsection{ZnS Series Photocatalyst}

$\mathrm{ZnS}$ is a group of II-VI wide band gap semiconductor materials with a band gap between 3.6 and $3.8 \mathrm{eV}$. ZnS has two different crystal structures-zinc blende and wurtzite. Among them, zinc blende, also known as $\beta$-ZnS, can stably exist at low temperatures, while wurtzite, also known as $\alpha$-ZnS, can exist stably at temperatures above $1024^{\circ} \mathrm{C}$. ZnS is difficult to oxidize and hydrolyze. More importantly, these properties are still present when the size of $\mathrm{ZnS}$ is reduced to the nanometer scale. Thus, ZnS nanomaterials exhibit good photocatalytic activity [110]. Furthermore, ZnS is easily fabricated, non-toxic, and widely used. To date, many research groups have successfully synthesized low-dimensional nanomaterials such as ZnS nanoparticles [40,98,101,111-117], nanowires [118-122], nanotubes [123-126], and nanosheets [127,128].

Among the methods for enhancing the photocatalytic activity of $\mathrm{ZnS}$, the following three are the most common approaches. (1) The specific surface area is increased by changing the morphology of ZnS [129-131]. The high specific surface area can increase the active site on the ZnS surface and can increase the contact area between $\mathrm{ZnS}$ and the reactant, thereby increasing the photocatalytic activity of ZnS. (2) By altering the electronic properties and band structure of ZnS through doping with other metals and non-metallic elements [132], the absorption rate of $\mathrm{ZnS}$ to visible light is improved, thereby improving the photocatalytic efficiency of ZnS. (3) ZnS forms a heterojunction with other semiconductors [133] or a composite structure with noble metals [134] to reduce the electron-hole recombination rate, thereby improving the photocatalytic performance of $\mathrm{ZnS}$.

\subsubsection{Nitride Series Photocatalyst}

In 1989, Liu and Cohen [135] succeeded in replacing the Si atom with the $\mathrm{sp}^{3}$ hybridization of $\mathrm{C}$ atoms according to the well-known $\beta-\mathrm{Si}_{3} \mathrm{~N}_{4}$ structure. Four sp ${ }^{3}$ hybridized $\mathrm{N}$ atoms are bonded to the $\mathrm{C}$ atom, and three $\mathrm{C}$ atoms are bonded to each $\mathrm{N}$ atom to form a nearly planar structure of the carbon-nitrogen compound. In 1993, Science published one paper on the successful synthesis of $\mathrm{C}_{3} \mathrm{~N}_{4}$ crystals with a hardness higher than that of diamonds using laser sputtering technology in the Harvard University laboratory [136,137], which quickly attracted the attention of the global materials community. By 1996, Teter and Hemley [138] believed that carbon nitride might have a structure of $\alpha$ phase, $\beta$ phase, cubic phase, quasi-cubic phase, and graphite-like phase.

In 2009, Wang et al. [139] reported on a polymer semiconductor material g- $\mathrm{C}_{3} \mathrm{~N}_{4}$ consisting entirely of non-metallic elements. g- $C_{3} N_{4}$ is a graphite-like layered structure, and g- $C_{3} N_{4}$ has an excellent electron/hole transporting ability, a high thermal stability and chemical stability, and a narrow band gap (2.7-2.8 eV). The forbidden bandwidth of $\mathrm{g}-\mathrm{C}_{3} \mathrm{~N}_{4}$ allows it to have a strong light absorption in the visible light region $(400-450 \mathrm{~nm})$. Furthermore, the structure and properties of $g-\mathrm{C}_{3} \mathrm{~N}_{4}$ 
are easy to control, making it a hot research topic in the field of photocatalysts [140,141]. $\mathrm{g}_{-} \mathrm{C}_{3} \mathrm{~N}_{4}$ shows excellent photocatalytic performance in the field of photo hydrolysis, hydrogen production, photodegradation of environmental pollutants, $\mathrm{CO}_{2}$ reduction, sterilization, and synthesis of composite capacitor materials [139,141-149].

The forbidden band width of semiconductors is an important factor limiting the wide application of photocatalysts.; as such, the forbidden band widths of some commonly used photocatalysts are summarized in Table 2.

Table 2. Band gaps of common photocatalysts.

\begin{tabular}{|c|c|c|c|c|c|}
\hline \multirow{2}{*}{ Semiconductor } & \multirow{2}{*}{ Crystal Structure } & \multicolumn{3}{|c|}{ Band Gap Structure $(\mathrm{PH}=7)$} & \multirow{2}{*}{ Reference } \\
\hline & & CB & VB & $\mathrm{E}_{\mathrm{g}} / \mathrm{eV}$ & \\
\hline $\mathrm{TiO}_{2}$ & Anatase & -0.50 & 2.70 & 3.20 & [149] \\
\hline $\mathrm{ZnO}$ & & -0.31 & 2.89 & 3.20 & [150] \\
\hline $\mathrm{CuO}$ & & -1.16 & 0.85 & 2.00 & [151] \\
\hline CdS & & -0.90 & 1.50 & 2.40 & [152] \\
\hline $\mathrm{ZnS}$ & & -1.04 & 2.56 & 3.60 & [101] \\
\hline $\mathrm{g}-\mathrm{C}_{3} \mathrm{~N}_{4}$ & & -1.30 & 1.40 & 2.70 & {$[139,153]$} \\
\hline $\mathrm{g}-\mathrm{C}_{3} \mathrm{~N}_{4}$ & & -1.53 & 1.16 & 2.70 & {$[154]^{a}$} \\
\hline $\mathrm{Ta}_{3} \mathrm{~N}_{5}$ & & -0.75 & 1.35 & 2.10 & [155] \\
\hline $\mathrm{TaON}$ & & -0.75 & 1.75 & 2.50 & [156] \\
\hline $\mathrm{Fe}_{2} \mathrm{O}_{3}$ & & 0.28 & 2.48 & 2.20 & [157] \\
\hline $\mathrm{Bi}_{2} \mathrm{O}_{3}$ & & 0.33 & 3.13 & 2.80 & [158] \\
\hline $\mathrm{BiVO}_{4}$ & & -0.30 & 2.10 & 2.40 & [159] \\
\hline $\mathrm{WO}_{3}$ & & -0.10 & 2.70 & 2.80 & [160] \\
\hline $\mathrm{Ag}_{3} \mathrm{PO}_{4}$ & Cubic & 0.04 & 2.49 & 2.45 & [161] \\
\hline
\end{tabular}

${ }^{a}$ Measurement by the valence band X-ray photoelectron spectroscopy (VB XPS) spectrum.

\section{Common Preparation Methods}

There are many ways to prepare a photocatalyst. In this review, we divide these methods into the electrospinning method, the solid phase method, the liquid phase method, and the vapor phase method.

Next, we will describe the preparation method of a photocatalyst in detail according to the structure of Figure 3.

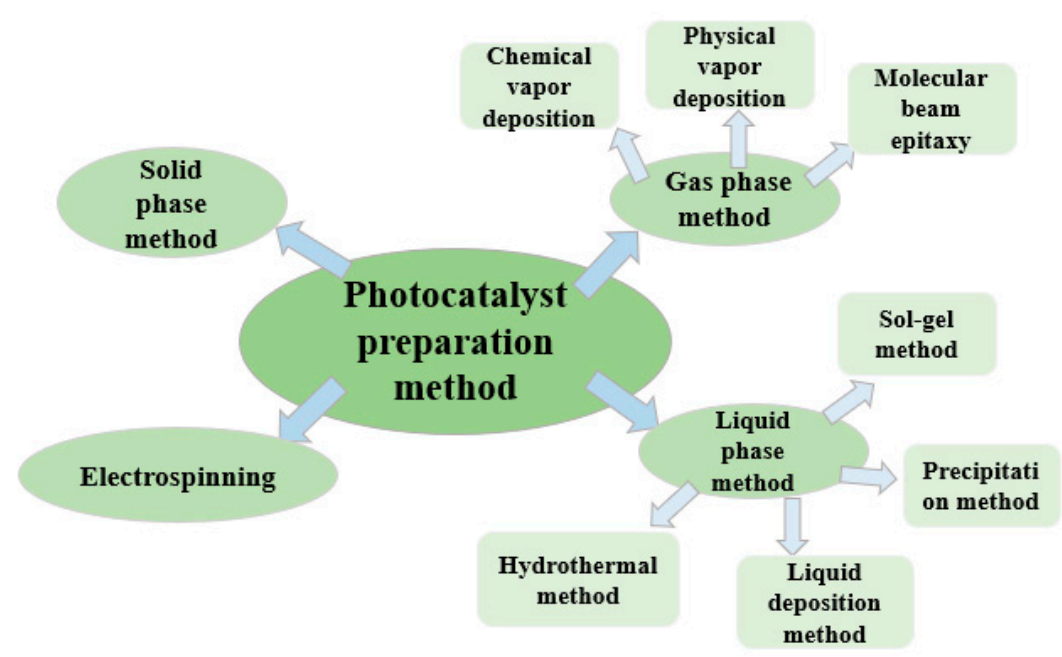

Figure 3. Photocatalyst preparation method.

\subsection{Electrospinning}

Electrospinning technology is a method of directly producing polymer nanofibers [161-177]. Electrospinning techniques have the advantages of simple manufacturing equipment, low spinning 
cost, a wide variety of spinnable materials, and a controllable process. Electrospinning technology is one of the major methods for effectively preparing nanofiber materials. Electrospinning technology has been used to produce various nanofibers including organic, organic/inorganic composites, and inorganic nanofibers.

Electrospinning device mainly consists of a high-voltage power supply, a nozzle and liquid supply device, and a fiber receiving device, as shown in Figure 4A. High voltage power supplies typically use a DC power supply that can generate thousands to tens of thousands of volts. The function of the high voltage power supply is to generate a high voltage electric field so that the liquid becomes charged and polarized, eventually forming a jet. The liquid supply device is a container (such as a syringe) having a capillary at one end, and the container is filled with a polymer solution or melt. In addition, as experimental requirements have increased, many experiments have gradually adopted liquid flow control systems that allow for a more accurate control of liquid flow. The fiber receiving device is a metal receiving plate at the opposite end of the nozzle and may be a rotating roller or an aluminum foil layer on the plane of the metal plate. The receiving device is grounded with a wire and connected to the negative electrode of the high voltage power source.
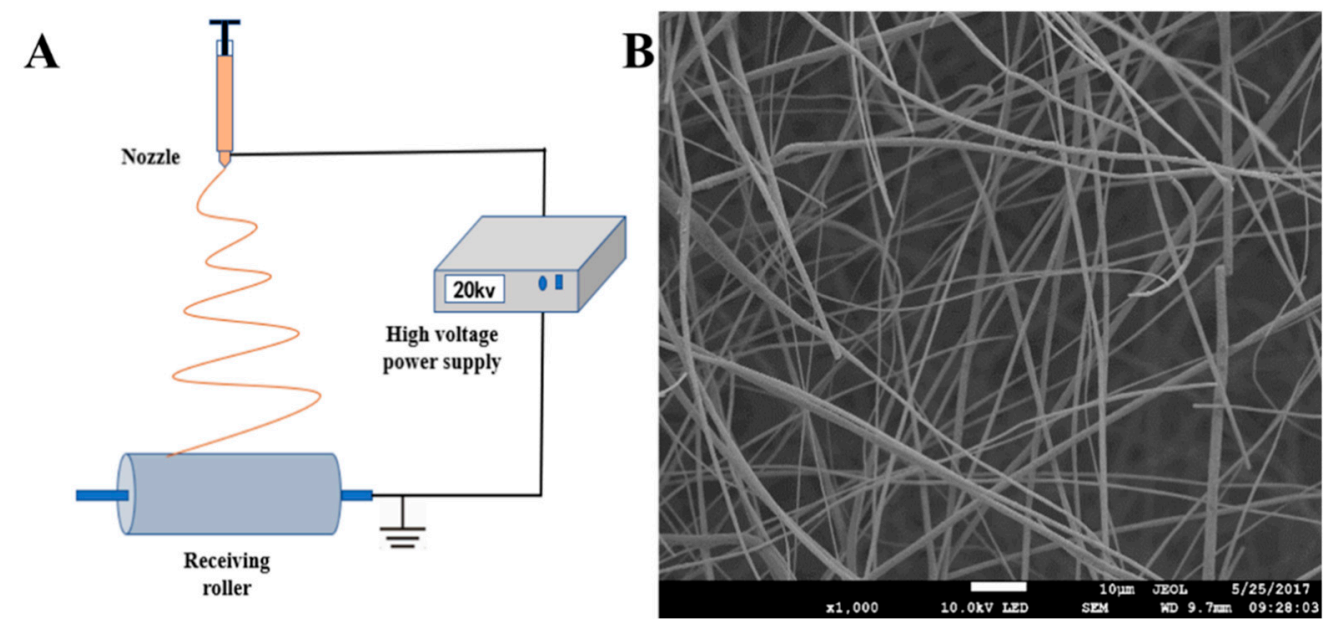

Figure 4. (A) Schematic illustration of electrospinning and (B) $\mathrm{SEM}$ image of $\mathrm{TiO}_{2}$ nanofibers prepared by electrospinning.

During electrospinning, the high voltage electric field melts and deforms the polymer solution, which then forms conical droplets that protrude at the end of the showerhead. When the repulsive force of the surface of the droplet exceeds the surface tension, a minute jet ejects from the surface of the droplet. These jets undergo a high-speed stretching of electric field force at short distances, the solvent volatilizes and solidifies, and, finally, it deposits on the receiving plate to form polymer fibers. Figure $4 \mathrm{~B}$ shows an SEM image of a polyvinylidene fluoride (PVDF) $/ \mathrm{TiO}_{2}$ fiber film prepared by an electrospinning method. We can observe that the nanofiber membrane prepared by electrospinning has a porous structure. The conventional fiber has a specific surface area of $0.4 \mathrm{~m}^{2} \mathrm{~g}^{-1}$, as compared with a conventional fiber membrane, and the electrospinning fiber has a specific surface area of about $40 \mathrm{~m}^{2} \mathrm{~g}^{-1}$ [163]. The electrospinning fiber membrane has a large specific surface area, which can effectively solve the disadvantage that the specific surface area of the photocatalyst is small. In addition, the prepared fiber membrane is advantageous for the recovery of the photocatalyst and the reduction of secondary pollution.

In the process of manufacturing nanofibers by electrospinning, the voltage, solution viscosity, surface tension, solvent evaporation rate, and conductivity of the electrospinning operation are numerous, and their relationship is complex. These factors all affect the average diameter and uniformity of the fiber to different extents. 


\subsection{Solid Phase Method}

The solid phase method is a method in which a reaction raw material is thoroughly mixed and ground at a certain stoichiometric ratio before being calcined at a specific temperature to obtain a product [178-182]. The solid phase method has the advantages of a simple apparatus, convenient operation, low cost, uniform particle size, and controllable force. In the solid phase method, no solvent is required; thus, hard agglomeration, which may occur in the liquid phase, can be avoided, and environmental pollution can be reduced. However, the solid phase method also has the disadvantage that the particles are easy to aggregate, the powder is not fine enough, the impurities are easily mixed, and the oxidation of the ions is easy.

\subsection{Gas Phase Method}

The gas-phase method refers to direct use of gas or a means to change a substance into a gas-making it physically or chemically react in a gas state-to agglomerate and grow to form nanoparticles in the cooling process. In the gas phase method, nanoparticles having high purity, and good nanoparticle properties can be produced. However, the gas phase method also requires advanced techniques and equipment. Vapor phase methods include physical vapor deposition (PVD), chemical vapor deposition (CVD), and molecular beam epitaxy (MBE).

\subsubsection{Chemical Vapor Deposition (CVD)}

Chemical vapor deposition (CVD) $[183,184]$ is a method of forming a thin film by chemical reaction to one or more vapor phase elements or compounds on the surface of a substrate. CVD can be used to deposit metals, carbides, nitrides, oxides, borides, and the like. CVD can be applied to the surfaces of complex geometric shapes and has a good adhesion to the film base. Therefore, the development of CVD is very rapid. Depending on different reactants and control conditions, CVD can be further divided into atmospheric pressure chemical vapor deposition, low pressure chemical vapor deposition, plasma CVD, laser CVD, and metal-organic CVD. Thanks to the development of thin film manufacturing technology, CVD has been continuously developed and improved. However, the equipment and cost required for CVD is relatively high. In addition, CVD possesses many disadvantages, such as uneven microscopic surface roughness of the resulting film and particle size $(50-150 \mathrm{~nm})$, as well as a relatively large surface roughness of the film.

\subsubsection{Physical Vapor Deposition (PVD)}

Physical vapor deposition (PVD) is a method in which a paint is vaporized by a physical method to form a film on the substrate surface. In addition to conventional vacuum deposition and sputter deposition techniques, PVD includes various ion beam deposition, ion plating, and ion beam assisted deposition techniques that have prospered in recent years. Types of deposition include vacuum deposition, sputtering, and ion plating [185-188]. PVD is a common technique for producing hard coatings (hard films). Compared with CVD, the PVD method has a low deposition temperature and does not easily cause deformation and cracking of the substrate. Films produced by PVD are uniform and possess easy to control structures and properties. However, the PVD preparation of the film must be carried out under a vacuum, and the equipment necessary for film formation is expensive.

To date, PVD methods can deposit not only alloy films and metal films but also ceramics, compounds, polymer films, semiconductors, and so on.

\subsubsection{Molecular Beam Epitaxy (MBE)}

Molecular beam epitaxy (MBE) is a newly developed method of film production and is also a special vacuum coating process. MBE is a new manufacturing technology for single crystal films [189-193]. MBE means to spray a hot atomic beam or molecular beam onto the surface of a heated substrate under vacuum conditions and react with the surface of the substrate to deposit the film. 
The advantages of MBE include the facts that the beam intensity is easy to control precisely, the surface morphology of the epitaxial material can be made into a multi-layer structure of different compositions, and the composition and doping of the epitaxial layer can be changed at will. MBE can accurately control the thickness of the epitaxial layer, the doping profile of the heterojunction interface, and the flatness of the heterojunction interface, which is beneficial for improving the purity and integrity of the epitaxial layer. MBE has made it possible to control the precise growth of atomic layers and subsequent atomic layers. MBE can produce thin monocrystalline thin films on the order of tens of atomic layers and can also produce thin films with different doping and different compositions.

\subsection{Liquid Phase Method}

The liquid phase method is also called a wet chemical method. In the liquid phase method, it is necessary to first select an appropriate soluble metal salt and then prepare a solution according to the composition of the prepared material [194-196]. Second, suitable precipitating agents are selected to precipitate or crystallize the metal ions in the solution; they may also operate by evaporation, sublimation, hydrolysis, etc. to cause precipitation or crystallization. Finally, the precipitate or crystal is dehydrated or thermally decomposed to obtain the desired raw material powder.

There are many methods for preparing photocatalytic films by liquid-phase method, such as the sol-gel method, the precipitation method, the liquid deposition method, and the hydrothermal method.

\subsubsection{Sol-Gel Method}

The sol-gel method is a wet chemical approach used to prepare nanoparticles [197]. In the sol-gel method, a precursor is dissolved in a solvent, and a sol is formed through hydrolysis or alcoholysis. The sol is then converted into a gel after prolonged storage or drying. Figure 5 shows the process of preparing nanomaterials by a sol-gel method.

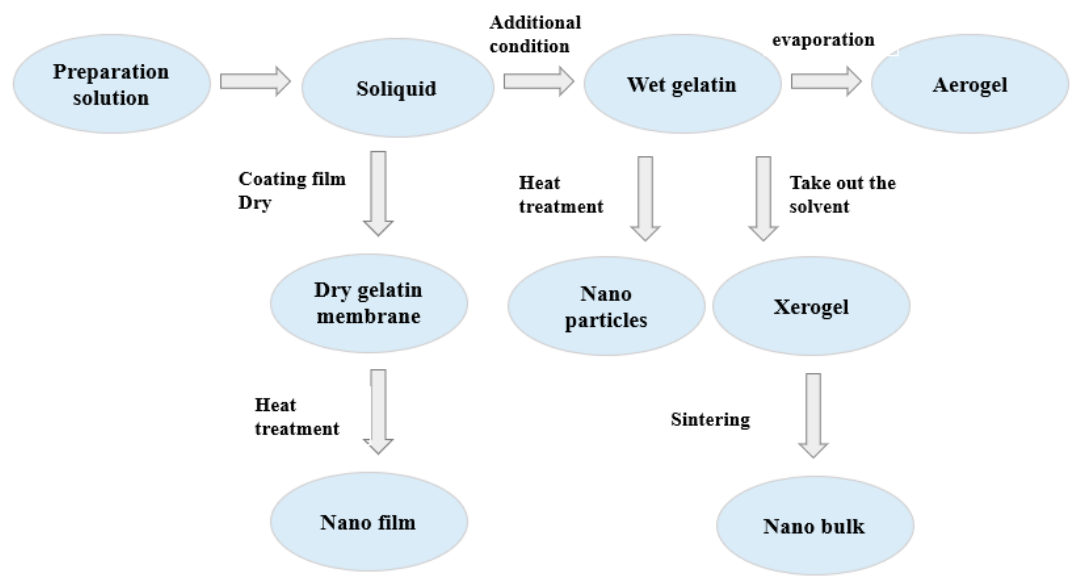

Figure 5. Nanofilm or nanoparticles by a sol-gel method.

Among the nanoparticles prepared by the sol-gel method, the most important factors are the formation of the sol and gel. There are many complicated parameters affecting the sol-gel process. At present, most people think that the four main parameters have important influence on the sol-gel process. These are the $\mathrm{pH}$ of the solution, the concentration of the solution, the reaction temperature, and the reaction time.

The sol-gel process has the advantages of high purity, high uniformity, low synthesis temperature, and easy control of the reaction conditions [198-200]. The preparation process of the sol-gel process is relatively simple and does not require special or expensive equipment. The problem of the sol-gel method is that the raw material is generally titanium alkoxide, a large amount of organic solvent is required, and the obtained film is heat-treated at a relatively high temperature. Therefore, the film forming cost is relatively high, the adhesion of the film is poor, and the transparency is poor. 


\subsubsection{Precipitation Method}

The precipitation method is one of the most common methods for synthesizing nanomaterials. In the precipitation method, substances with different chemical components are mixed, and a precipitant is added to obtain a precursor precipitate. The precursor precipitate is then dried or calcined to produce the corresponding nanoparticles [201-206]. When the particle diameter is about $1 \mu \mathrm{m}$, a precipitate is formed. The particle size of the particles generally depends on the solubility of the precipitate and the supersaturation degree of the solution. The smaller the solubility of the precipitate is, the smaller the diameter of the particle produces, and the smaller the supersaturation degree of the solution is, the larger the diameter of the particle forms.

The photocatalyst prepared by the precipitation method has good light absorption capability and can promote the separation of holes, and it can thereby improve photocatalytic performance. In the precipitation process, many of the heavy metals added do not readily react in solution and may introduce impurities into the solution, which limits the application of the precipitation method. During the operation of the precipitation method, the reaction temperature, time, $\mathrm{pH}$ value, ratio of reactants, titration rate, and other factors have a certain influence on the material preparation. The precipitation method shows the characteristics of low cost, simple process, and safety.

\subsubsection{Liquid Deposition Method}

In the liquid deposition method, a substrate is immersed in an appropriate reaction solution, and a uniform and dense film is deposited onto the substrate. These films obtained by the liquid deposition process usually consist of oxides or hydroxides [207-211]. The liquid deposition method is suitable for substrates of various shapes, and it does not require a high temperature during film formation or expensive equipment. The liquid deposition method can be used not only to prepare a single oxide film but also to prepare a composite oxide film, a multi-component oxide film, a metal fine-particle-dispersed oxide film, a laminated oxide film, and so on. The reaction principle of liquid deposition method is not complicated. The process is simple, and the film formation rate is high. The benefit/cost ratio is large, while the pollution to the environment is small. In addition, several disadvantages of liquid deposition methods have been solved, which means that liquid deposition methods have wide application prospects.

For example, Zhou et al. [212-214] immersed a substrate glass sheet in a reaction solution to obtain a transparent anatase type $\mathrm{TiO}_{2}$ film at $35{ }^{\circ} \mathrm{C}$. The reaction solution containing a complex $\mathrm{TiF}_{6}{ }^{2-}$, $\mathrm{F}^{-}$ion trapping agent $\mathrm{H}_{3} \mathrm{BO}_{3}$ and a crystallization-inducing agent of $\mathrm{TiO}_{2}$. The thickness of the film obtained by the liquid phase deposition method increases as the deposition time increases, and when the deposition time is $9 \mathrm{~h}$, the resulting film thickness is about $260 \mathrm{~nm}$. The photocatalytic activity of $\mathrm{TiO}_{2}$ thin film after heat treatment at different temperatures was evaluated by the photocatalytic degradation of a methylene blue experiment. The results showed that the $\mathrm{TiO}_{2}$ film heated at $300{ }^{\circ} \mathrm{C}$ has the highest photocatalytic activity, and its activity is equivalent to five times that of $\mathrm{TiO}_{2}$ film deposited at $35^{\circ} \mathrm{C}$.

\subsubsection{Hydrothermal Method}

In the hydrothermal method, an inorganic or organic compound is mixed with water at a temperature of $100-350^{\circ} \mathrm{C}$ and a high pressure, and then an improved inorganic substance is obtained through several steps. The resulting inorganic substance is filtered, washed, and dried to obtain ultrafine particles of high purity $[7,215-220]$.

The hydrothermal preparation of the film is carried out in the liquid phase, and no post treatment is required. This feature of the hydrothermal method avoids defects such as curl, cracks, particle coarsening, and film-to-gas reactions that can occur during heat treatment of the film. The hydrothermal method uses an inorganic substance as the precursor and water as the reaction medium, which avoids a series of disadvantages resulting from the use of organometallic materials. The hydrothermal method 
has many advantages, including mild conditions, a stable system, little environmental pollution, an easy process, and a low cost. In addition, films prepared by the hydrothermal method have good uniformity, firmly adhere to the substrate, and are not limited by the shape and size of the substrate [221]. The hydrothermal method can also achieve uniform doping and preparation of the nanocomposite by adjusting the proportion of the product or by adding a surfactant.

\section{Methods for Improving Photocatalytic Efficiency}

By investigating the mechanism of photocatalytic reaction, it is known that semiconductor photocatalysis shows the advantages of mild reaction conditions, high efficiency, and a wide application range. However, semiconductor photocatalytic reactions also suffer from drawbacks in practical applications such as narrow absorption spectra, low photon quantum efficiency, and an easy recombination of photogenerated holes. The recombination of photogenerated electrons and holes is unfavorable for photocatalytic reactions. Therefore, reducing the recombination of photogenerated electrons and holes is an effective way to improve photocatalytic efficiency $[48,222,223]$. Many methods have been reported for improving the photocatalytic efficiency of semiconductors such as precious metal deposition, semiconductor compounds, metal or non-metal particle doping, and surface dye sensitization.

\subsection{Precious Metal Depositing}

Precious metal deposition on semiconductor surfaces considered to be an effective way of capturing excited electrons. The basic principle of precious metal deposition on a semiconductor surface is as follows. When the noble metal and the semiconductor are in contact, the work function of the metal is larger than the work function of the semiconductor, so the electron continuously moves from the semiconductor to the metal until the energy levels of both are equal. Thus, the metal surface and the semiconductor surface each obtain excessive negative and positive charges, causing band bending near the interface where the semiconductor is in contact with the metal, thereby forming a Schottky barrier. The Schottky barrier can capture photogenerated electrons at the surface of the semiconductor and suppress the recombination of electron-hole pairs [224], thereby improving photocatalytic efficiency.

Among the surface precious metal deposits, the most commonly used metal is the Pt of Group VIII [225-232]. In addition to Pt, noble metals such as Ag [233-238], Ru [239,240], Pd [241-245], and $\mathrm{Au}$ [246-250] are also used to improve the photocatalytic performance of semiconductors. However, the major disadvantage of precious metals such as $\mathrm{Ag}, \mathrm{Ru}, \mathrm{Pd}$, and $\mathrm{Au}$ is that the price is relatively high and not suitable for large scale applications [251-257].

Take $\mathrm{TiO}_{2}$ as an example. Due to the large ionic radius of the noble metal, it is impossible to enter the $\mathrm{TiO}_{2}$ lattice. Therefore, in order to improve the photocatalytic performance of $\mathrm{TiO}_{2}$, it is possible to change the surface characteristics of $\mathrm{TiO}_{2}$ by depositing a noble metal on the surface of $\mathrm{TiO}_{2}$ photocatalyst [258-261]. The surface modification of a noble metal to $\mathrm{TiO}_{2}$ photocatalyst is achieved by changing the electron distribution [261]. When $\mathrm{TiO}_{2}$ contacts the noble metal, carriers are redistributed, and a space charge layer is formed on the surface of the $\mathrm{TiO}_{2}$ close to the metal particle interface. The space charge layer facilitates the transfer of photogenerated electrons to the interface between the noble metal and $\mathrm{TiO}_{2}[258,259,262]$, thereby suppressing the recombination of photogenerated electrons and holes, improving photocatalytic efficiency.

Klein et al. [263] deposited single atom and diatomic clusters ( $\mathrm{Pd}, \mathrm{Pt}, \mathrm{Ag} / \mathrm{Pd}, \mathrm{Ag} / \mathrm{Pt}$, and $\mathrm{Pd} / \mathrm{Pt})$ on the surface of $\mathrm{TiO}_{2}$ (P25) using a high energy radiation reduction method. By the photocatalytic decomposition of toluene, it was found that palladium/platinum-titanium dioxide $\left(\mathrm{Pd} / \mathrm{Pt}-\mathrm{TiO}_{2}\right)$ has the strongest decomposing ability for toluene in the ultraviolet and visible range. Two methods in Klein's experiment are shown in Figure 6. In the comparison of different preparation methods, it was found that the sample prepared by the one-step method had the highest degradation ability to phenol in the visible range. Zhang et al. [264] deposited Au nanoparticles on the surface of sulfated $\mathrm{TiO}_{2}$. Au nanoparticles have excellent electron trapping ability and can effectively prolong the 
lifetime of electron-hole pairs. In the photocatalyst experiment, under the condition of $\mathrm{pH}=6.5$, the decomposition rate of the photocatalyst to Congo red dye can reach $97.6 \%$. Padilla et al. [265] used an innovative sonic degradation deposition method to deposit a series of noble metals on the surface of $\mathrm{TiO}_{2}$ within 10-20 s. These precious metals include single or complex noble metals such as $\mathrm{Au}, \mathrm{Cu}$, $\mathrm{Pd}, \mathrm{Pt}, \mathrm{Au}-\mathrm{Pd}, \mathrm{Au}-\mathrm{Cu}, \mathrm{Au}-\mathrm{Fe}, \mathrm{Au}-\mathrm{Co}, \mathrm{Au}-\mathrm{Pt}-\mathrm{Au}-\mathrm{Rh}$, and $\mathrm{Au}-\mathrm{Ru}$. In photocatalytic experiments under room temperature and visible light conditions, the decomposition rate of methyl orange dye was highest with the $\mathrm{AuPd} / \mathrm{TiO}_{2}$ (mass ratio of $\mathrm{Au}$ : $\mathrm{Pd}$ is 3:1) catalyst.
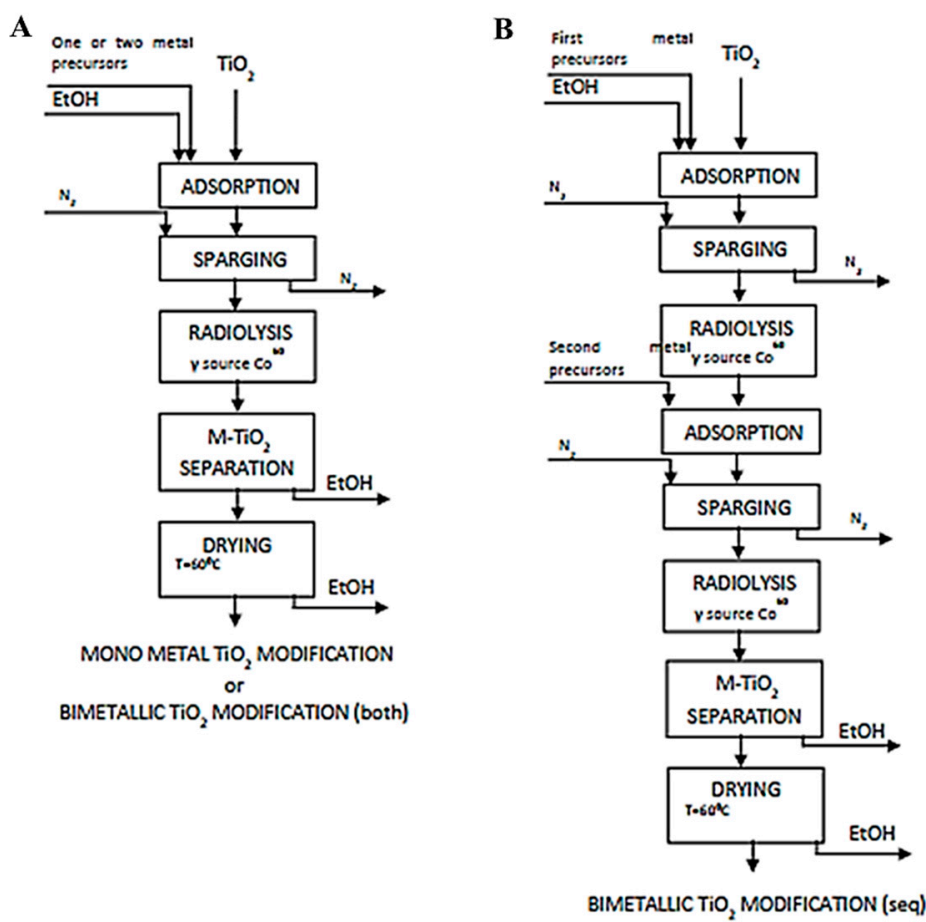

Figure 6. Block diagram of (A) mono metal or bimetallic (both) $\mathrm{TiO}_{2}$ modification and (B) bimetallic $\mathrm{TiO}_{2}$ modification (seq) [263].

Most precious metals are toxic, expensive, and not suitable for a wide range of applications. Relatively speaking, Ag is one of the most popular precious metals because it is less toxic and not expensive. Jaafar et al. [266] applied a mild in situ electrochemical method to deposit Ag nanoparticles on the surface of $\mathrm{TiO}_{2}$. A photocatalytic decomposition experiment of chlorophenol was carried out using the prepared catalyst under the condition of $\mathrm{pH}=5$. After $6 \mathrm{~h}$ of photocatalytic decomposition, the decomposition rate of the $\mathrm{Ag}-\mathrm{TiO}_{2}$ photocatalyst was $94 \%$, much higher than that of the other photocatalysts. Though the silver-oxygen-titanium (Ag-O-Ti) chemical bond will reduce the catalytic activity of the material to some extent, the proper content of Ag and the oxygen vacancies on the surface of the material can effectively prevent the recombination of electron-hole pairs, thereby improving the photocatalytic efficiency of the photocatalyst.

\subsection{Semiconductor Compound}

A semiconductor composite photocatalyst is realized by two types of band-matched semiconductors. The methods for achieving semiconductor recombination include simple combinations, doping, multilayer structure, and out of phase combination. The essence of semiconductor blending to improve the photocatalytic performance is that photogenerated electrons or holes generated by a semiconductor move to the conduction band or the valence band of another semiconductor to separate photogenerated electrons and holes, thus effectively suppressing the recombination of carriers [252].

Arabzadeh et al. [267] combined a single-dimensional cadmium sulfide (CdS) nanowire with a $\mathrm{TiO}_{2}$ nanoparticle by a hot solvent method to form a catalyst for a core-shell structure. In photocatalysis 
experiments, cadmium sulfide/titanium dioxide $\left(\mathrm{CdS} / \mathrm{TiO}_{2}\right)$ photocatalysts can completely decompose methyl orange, methylene blue, and rhodamine $\mathrm{B}$, and the photocatalytic decomposition time is only 2-3 min. Wu et al. [268] prepared a nanorod $\mathrm{FeVO}_{4}-\mathrm{TiO}_{2}$ composite catalyst by the coprecipitation method. In the $\mathrm{NO}$ gas conversion experiment, the decomposition rate of $\mathrm{NO}$ by the nanorod $\mathrm{FeVO}_{4}-\mathrm{TiO}_{2}$ composite catalyst was more than 1.5 times that of the nanoparticle $\mathrm{FeVO}_{4}-\mathrm{TiO}_{2}$ composite catalyst. Chu et al. [269] prepared a $\mathrm{MoSe}_{2}-\mathrm{TiO}_{2}$ composite photocatalyst by using a hot solvent method. $\mathrm{Cr}^{6+}$ ions were reduced by using pure $\mathrm{MoSe}_{2}$, pure $\mathrm{TiO}_{2}$, and complex $\mathrm{MoSe}_{2}-\mathrm{TiO}_{2}$ as the photocatalysts. After $120 \mathrm{~min}$ of visible light irradiation, the reduction rate of $\mathrm{Cr}^{6+}$ by pure $\mathrm{MoSe}_{2}$ and pure $\mathrm{TiO}_{2}$ was only $61 \%$ and $2 \%$, respectively, while the conversion rate of composite catalyst $\mathrm{MoSe}_{2}-\mathrm{TiO}_{2}$ was as high as $91 \%$. Das et al. [270] prepared a zirconium dioxide-titanium dioxide $\left(\mathrm{ZrO}_{2}-\mathrm{TiO}_{2}\right)$ composite semiconductor photocatalyst by the sol-gel method. In the research of industrial printing and dyeing wastewater purification, there is a relationship between the degradation rate of pollutants and the radiation time, $\mathrm{pH}$, sewage concentration, and catalyst concentration. The concentration of organic pollutants, especially, has the greatest influence on the degradation rate of pollutants.

Shen et al. [271,272] reported the use of wet chemical methods to synthesize large-sized porous $\mathrm{InVO}_{4}$ spheroids and large-sized porous g- $\mathrm{C}_{3} \mathrm{~N}_{4}$ particles. Next, nano-TiO $\mathrm{O}_{2}$ particles were composited on the surfaces of $\mathrm{InVO}_{4}$ and $\mathrm{g}-\mathrm{C}_{3} \mathrm{~N}_{4}$ to obtain a semiconductor composite material having a large size, porosity, and narrow band gap. Experiments show that, in addition to improving the quantum effect of the material, the semiconductor composite material also increases the specific surface area of the material. Higher specific surface areas provide more reactive sites, thereby extending the lifetime of photogenerated electron-hole pairs.

In multicomponent modified $\mathrm{TiO}_{2}$, as compared to one-component modified $\mathrm{TiO}_{2}$, different components can be combined with one another such that the catalyst has different degrees of improvement in light absorption performance and electron-hole separation efficiency. Gao et al. [273] used photoreduction deposition and chemical bath deposition to prepare $\mathrm{Pt}$ and $\mathrm{CdS}$ nanoparticles on co-modified $\mathrm{TiO}_{2}$ nanotubes. The decomposition rate of methyl orange dye with $\mathrm{Pt}$ and $\mathrm{CdS}$ co-modified $\mathrm{TiO}_{2}$ nanotubes reached $91.9 \%$ under visible light. The decomposition rate of methyl orange fueled by a pure $\mathrm{TiO}_{2}, \mathrm{Pt} / \mathrm{TiO}_{2}$, and $\mathrm{CdS} / \mathrm{TiO}_{2}$ single composite catalyst is much lower than 91.9\%. Experimental results showed that $\mathrm{CdS}$ and $\mathrm{Pt}$ have a synergistic effect in which CdS can attract holes to form an active center and $\mathrm{Pt}$ can promote photogenerated electron transfer. Therefore, $\mathrm{TiO}_{2}$ co-doped with CdS and Pt has a significant improvement in photon capture rate and carrier separation efficiency. Feng et al. [274] used a hydrothermal method to prepare a multilayer semiconductor composite $\mathrm{TiO}_{2}$ nanotube array. Under the irradiation of solar light, the composite $\mathrm{TiO}_{2}$ nanotube can completely degrade p-nitrophenol and rhodamine B in $20 \mathrm{~min}$ and $80 \mathrm{~min}$, respectively.

\subsection{Metal or Non-Metal Ion Doping}

The introduction of impurity in the forbidden band by ion doping is one of the most common and effective methods for improving semiconductor performance. As early as 1982, Borgarello [275] mixed chromium ions $\left(\mathrm{Cr}^{5+}\right)$ into $\mathrm{TiO}_{2}$ to realize visible light cracking water. On one hand, ion doping can increase the concentration of semiconductor carriers, but, on the other hand, it is possible to form ion traps to capture electrons and holes and reduce the recombination of electron-hole pairs. Ion doping causes the red shift of the $\mathrm{TiO}_{2}$ photocatalyst, and the photo response of the photocatalyst can be extended to the visible region. According to the types of doped ions, ion doping can be classified into metal ion doping, non-metal ion doping, and metal/non-metal ion simultaneous doping.

\subsubsection{Metal Ion Doping}

Metal ion doping is the most commonly used method for photocatalyst modification. The metal ion doping method is to dope transition metal ions in the catalyst by high-temperature firing or auxiliary deposition. The influence of metal ion doping on the photocatalyst mainly includes the 
suppression of recombination of photogenerated electrons and holes, as well as the expansion of the response spectrum range of the photocatalyst. By doping $\mathrm{TiO}_{2}$ with chromium and vanadium ions, the excitation wavelength range of $\mathrm{TiO}_{2}$ can be expanded to the visible light region (to the vicinity of $600 \mathrm{~nm}$ ). However, the incorporation of metal ions sometimes becomes the recombination center of electrons and holes, affecting the photocatalytic effect. The type and concentration of doping ions are different, and the influence on the photocatalysis experiment also differs. Experimentally doped metal ions include transition metal ions and rare earth metal ions.

Transition metal ions mainly include cobalt ions $\left(\mathrm{Co}^{2+}\right)$, iron ions $\left(\mathrm{Fe}^{3+}\right)$, and copper ions $\left(\mathrm{Cu}^{2+}\right)$. Different metal ion doping shows different effects on the performance of a photocatalyst. Doping some specific metal ions can improve the photon efficiency, such as $\mathrm{Fe}^{3+}$ [255], while doping some other metal ions, such as $\mathrm{Cr}^{3+}$, is harmful [253]. Choi et al. [276] studied more than 20 metal ion doped $\mathrm{TiO}_{2}$ nanocrystals and found that doping $0.5 \mathrm{wt} \%$ of $\mathrm{Fe}^{3+}, \mathrm{Ru}^{2+}, \mathrm{Mo}^{5+}, \mathrm{Re}^{2+}, \mathrm{Os}^{2+}, \mathrm{V}^{5+}$, and $\mathrm{Rh}^{2+}$ in the crystal lattice can increases the photocatalytic activity of photocatalyst. Wang et al. [277] applied a simple hydrothermal method to prepare $\mathrm{Fe}^{3+}$ doped $\mathrm{TiO}_{2}$ nanotube array catalysts. The semiconductor catalyst prepared at a concentration of $\mathrm{Fe}^{3+}$ of $1 \mathrm{mmol} / \mathrm{L}$ showed good catalytic performance under irradiation with a solar lamp. The time required for the $\mathrm{Fe}^{3+}$ doped semiconductor catalyst to decompose $98.79 \%$ methyl blue is only $120 \mathrm{~min}$. The reduction ratio of $\mathrm{Cr}^{6+}$ by the $\mathrm{Fe}^{3+}$-doped semiconductor catalyst is as high as $83.79 \%$, which is much higher than the reduction ratio of pure $\mathrm{TiO}_{2}$ to $\mathrm{Cr}^{6+}(39.6 \%)$. Inturi et al. [278] produced $\mathrm{Cr}^{3+}$ doped $\mathrm{TiO}_{2}$ nanoparticle photocatalysts by three preparation methods and found that the doping samples prepared by flame spraying method have higher catalytic performance than other preparation methods. The sample prepared by the flame spray method degraded chlorophenol under visible light, and the decomposition rate reached $61 \%$ in just $5 \mathrm{~h}$. Nanoparticles prepared by the flame spray method have a high specific surface area and increase the active site of the complex, thereby improving its photocatalytic efficiency. Ma et al. [279] used a co-precipitation method to prepare $\mathrm{Mg}$, $\mathrm{Zn}$, and $\mathrm{Cr}$-three kinds of ion co-doped $\mathrm{TiO}_{2}$ nano-catalysts - and used them to degrade Congo red dye. Experimental results showed that the $\mathrm{MgZnCr}-\mathrm{TiO}_{2}$ catalyst has good catalytic performance in the visible range. The $\mathrm{MgZnCr}-\mathrm{TiO}_{2}$ sample has recyclability and maintains a stable photocatalytic performance after five cycles.

Rare earth elements were originally used as surface treatment agents for $\mathrm{TiO}_{2}$ to improve the vividness of $\mathrm{TiO}_{2}$. With the rapid development of photocatalysts, the role of rare earth elements becomes more important. Rare earth metal ions have a special electronic layer structure compared to transition metal ions. In addition to the benefits of doped transition metals, the doping of rare earth metal ions can also cause semiconductor lattice distortion and impurity defects, form traps for electron holes, and enhance the quantum effect of the semiconductor catalyst. Villabonaleal et al. [280] analyzed the catalytic properties of Lanthanum (La), Cerium (Ce), Praseodymium (Pr), Neodymium $(\mathrm{Nd})$, Samarium $(\mathrm{Sm})$, Europium $(\mathrm{Eu})$, and Gadolinium $(\mathrm{Gd})$ rare earth doped $\mathrm{TiO}_{2}$. They found that the atomic number and concentration of the lanthanide influence the band gap energy and the specific surface area of the catalyst but have little influence on visible light absorption. Malengreaux et al. [281] prepared $\mathrm{TiO}_{2}$ semiconductor photocatalysts with $\mathrm{Fe}^{3+}, \mathrm{Cr}^{3+}, \mathrm{La}^{3+}$, and $\mathrm{Eu}^{3+}$ ions doped and co-doped by a sol-gel method. In the experiment of decomposing p-nitrophenol under ultraviolet and visible light, the $\mathrm{La}-\mathrm{Fe}-\mathrm{TiO}_{2}$ catalyst showed better photocatalytic ability than the other samples.

\subsubsection{Non-Metal Ion Doping}

The doping of many metals such as $\mathrm{V}^{3+}, \mathrm{V}^{4+}, \mathrm{Cr}^{3+}, \mathrm{Mn}^{3+}, \mathrm{Fe}^{3+}, \mathrm{Co}^{3+}, \mathrm{Ni}^{2+}, \mathrm{Zn}^{2+}, \mathrm{Ga}^{3+}, \mathrm{Zr}^{4+}$, and $\mathrm{Nb}^{5+}$ can expand the spectral response range of $\mathrm{TiO}_{2}$ to the visible region [282,283]. In addition, some metal-doped $\mathrm{TiO}_{2}$ are not thermodynamically stable and easily cause an increase in recombination centers, thereby reducing the light absorption efficiency of $\mathrm{TiO}_{2}$. Many researchers have therefore chosen to dope $\mathrm{TiO}_{2}$ with non-metal atoms that form covalent bonds with titanium atoms [284]. In 2001, Japanese scientist Asahi et al. [285] prepared a $\mathrm{TiO}_{2-x} \mathrm{~N}_{x}$ photocatalyst using non-metallic N-doped $\mathrm{TiO}_{2}$. The $\mathrm{TiO}_{2-\mathrm{x}} \mathrm{N}_{\mathrm{x}}$ photocatalyst extends the optical excitation wavelength of $\mathrm{TiO}_{2}$ to the visible region 
of 400-520 nm (Figure 7A) and maintains the photocatalytic activity of $\mathrm{TiO}_{2}$ in the ultraviolet region. Methyl blue and acetaldehyde decomposition experiments showed that the $\mathrm{TiO}_{2-\mathrm{x}} \mathrm{N}_{\mathrm{x}}$ photocatalyst shows high photocatalytic activity under both ultraviolet and visible light (Figure 7B).
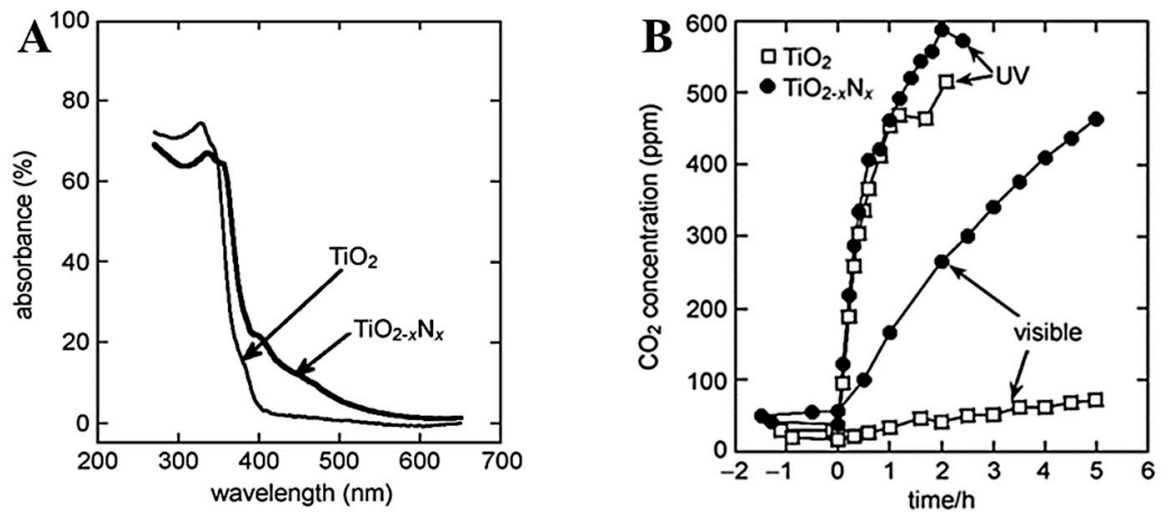

Figure 7. (A) UV-Vis spectra of $\mathrm{TiO}_{2-\mathrm{x}} \mathrm{N}_{\mathrm{x}}$ and $\mathrm{TiO}_{2}$ and (B) the photocatalytic property of acetaldehyde [285].

The research of $\mathrm{TiO}_{2}$ has opened a new research area on a non-metal doped modified $\mathrm{TiO}_{2}$ visible light catalyst, which is undoubtedly a pioneering work. Afterwards, scientists conducted systematic and detailed research on the doping modification of $\mathrm{TiO}_{2}$ photocatalyst with nonmetallic elements. Non-metals generally used for semiconductor doping are N [285-290], C [55,291-293], S [101,292,294-299], P [297,300,301], F [290,302-307], Cl [308], I [309], B [310-313], and Si [314-316], among others.

Kitano et al. [286] reported the preparation of $\mathrm{N}-\mathrm{TiO}_{2}$ films by the radio frequency (RF) magnetron sputtering (RF-MS) deposition method, in which an $\mathrm{N}_{2} / \mathrm{Ar}$ mixture was used as a sputtering gas. It was found that the absorption band of the $\mathrm{N}-\mathrm{TiO}_{2}$ photocatalyst was shifted to the visible region, and the catalytic performance of the $\mathrm{N}-\mathrm{TiO}_{2}$ photocatalyst under visible light was remarkably improved. Simsek et al. [317] described the use of a hot solvent method to prepare a boron (B) ion doped $\mathrm{TiO}_{2}$ catalyst, and they studied the effect of the boron doping amount and $\mathrm{pH}$ on the degradation of environmental pollutants. The experiment result shows the following: After UV irradiation for $300 \mathrm{~min}$, the decomposition rates of pure $\mathrm{TiO}_{2}$ and $\mathrm{B}-\mathrm{TiO}_{2}$ relative to dichlorophenol were $75.7 \%$ and $89.7 \%$, respectively, and the decomposition rates of bisphenol A were $97.3 \%$ and $99.1 \%$, respectively. After irradiation with visible light for $300 \mathrm{~min}$, the decomposition rates of pure $\mathrm{TiO}_{2}$ and $\mathrm{B}-\mathrm{TiO}_{2}$ relative to dichlorophenol were $20.2 \%$ and $75.1 \%$, respectively, and the decomposition rates of bisphenol A were $46.0 \%$ and $97.7 \%$, respectively. Since the forbidden band width of the B-doped $\mathrm{TiO}_{2}$ semiconductor decreases, the modified material has an absorption response in the visible light region. In addition, two chemical bonds of $\mathrm{B}-\mathrm{O}-\mathrm{Ti}$ and $\mathrm{B}-\mathrm{O}-\mathrm{B}$ are formed during the doping process, and these two chemical bonds not only provide stable performance but also function as traps of photogenerated electrons. He et al. [318] synthesized a C-doped $\mathrm{TiO}_{2}$ photocatalyst by the hydrothermal method. As a carbon source, chitosan forms a porous morphology of the composite $\mathrm{TiO}_{2}$, and a $\mathrm{Ti}-\mathrm{C}$ chemical bond in the complex that promotes formation of surface oxygen vacancies. The porous morphology of the composite $\mathrm{TiO}_{2}$ and the surface oxygen vacancies together improve the capture rate of organic molecules by the photocatalyst and improve the photocatalytic performance. The conversion rate of composite $\mathrm{TiO}_{2}$ under visible light to $\mathrm{NO}$ gas can reach $71 \%$.

Multi-component non-metal doping can also improve the catalytic ability of $\mathrm{TiO}_{2}$ to some extent. Elsheikh et al. [319] used a one-step hydrothermal method to synthesize $\mathrm{C}$ and $\mathrm{N}$ element co-doped $\mathrm{TiO}_{2}$ photocatalysts, and they used different molar concentrations of glycine to make the materials contain different proportions of brookite/anatase. Under visible light irradiation, the degradation rate of pure $\mathrm{TiO}_{2}$ to ibuprofen was only $11.1 \%$, but the degradation rate of $\mathrm{C}-\mathrm{N}-\mathrm{TiO}_{2}$ was $100 \%$. 
Zhang et al. [320] synthesized a $\mathrm{TiO}_{2}$ photocatalyst co-doped with fluorine and graphene oxide by the hydrothermal method. The decomposition rate of bromate by the complex $\mathrm{TiO}_{2}$ photocatalyst was found to exceed $90 \%$ after UV irradiation for $15 \mathrm{~min}$. The doping of fluoride ions can increase the number of high surface energy (001) crystal planes of $\mathrm{TiO}_{2}$, while doped graphene oxide gives $\mathrm{TiO}_{2}$ excellent conductivity and large specific surface area. Therefore, after introducing fluoride ions and graphene oxide, the transfer efficiency of photogenerated electrons can be effectively accelerated, and the photocatalytic efficiency can be improved.

\subsubsection{Mixed Doping}

Nonmetallic ions can also be used in combination with metal ions. Theoretically, the simultaneous doping of metal ions and non-metal ions can simultaneously obtain the advantages of metal ions and non-metal ions. Lei et al. [321] applied the hydrothermal method to prepare $\mathrm{Fe}, \mathrm{N}$, and C co-doped $\mathrm{TiO}_{2}$ photocatalysts. In the study of the reduction and degradation of a $\mathrm{Cr}^{6+}$ solution, the conversion of the $\mathrm{Fe}-\mathrm{N}-\mathrm{C}-\mathrm{TiO}_{2}$ catalyst reached $100 \%$, which was much higher than other photocatalysts such as $\mathrm{C}-\mathrm{TiO}_{2}$ and $\mathrm{N}-\mathrm{C}-\mathrm{TiO}_{2}$. Chen et al. [322] prepared $\mathrm{TiO}_{2}$ co-doped with $\mathrm{Ce}$ and $\mathrm{N}$ via a sol-gel method and then incorporated diatomaceous earth particles into $\mathrm{Ce}-\mathrm{N}-\mathrm{TiO}_{2}$ to form a composite photocatalyst. $\mathrm{N}$ ion doping reduces the forbidden bandgap of the $\mathrm{TiO}_{2}$ composite catalyst, and the composite $\mathrm{TiO}_{2}$ becomes a photoelectron trap due to the special $4 \mathrm{f}$ energy level of the Ce element. Therefore, under visible light irradiation for $240 \mathrm{~min}$, the degradation rate of oxytetracycline by $\mathrm{Ce}-\mathrm{N}-\mathrm{TiO}_{2} / \mathrm{G}$ is almost $100 \%$, which is much higher than other catalysts. Han et al. [323] used a sol-gel method to prepare $\mathrm{Zr}$, $\mathrm{Ni}$ and $\mathrm{N}$ co-doped $\mathrm{TiO}_{2}$ catalyst. Under visible light irradiation, the conversion of $\mathrm{NO}$ and $\mathrm{SO}_{2}$ gas by the three element co-doped $\mathrm{TiO}_{2}$ photocatalyst is much higher than that of the single or two element $(\mathrm{Zr}, \mathrm{Ni}, \mathrm{N})$ doped $\mathrm{TiO}_{2}$ photocatalyst. Mixed doping can effectively increase the light absorption of the composite in the visible region, which is the main reason for the enhanced photocatalytic activity.

\subsection{Surface Dye Photosensitization}

Surface dye photosensitization refers to the process of using a photosensitizer to broaden the wavelength response range of the photochemical reaction. Photosensitizers are usually some inorganic or organic chromophores. Photosensitizers have strong absorption under visible light and can extend the spectral response range of the photocatalytic system to the visible region. Therefore, the sensitized semiconductor catalyst can be excited with visible light of a much lower energy than ultraviolet light, which can broaden the application of a photocatalyst in the visible light region. Previous work on the photosensitization of semiconductor dyes mainly involved solar cells and photocatalytic hydrogen production, and in recent years the use of dye-sensitized semiconductor catalysts for decomposing organic pollutants has attracted the intense attention of researchers. Surface dye photosensitization has become one of the common methods for modifying semiconductor catalysts. Common photosensitizers include various organic dyes and transition metal complexes such as $\mathrm{Ru}$ and $\mathrm{Pt}$ chloride.

Wan et al. [324] used a modified hydrothermal reflux composite preparation method to prepare porphyrin-sensitized $\mathrm{TiO}_{2} /$ reduced graphene oxide $\left(\mathrm{TiO}_{2} / \mathrm{RGO}\right)$ composite nanorod catalysts. Under visible light irradiation, the decomposition rate of methylene blue by $\mathrm{TiO}_{2} / \mathrm{RGO}$ composite nanorods is very high at $92 \%$, which is 4.3 times the decomposition rate of pure $\mathrm{TiO}_{2}$ nanorods to methylene blue. Zoltan et al. [325] used three asymmetric sensitizers 5-(p-Nitrophenyl)-10,15,20-triphenylporphyrin, $\mathrm{Cu}$ (II)-porphyrin, and $\mathrm{Zn}$ (II)-porphyrin] for the sensitization modification of polycrystalline $\mathrm{TiO}_{2}$ powder. The experimental results showed that the degradation rate of Congo red by the $\mathrm{Zn}(\mathrm{II})$-porphyrin sensitized $\mathrm{TiO}_{2}$ semiconductor catalyst is higher than that of other photocatalysts. Zhao et al. [326] attached the carboxylate porphyrins of $\mathrm{Cu}, \mathrm{Co}$, and $\mathrm{Zn}$ to the surface of $\mathrm{TiO}_{2}$ by a hydrothermal method. In the degradation study of nitrophenol, the three sensitized semiconductor catalysts had a higher catalytic activity than pure $\mathrm{TiO}_{2}$. Among the three sensitized semiconductor catalysts, $\mathrm{Cu}$-porphyrin- $\mathrm{TiO}_{2}$ has the best decomposition ability of nitrophenol. This is because $\mathrm{Cu}$ ions are excellent electron acceptors, and it is easier to attract electrons to reach a stable state, thereby achieving 
the effect of separating electron-hole pairs. Wei et al. [327] used a two-step method of hydrothermal and reflux to prepare a $\mathrm{Cu}$ (II)-tetrakis(4-carboxyphenyl)porphyrin and $\mathrm{RGO}$ co-sensitized $\mathrm{TiO}_{2}$ nanorod photocatalyst. After irradiation for $120 \mathrm{~min}$ under visible light, the decomposition rate of methylene blue by the composite $\mathrm{TiO}_{2}$ photocatalyst was $95 \%$, which was five times that of pure $\mathrm{TiO}_{2}$ to methylene blue. Furthermore, the composite $\mathrm{TiO}_{2}$ photocatalyst still maintained stable catalytic performance after being used six times in photocatalyst experiments.

Chowdhury et al. [328] reported the use of eosin dye to photosensitize $\mathrm{TiO}_{2}$ and successfully reduced the band gap of a $\mathrm{TiO}_{2}$ semiconductor by $1 \mathrm{eV}$. After sensitization, the catalyst showed a strong photo response in the visible region. Eosin dyes can inject excited electrons into the $\mathrm{TiO}_{2}$ conduction band to achieve the same function as photogenerated electrons. Altin et al. [329] photosensitized $\mathrm{Co}-\mathrm{TiO}_{2}$ nano-doped particles with a metal-free complex-free phthalocyanine dye derivative by the sol-gel method. The prepared semiconductor catalyst exhibited an obviously red shift in the absorption wavelength, a shift which improved the application of the catalyst in the visible region. In the study of pollutant degradation, it was found that the photosensitization photocatalyst prepared by using Tween 20 surfactant had the best degradation performance, and the degradation rate of methyl orange (MB) dye $(10 \mathrm{mg} / \mathrm{L})$ by the photosensitization photocatalyst reached $60.3 \%$ under $150 \mathrm{~min}$ of visible light irradiation. Albay et al. [330] employed a deposition method to cure the novel $\mathrm{Cu}$ (II)-phthalocyanine derivative on the surface of $\mathrm{TiO}_{2}$ nanoparticles to achieve a photosensitization modification. The results showed that photosensitization has little effect on the morphology of $\mathrm{TiO}_{2}$, but photosensitized $\mathrm{TiO}_{2}$ enhances the response to visible light. Under visible light, the bactericidal capacity of photosensitized $\mathrm{TiO}_{2}$ and the conversion rate of photosensitized $\mathrm{TiO}_{2}$ to $\mathrm{Cr}^{6+}$ ions are much higher than those of a pure $\mathrm{TiO}_{2}$ photocatalyst.

As a traditional modification method, surface dye photosensitization has been well developed in its development and application. One frequently used method of sensitization is to apply many dyes to the surface of the semiconductor. This method achieves good results in sensitization applications for nanoparticle solar cells, and there are articles about this method in famous journals such as Nature [331,332]. While the photosensitization of surface dyes can improve the photo responsive range and photocatalytic efficiency of photosensitized semiconductor catalysts, the photosensitization of surface dyes also has some drawbacks. First, the presence of surface photosensitizers limits the increase in photocatalytic efficiency of semiconductor photocatalysts. Second, the stability of photosensitizers for long-term use is questioned. Photosensitizers can fall off from the surface of the catalyst and can result in the secondary contamination to water. Furthermore, some photosensitizing dyes, such as ruthenium-based dyes, are expensive and not suitable for a wide range of applications.

In Table 3, we summarize both the advantages and disadvantages of the above modification methods.

Table 3. Advantages and disadvantages of different modification methods for semiconductor.

\begin{tabular}{cll}
\hline Modification Method & \multicolumn{1}{c}{ Advantage } & Disadvantage \\
\hline Particle doping & $\begin{array}{l}\text { - Reduce bandgap } \\
\text { - Reduce particle size }\end{array}$ & - Introduce defects \\
\hline Precious metal depositing & - Enhance electron-hole separation & - Expensive \\
\hline Surface dye photosensitization & - Broaden the light response range & - Expensive \\
\hline Semiconductor compound & - Reducing the complex of electron-hole pairs & - Energy loss \\
\hline
\end{tabular}

\section{Application}

\subsection{Photocatalytic Hydrogen Production}

In recent decades, the use of petroleum and coal resources has been increasing, and the number of unrepairable resources on Earth is getting fewer and fewer. Furthermore, combustion of fossil fuels has 
caused many environmental problems that have significantly influenced the development of science and technology, as well as the daily life of humans.

Hydrogen is considered the most promising clean energy source of the 21st century. Hydrogen is characterized by being odorless, non-toxic, environmentally friendly, and capable of producing a large amount of energy. Hydrogen energy is a secondary energy source and needs to be prepared from other hydrogen-containing substances such as water and fossil fuels. There are a variety of ways of producing hydrogen, and the most common way is to decompose fossil fuels to produce hydrogen. However, this method relies on fossil fuels in the final analysis. The photocatalytic degradation of water to produce hydrogen to achieve the conversion of solar energy to hydrogen energy is an effective method to solve energy and environmental problems. The photocatalytic decomposition of water to generate hydrogen can convert solar energy into hydrogen energy, which is an effective method to solve energy and environmental problems.

Since the first photocatalytic decomposition of water to produce hydrogen in 1972, researchers have used powdered semiconductor materials to achieve the photocatalytic decomposition of water to produce hydrogen $[7,215$ ? -220]. Photocatalytic hydrogen production not only achieves the use of solar energy but also reduces environmental problems caused by energy use. Therefore, photocatalytic technology is considered to be the most ideal and cleanest way to produce and utilize energy $[333,334]$.

Monoatomic catalysts can reduce costs by reducing the amount of precious metals used, but the challenge is how to maintain catalyst stability. Zhang et al. synthesized a bimetallic MXene nanosheet $\mathrm{Mo}_{2} \mathrm{TiC}_{2} \mathrm{~T}_{\mathrm{x}}$ [335]. A large amount of Mo vacancies formed in the outer layer of the $\mathrm{Mo}_{2} \mathrm{TiC}_{2} \mathrm{~T}_{\mathrm{x}}$, and after the Pt atoms were fixed in these vacancies, the hydrogen generation effectiveness of the $\mathrm{Mo}_{2} \mathrm{TiC}_{2} \mathrm{~T}_{\mathrm{x}}$ was greatly improved, as shown in Figure $8 \mathrm{~B}$. The hydrogen evolution catalytic activity of the catalyst reached a current density of $100 \mathrm{~mA} / \mathrm{cm}^{2}$, requiring only an overpotential of $77 \mathrm{mV}$. $\mathrm{Mo}_{2} \mathrm{TiC}_{2} \mathrm{~T}_{\mathrm{x}}$ has a 40-fold increase in mass activity compared to the commercially available platinum-carbon catalyst. Studies have shown that the superior catalytic performance and stability of $\mathrm{Mo}_{2} \mathrm{TiC}_{2} \mathrm{~T}_{\mathrm{x}}$ arises from the covalent effect of $\mathrm{Pt}$ and MXene. As shown in Figure $8 \mathrm{~A}, \mathrm{Mo}_{2} \mathrm{TiC}_{2} \mathrm{~T}_{\mathrm{x}}-\mathrm{PtSA}$ showed the best performance in all samples.

A

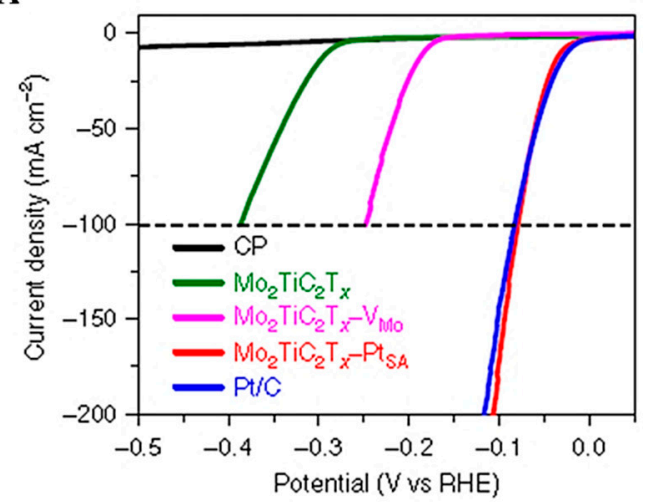

B

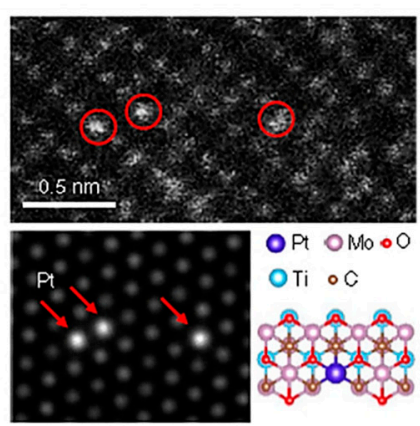

Figure 8. (A) Electrocatalytic performance for $\mathrm{Mo}_{2} \mathrm{TiC}_{2} \mathrm{~T}_{x}$-PtSA and reference HeR catalysts. (B) Magnified HAADF-STEM image of $\mathrm{Mo}_{2} \mathrm{TiC}_{2} \mathrm{~T}_{\mathrm{x}}$-PtSA and its corresponding simulated image, as well as an illustration of the structure of $\mathrm{Mo}_{2} \mathrm{TiC}_{2} \mathrm{~T}_{\mathrm{x}}-\mathrm{PtSA}$, showing the isolated Pt atoms (circles in c) [335].

Bi et al. [336] synthesized g- $\mathrm{C}_{3} \mathrm{~N}_{4}$ combined with $\mathrm{PtNi}$. As shown in Figure 9A, the $\mathrm{PtNi} \times \mathrm{C}_{\mathrm{x}} / \mathrm{g}-\mathrm{C}_{3} \mathrm{~N}_{4}$ composites with different mass ratios have higher photocatalytic activities than pure $g-C_{3} N_{4}$. In the composite material, $2.5 \% \mathrm{PtNi}_{\mathrm{x}} / \mathrm{g}-\mathrm{C}_{3} \mathrm{~N}_{4}\left(8456 \mu \mathrm{mol} \cdot \mathrm{h}^{-1} \mathrm{~g}^{-1}\right)$ shows the highest rate of photocatalytic hydrogen generation, which is about 16 times of the rate of pure ${ }^{-} \mathrm{C}_{3} \mathrm{~N}_{4}\left(515 \mu \mathrm{mol} \cdot \mathrm{h}^{-1} \mathrm{~g}^{-1}\right)$ photocatalytic hydrogen. From Figure $9 \mathrm{~B}$, the emission peak of pure g- $\mathrm{C}_{3} \mathrm{~N}_{4}$ at about $470 \mathrm{~nm}$ can be observed, which is recombined in response to band gap electron-hole pairs. In addition, $2.5 \% \mathrm{PtNix} / \mathrm{g}-\mathrm{C}_{3} \mathrm{~N}_{4}$ shows a weaker emission peak intensity relative to pure g-C $3 \mathrm{~N} 4$, which means that the photoexcitation electron 
and hole recombination rate in $2.5 \% \mathrm{PtNi}_{\mathrm{x}} / \mathrm{g}-\mathrm{C}_{3} \mathrm{~N}_{4}$ is lower $[337,338]$. In other words, after loading $\mathrm{PtNi}_{\mathrm{x}}$ onto g- $\mathrm{C}_{3} \mathrm{~N}_{4}$, it can effectively suppress the recombination of the photogenerated charge, thereby improving photocatalytic performance.
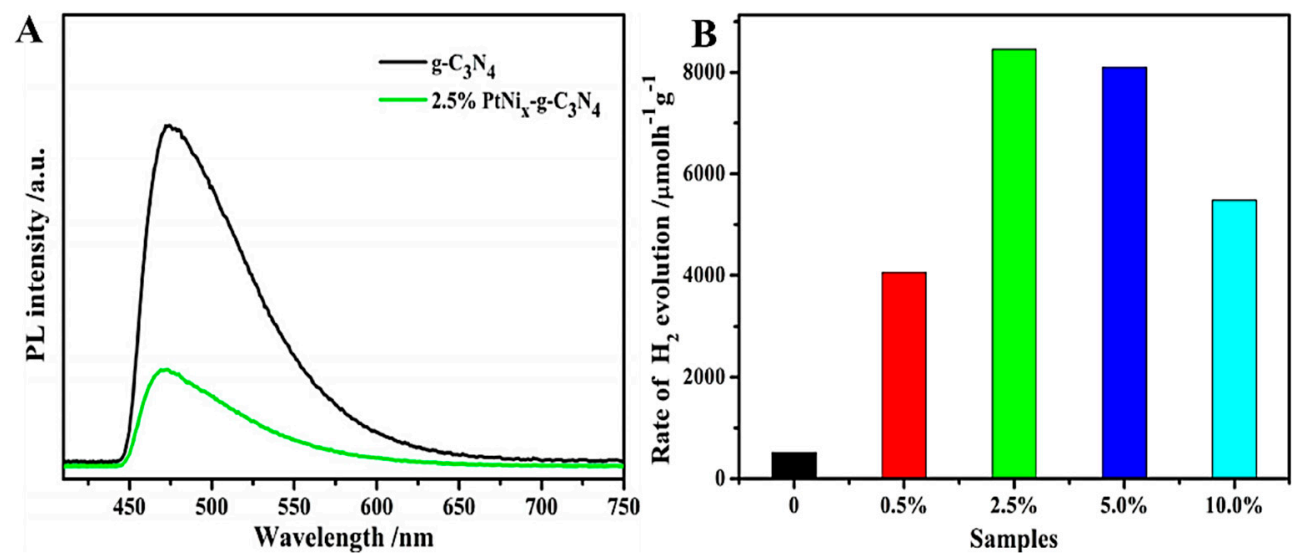

Figure 9. (A) Comparison of the photocatalytic $\mathrm{H}_{2}$ production activity of $\mathrm{g}-\mathrm{C}_{3} \mathrm{~N}_{4}, 0.5 \% \mathrm{PtNi} / \mathrm{g}-\mathrm{C}_{3} \mathrm{~N}_{4}$, $2.5 \% \mathrm{PtNi} \mathrm{x}_{\mathrm{x}} / \mathrm{g}-\mathrm{C}_{3} \mathrm{~N}_{4}, 5.0 \% \mathrm{PtNi} / \mathrm{g}-\mathrm{C}_{3} \mathrm{~N}_{4}$, and $10.0 \% \mathrm{PtNi} \times \mathrm{g}_{\mathrm{x}}-\mathrm{C}_{3} \mathrm{~N}_{4}$ samples using triethanolamine as the scavenger under a $500 \mathrm{~W}$ Xe lamp irradiation. (B) Photoluminescence (PL) spectra of $2.5 \% \mathrm{PtNi}_{\mathrm{x}}-\mathrm{g}-\mathrm{C}_{3} \mathrm{~N}_{4}$ and $g-\mathrm{C}_{3} \mathrm{~N}_{4}$ [336].

Jiang et al. [339] prepared a $\mathrm{Bi}_{3} \mathrm{TiNbO}_{9}$ and $\mathrm{Cr} / \mathrm{Nb}$ co-doped $\mathrm{Bi}_{3} \mathrm{Ti}_{1-2 x} \mathrm{Cr}_{\mathrm{x}} \mathrm{Nb}_{1+\mathrm{x}} \mathrm{O}_{9}(\mathrm{x}=0.1,0.2$, 0.3) photocatalyst by the solid state reaction method. The doping of $\mathrm{Cr} / \mathrm{Nb}$ can reduce the band gap of $\mathrm{Bi}_{3} \mathrm{TiNbO}_{9}$ by $1 \mathrm{eV}$. Figure $10 \mathrm{~A}$ shows the hydrogen evolution experiment of all samples under full range illumination. Continuous hydrogen generation was detected through the experiment, and $\mathrm{Cr} / \mathrm{Nb}$ co-doped $\mathrm{Bi}_{3} \mathrm{TiNbO}_{9}$ showed a higher hydrogen generation rate than pure $\mathrm{Bi}_{3} \mathrm{TiNbO}_{9}$. In the doped sample, $\mathrm{Bi}_{3} \mathrm{Ti}_{0.8} \mathrm{Cr}_{0.1} \mathrm{Nb}_{1.1} \mathrm{O}_{9}(\mathrm{x}=0.1)$ showed the highest hydrogen generation rate, which was about twice that of pure $\mathrm{Bi}_{3} \mathrm{TiNbO}_{9}$. However, as the amount of $\mathrm{Cr} / \mathrm{Nb}$ doping further increased, the hydrogen generation rate of the photocatalyst after doping decreased by $40 \%$. The average photocatalytic hydrogen production rate under different irradiation conditions is given in Figure 10B.
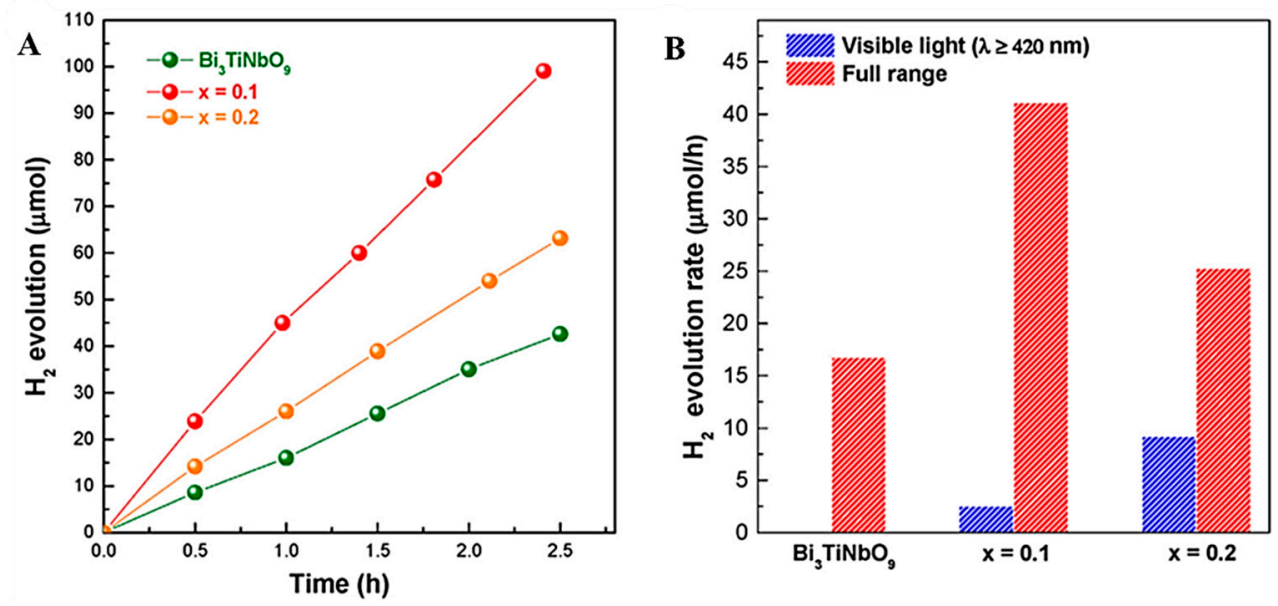

Figure 10. (A) Photocatalytic hydrogen production of all samples under full range illumination $(\lambda \geq 250 \mathrm{~nm})$ in sodium sulfite aqueous solution $(0.05 \mathrm{M})$. (B) Average photocatalytic hydrogen production rate under full range $(\lambda \geq 250 \mathrm{~nm})$ and visible light illumination $(\lambda \geq 420 \mathrm{~nm})$ [339].

\subsection{Wastewater Treatment}

Since the beginning of the 21st century, the problem of water pollution has become increasingly severe, and it has become a major issue affecting human health that restricts the harmonious 
development of society. One of the main symptoms of water pollution is industrial wastewater. Industrial wastewater often includes oil substances, reaction aids, paper stocks, acids and alkaline substances, fiber impurities, dyes, and inorganic salt substances. Industrial wastewater is generally difficult to degrade. Today, methods for decomposing industrial wastewater are mainly biological methods, chemical methods, and physical methods. However, the above three methods do not clean the waste water completely-they all have some drawbacks.

In 1977, Frank et al. applied photocatalytic technology to the degradation of pollutants in water systems [340], laying the foundation for the use of photocatalytic oxidation technology in pollutant treatment. In the photocatalytic degradation of water pollution, active substances such as $\mathrm{H}^{+}, \mathrm{H}_{2} \mathrm{O}_{2}$, and $\cdot \mathrm{OH}$ generated by photocatalysts have a strong oxidizing activity and can deeply oxidize most of the organic pollutants in water into harmless small molecules. Therefore, a photocatalyt can be used for the purification of wastewater containing organic pollutants. Photocatalysis technology as a new high-efficiency and energy-saving modern sewage treatment technology has many advantages in wastewater treatment [341-352]. Compared to the traditional wastewater treatment method, photocatalytic technology can fundamentally remove pollutants, and, regardless of the pollutants' liquid or gaseous state, photocatalytic technology can have a good degradation effect.

In 2001, Houas et al. [351] used methylene blue to simulate environmental wastewater. Their experimental results showed that titanium dioxide based photocatalysts can successfully degrade methylene blue. Lachheb et al. [352] used UV light to irradiate a titanium dioxide photocatalyst to achieve the degradation of five different dyes (alizarin S, crocein orange G, methyl red, Congo red, and methylene blue). Experimental results showed that the five dyes not only decolorized successfully but also completely decomposed. Liu et al. [174] prepared flexible composite $\mathrm{Fe}_{2} \mathrm{O}_{3} / \mathrm{TiO}_{2}$ nanofibers by combining a traditional electrospinning method and calcination process, which they successfully applied to photocatalytic wastewater treatment and photocurrent detection. In the photocatalytic degradation of rhodamine $\mathrm{B}$ experiment, $\mathrm{Fe}_{2} \mathrm{O}_{3} / \mathrm{TiO}_{2}$ nanofibers have higher photocatalytic activity than pure $\mathrm{TiO}_{2}$ under UV and visible light. The most important thing is that the $\mathrm{Fe}_{2} \mathrm{O}_{3} / \mathrm{TiO}_{2}$ photocatalyst can be recovered by magnetic materials, thereby avoiding secondary pollution to the environment after photocatalytic treatment. Zhang et al. [167] synthesized flexible rime-like branched $\mathrm{TiO}_{2} / \mathrm{PVDF}$ composites via the electrospinning method and the hydrothermal method. In the photolysis rhodamine $\mathrm{B}$ experiments, the prepared flexible $\mathrm{TiO}_{2} / \mathrm{PVDF}$ composites showed a higher photocatalytic efficiency than pure PVDF. In particular, the $\mathrm{TiO}_{2} / \mathrm{PVDF}(\mathrm{H} 10)$ composite treated for $10 \mathrm{~h}$ in the hydrothermal reaction showed the highest photocatalytic activity (as show in Figure 11A). As shown in Figure $11 \mathrm{~B}$, the $\mathrm{TiO}_{2} / \mathrm{PVDF}(\mathrm{H} 10)$ composite still maintains its high photocatalytic efficiency after five photocatalytic experiments.
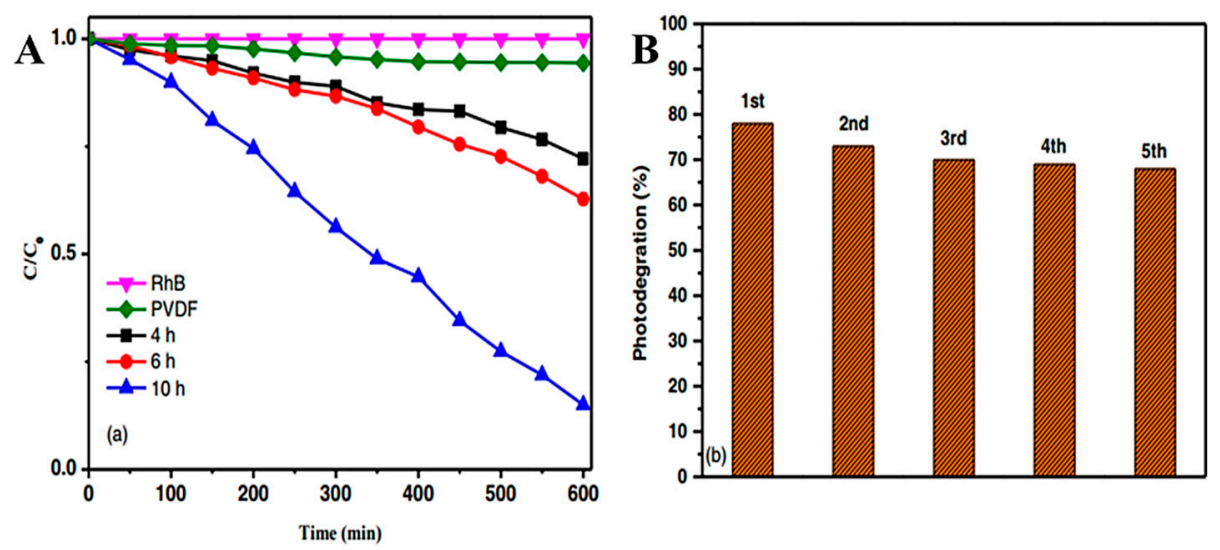

Figure 11. (A) Photodegradation profiles of rhodamine B over the samples: Rhodamine B without photocatalyst, PVDF and $\mathrm{TiO}_{2} / \mathrm{PVDF}$ composites hydrothermal treated for $4 \mathrm{~h}, 6 \mathrm{~h}$, and $10 \mathrm{~h}$. (B) The photocatalyst treated for $10 \mathrm{~h}$ was used for rhodamine $\mathrm{B}$ degradation, and the number of cycles was five times [167]. 
Regmi et al. [353] synthesized Ni-doped $\mathrm{BiVO}_{4}$ photocatalysts using the microwave hydrothermal method. In the photocatalytic degradation experiments, the Ni-doped $\mathrm{BiVO}_{4}$ photocatalyst showed better photocatalytic performance than pure $\mathrm{BiVO}_{4}$. As shown in Figure 12, pure $\mathrm{BiVO}_{4}$ has a strong absorption in the UV to $510 \mathrm{~nm}$ range, while the absorption edge of Ni-doped samples is significantly red-shifted as the Ni dopant concentration increases. In Figure 13, Regmi and coworkers evaluated the photocatalytic disinfection activity of $\mathrm{BiVO}_{4}$ and Ni-doped $\mathrm{BiVO}_{4}$ by inactivating Escherichia coli in an aqueous buffer solution under different light sources. The results show that pure $\mathrm{BiVO}_{4}$ and $1 \mathrm{wt} \% \mathrm{Ni}$-doped $\mathrm{BiVO}_{4}$ require only $1 \mathrm{~h}$ to inactivate E. coli to $100 \%$ under full spectrum sunlight illumination. However, after visible light irradiation for $5 \mathrm{~h}$, the inactivation rate of pure $\mathrm{BiVO}_{4}$ against E. coli reaches $72 \%$, while the $3 \mathrm{wt} \%$ and $1 \mathrm{wt} \% \mathrm{Ni}$-doped $\mathrm{BiVO}_{4}$ against $E$. coli inactivation rate of is $89 \%$ and $92 \%$, respectively. Obviously, $1 \mathrm{wt} \% \mathrm{Ni}$-doped $\mathrm{BiVO}_{4}$ shows higher efficiency, and as the doping amount of $\mathrm{Ni}$ increases the inactivation rate of $E$. coli gradually decreases.

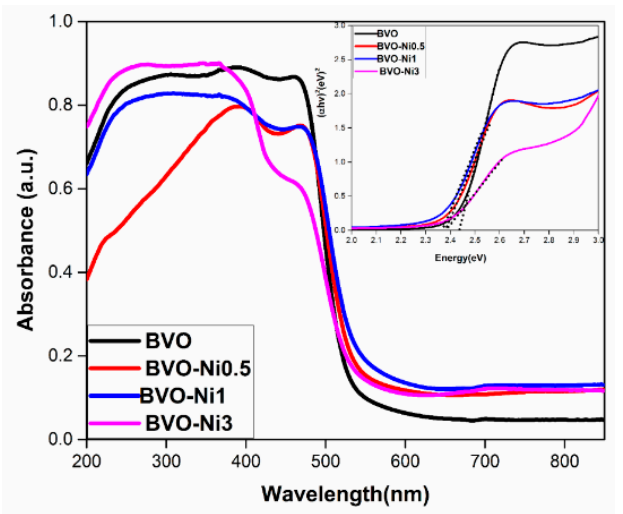

Figure 12. UV-Vis diffuse reflectance spectra of $\mathrm{BiVO}_{4}$ samples with different $\mathrm{wt} \%$ of $\mathrm{Ni}$ ions. Inset is the Kubelka-Munk plot with the corresponding band gap energies [353].
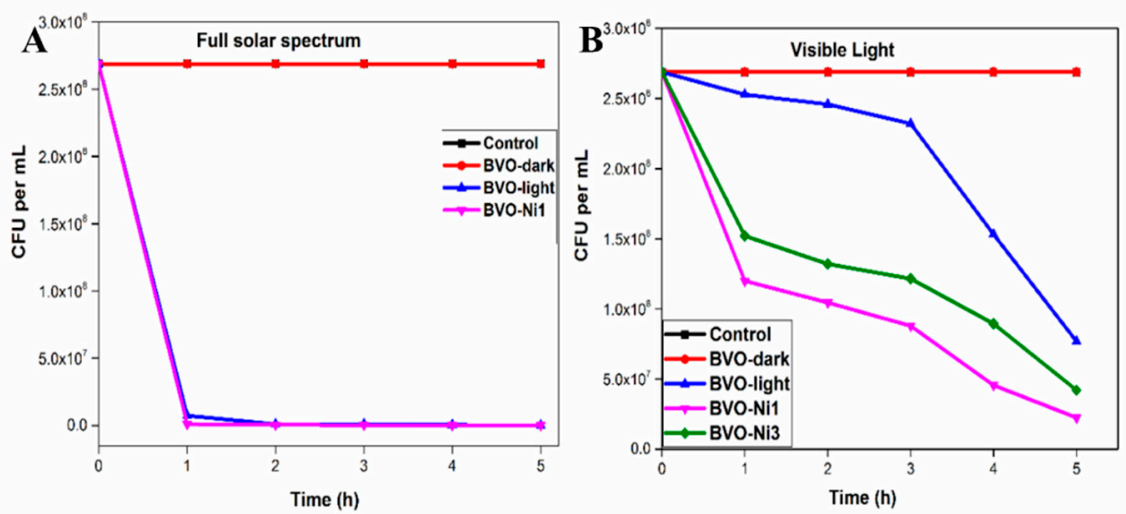

Figure 13. Inactivation of E. coli on: (A) Irradiation to full solar spectrum light; (B) visible light [353].

Cai et al. [354,355] developed a simple two-step method to prepare three-dimensional ordered macroporous (3DOM) gold-loaded $\mathrm{TiO}_{2}$ photonic crystal photocatalysts. Based on this method, following the procedures shown in Figure $14 \mathrm{~A}, \mathrm{i}-\mathrm{TiO}_{2}-\mathrm{o}$ and $\mathrm{i}-\mathrm{Au}-\mathrm{TiO}_{2}-\mathrm{o}$ photocatalysts were further generated. Both $\mathrm{i}-\mathrm{TiO}_{2}-\mathrm{o}$ and $\mathrm{i}-\mathrm{Au}-\mathrm{TiO}_{2}-\mathrm{o}$ films prepared by this method exhibit a highly ordered interconnected porous structure, which is advantageous for the adsorption of target contaminants and utilization of solar energy. In the decomposition experiments of benzoic acid (BA), both $\mathrm{i}-\mathrm{TiO}_{2}-\mathrm{O}$ and $\mathrm{i}-\mathrm{Au}-\mathrm{TiO}_{2}-\mathrm{o}$ showed higher decomposition rates than anatase $\mathrm{TiO}_{2}$. As shown in Figure 14B, under ultraviolet irradiation, the decomposition rate of $\mathrm{BA}$ by $\mathrm{i}-\mathrm{Au}-\mathrm{TiO}_{2}-\mathrm{O}$ is five or more times the decomposition rate of $\mathrm{BA}$ by anatase-type $\mathrm{TiO}_{2}$. 


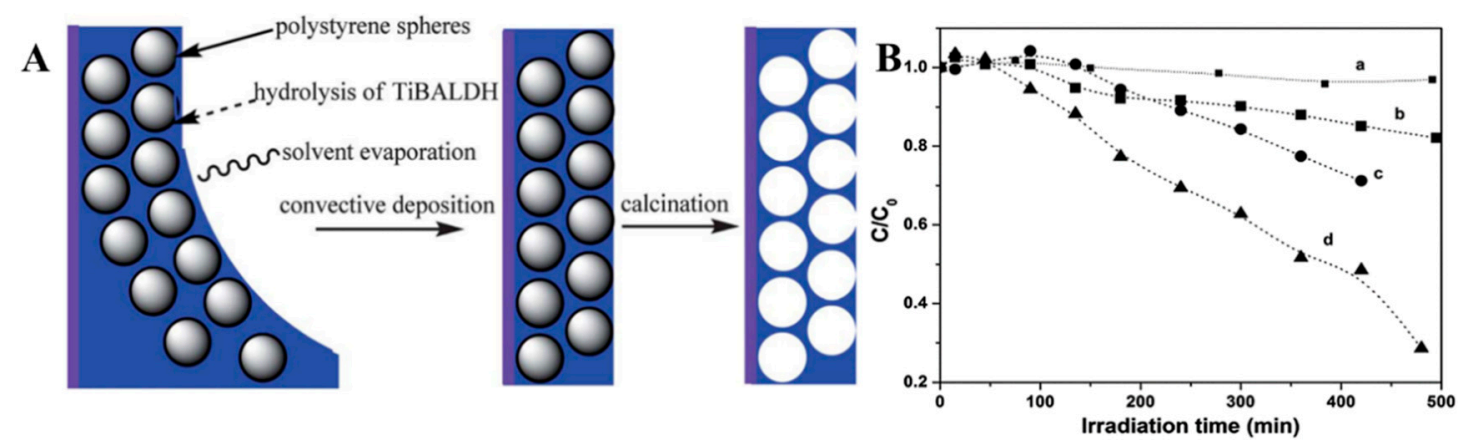

Figure 14. (A) Schematic illustration of procedures for the fabrication of $3 \mathrm{DOM} \mathrm{TiO}_{2}$ films loaded with gold nanoparticles. (B) Photocatalytic degradation of benzoic acid (BA) over (a) i-Au- $\mathrm{TiO}_{2}$-o without UV irradiation, (b) nanocrystalline $\mathrm{TiO}_{2}$, (c) $\mathrm{i}-\mathrm{TiO}_{2}-\mathrm{o}$, and (d) $\mathrm{i}-\mathrm{Au}-\mathrm{TiO}_{2}$-o under UV irradiation [354].

\subsection{Photocatalytic Disinfection}

As well as non-biological contaminants such as organic pesticides, antibiotics, and heavy metals in water, the harm caused by biological pollution such as medical sewage and domestic wastewater cannot be underestimated. Most pathogenic microorganisms can cause harm to human health by ingestion, respiration, or skin contact. According to the report, millions of people are dying or dead as a result of infection with pathogens annually [356].

Traditional sterilization methods for disinfection such as chlorination, ozonation, and ultraviolet light all have disadvantages. Chlorine can kill most bacteria and viruses, but the chlorine byproducts generated during the reaction can also endanger human health. Ozone oxidation technology is highly demanding on equipment and complicated to operate. Low-pressure ultraviolet disinfection can only inactivate bacteria on the surface of sewage; at the same time, the equipment is poor in reliability and expensive. For the first time, Matsunaga et al. [357] demonstrated that photocatalytic technology can eliminate pathogens including Lactobacillus, yeast, and Escherichia coli. Thereafter, photocatalytic antibacterial materials have been gradually known and developed.

In the past few decades, the photocatalytic technology of nanomaterials has been rapidly developed in solar photocatalytic sterilization and other aspects [358-367]. The reaction mechanism of photocatalytic sterilization is to destroy the cell wall and oxidize coenzyme A enzymes and genetic material. Under ultraviolet light irradiation, $\cdot \mathrm{OH}$ radicals and $\mathrm{O}^{2-}$ radicals generated on the surface of the photocatalyst easily adhere to the cell wall surface of the bacteria. These free radicals can cause the leakage of $\mathrm{K}^{+}$ions in the cell fluid, the oxidation of coenzyme $\mathrm{A}$ in the cell, or the destruction of the DNA double helix structure. There is also a class of photocatalysts that do not produce active $\cdot \mathrm{OH}$ during photocatalytic and antimicrobial processes, and this type of photocatalyst sterilizes pathogens using photogenerated holes. As a new sterilization method, photocatalytic sterilization has the advantages of high safety, strong stability, and wide antibacterial properties, and it demonstrates broad application prospects.

Obuchi et al. [368] obtained $\mathrm{TiO}_{2} / \mathrm{SiO}_{2}$ and $\mathrm{Ag}-\mathrm{TiO}_{2} / \mathrm{SiO}_{2}$ photocatalysts by hydrolysis and the calcination method. Figure 15 shows the survival rate of spore-forming Bacillus subtilis to treatment time under UV irradiation and dark conditions and the relationship between the doping amount of $\mathrm{Ag}$ and the disinfection rate constant, respectively. Figure 15A shows that the viability of sporulated Bacillus subtilis reduced only when using $\mathrm{Ag}-\mathrm{TiO} / \mathrm{SiO}$ under ultraviolet irradiation. As shown in Figure $15 \mathrm{~B}$, the optimum range of the $\mathrm{Ag}$ doping amount is $0.5-1.0 \mathrm{wt} \%$. 

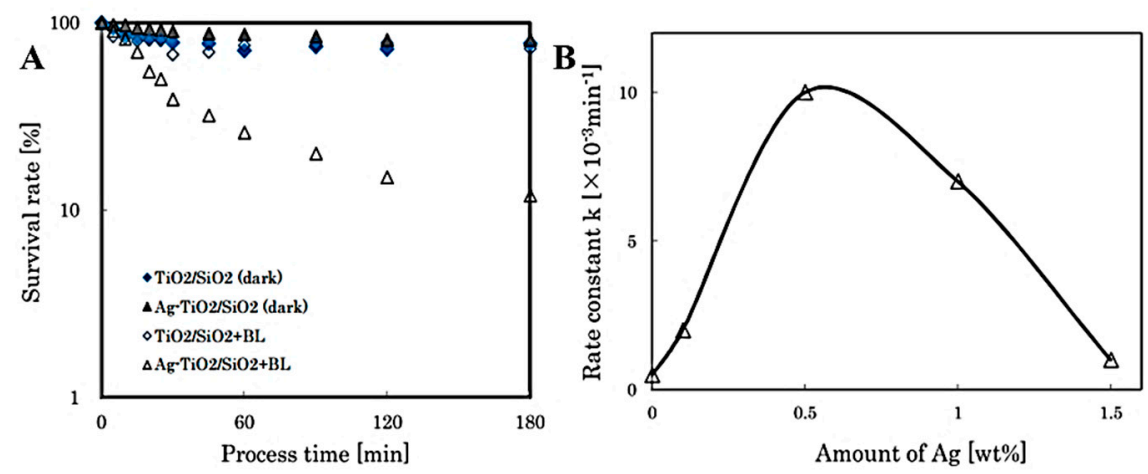

Figure 15. (A) Survival rate of sporulating Bacillus subtilis against process time using $\mathrm{TiO}_{2} / \mathrm{SiO}_{2}$ and Ag-doped $\mathrm{TiO}_{2} / \mathrm{SiO}_{2}$ (BL; under ultraviolet irradiation, dark; without UV irradiation). (B) Relationship between Ag amount and rate constant [368].

\subsection{Air Purification}

Air quality is closely related to the health of human beings. In recent years, researchers have agreed that air pollution is closely related to respiratory infections, lung diseases, cardiovascular disease, and coronary heart disease [68-73,369-372]. To date, the main sources of air pollution are industrial waste gas and automobile exhaust gas. Sulfur compounds such as sulfur dioxide, nitrogen oxides, halogen-containing compounds, and malodorous gases contained in industrial exhaust gases, as well as carbon monoxide, nitrogen oxides, and sulfur oxygen compounds in automotive exhaust gases, have a significant impact on people's health. Another major pollutant is volatile organic compounds (VOCs). VOCs are organic pollutants widely found in indoor and outdoor air. VOCs are precursors of PM 2.5 and also are the most important air pollutants after PM 2.5 [373,374].

With the development of photocatalysis, the use of photocatalysts to decompose air pollutants has received increasing attention from researchers [375-382]. Photocatalytic material could adsorb or decompose toxic gases in the atmosphere, reducing the adverse effects of toxic gases on the environment. Semiconductor photocatalysis is mild, and the reaction process is relatively simple. In theory, photocatalysis can degrade almost all air pollutants. Therefore, compared with conventional methods such as filtration, adsorption, plasma, and ozone oxidation, photocatalytic technology can completely degrade the pollutants in the air under sunshine, thereby rapidly purifying the air.

Photocatalysis is a technology with wide applications and great development potential. As shown in Figure 16, in addition to the above four applications, photocatalytic technology is also widely used in agriculture, construction, automobiles, roads, and household appliances.

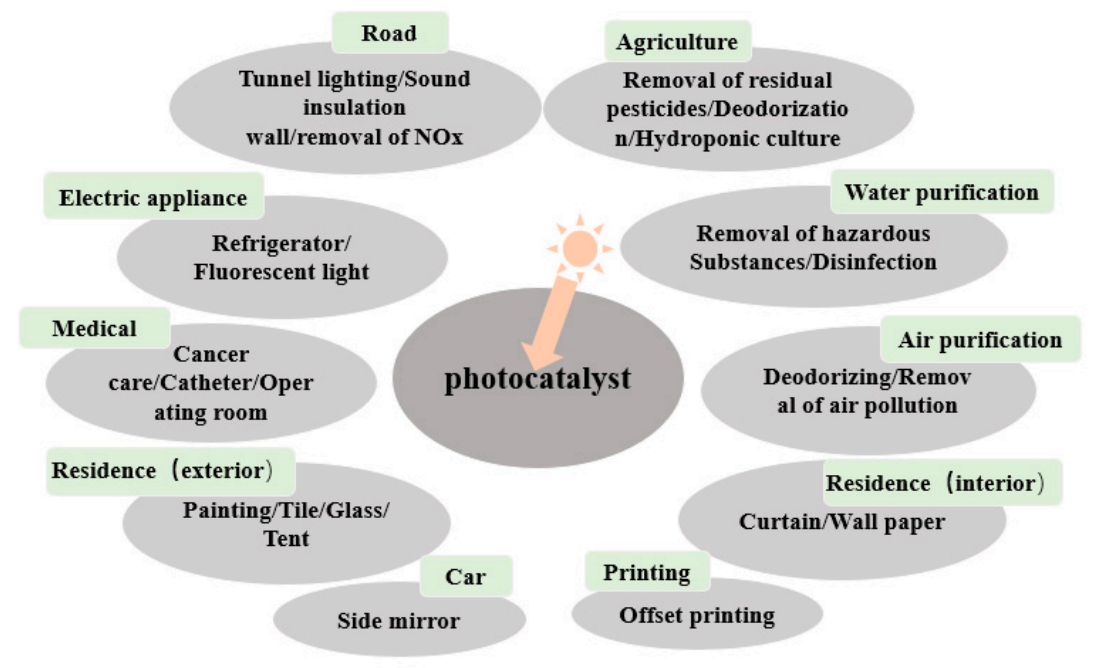

Figure 16. Applications of semiconductor photocatalysis. 


\section{Summary and Outlook}

In summary, the study on photocatalytic technology has developed for decades and has achieved substantial breakthrough in theory and a series of practical application results. Due to the simple photocatalysis oxidation equipment, easy control of operating conditions, strong oxidizing ability, no secondary pollution, and its broad applications in photocatalytic hydrogen production, the degradation of sewage, sterilization, and the purification of air, it has become a highly promising technology. In this review, the mechanism and application of photocatalyst technology, classification, modification, etc. have been summarized in detail. To date, the development of photocatalytic technology is far from meeting the demand for industrialization for many reasons. The photocatalyst prepared at this stage has several disadvantages such as the low utilization of sunlight, low quantum efficiency, low recyclability, and low photocatalyst efficiency. Therefore, researchers still need to devote more efforts to find a highly efficient and stable visible light photocatalyst in order to improve photocatalytic efficiency and promote the application of photocatalytic technology.

Acknowledgments: This work was supported by the National Natural Science Foundation of China $(51,673,103)$ and the National Natural Science Foundation of China $(51,703,102)$. Z.C. is grateful for the support from the joint French-Singaporean MERLION program (Grant No. R279,000,334,133).

Funding: This research was funded by the National Natural Science Foundation of China $(51,703,102)$.

Conflicts of Interest: The authors declare no conflict of interest.

\section{Abbreviations}

Full Name

Valence band

Conduction band

Direct-current power supply

Physical vapor deposition

Chemical vapor deposition

Molecular beam epitaxy

RF magnetron sputtering

Ultraviolet irradiation

Methyl orange

Rhodamine B

Escherichia coli

Benzoic acid

Volatile organic compounds

\author{
Abbreviation \\ $\mathrm{VB}$ \\ CB \\ DC power supply \\ PVD \\ CVD \\ MBE \\ RF-MS \\ UV irradiation \\ $\mathrm{MB}$ \\ RhB \\ E. coli \\ BA \\ VOCs
}

\section{References}

1. Brunekreef, B.; Holgate, S.T. Air pollution and health. Lancet 2002, 360, 1233-1242. [CrossRef]

2. Fujishima, A.; Honda, K. Electrochemical photolysis of water at a semiconductor electrode. Nature 1972, 238, 37-38. [CrossRef] [PubMed]

3. Frank, S.N.; Bard, A.J. Semiconductor electrodes. II. Electrochemistry at n-type titanium dioxide electrodes in acetonitrile solutions. J. Am. Chem. Soc. 1975, 97, 7427-7433. [CrossRef]

4. Horie, Y.; David, D.A.; Taya, M.; Tone, S. Effects of light intensity and titanium dioxide concentration on photocatalytic sterilization rates of microbial cells. Ind. Eng. Chem. Res. 1996, 34, 3920-3926. [CrossRef]

5. Jin, C.; Liu, X.; Tan, L.; Cui, Z.; Yang, X.; Zheng, Y.; Yeung, K.; Chu, P.K.; Wu, S. Ag/AgBr-loaded mesoporous silica for rapid sterilization and promotion of wound healing. Biomater. Sci. 2018, 6, 1735-1744. [CrossRef] [PubMed]

6. $\quad$ Rong, W.; Zhang, W.; Zhu, W.; Yan, L.; Li, S.; Kai, C.; Na, H.; Suo, Y.; Wang, J. Enhanced visible-light-driven photocatalytic sterilization of tungsten trioxide by surface-engineering oxygen vacancy and carbon matrix. Chem. Eng. J. 2018, 348, 292-300. 
7. Li, Q.; Guo, B.; Yu, J.; Ran, J.; Zhang, B.; Yan, H.; Gong, J.R. Highly efficient visible-light-driven photocatalytic hydrogen production of CdS-cluster-decorated graphene nanosheets. J. Am. Chem. Soc. 2011, 133, 10878-10884. [CrossRef] [PubMed]

8. Chu, J.; Han, X.; Yu, Z.; Du, Y.; Song, B.; Xu, P. Highly efficient visible-light-driven photocatalytic hydrogen production on CdS/Cu $\mathrm{S}_{4} / g-\mathrm{C}_{3} \mathrm{~N}_{4}$ ternary heterostructures. ACS Appl. Mater. Interfaces 2018, 10, 20404-20411. [CrossRef]

9. Wang, R.; Shuang, N.; Gang, L.; Xu, X. Hollow $\mathrm{CaTiO}_{3}$ cubes modified by La/Cr co-doping for efficient photocatalytic hydrogen production. Appl. Catal. B Environ. 2018, 225, 139-147. [CrossRef]

10. Wei, R.B.; Huang, Z.L.; Gu, G.H.; Zhu, W.; Zeng, L.; Chen, Y.; Liu, Z.Q. Dual-cocatalysts decorated rimous cds spheres advancing highly-efficient visible-light photocatalytic hydrogen production. Appl. Catal. B Environ. 2018, 231, 101-107. [CrossRef]

11. Zhang, H.; Lin, J.; Li, Z.; Li, T.; Jia, X.; Wu, X.L.; Hu, S.; Lin, H.; Chen, J.; Zhu, J. Organic dye doped graphitic carbon nitride with a tailored electronic structure for enhanced photocatalytic hydrogen production. Catal. Sci. Technol. 2019, 9, 502-508. [CrossRef]

12. Liu, Q.; Zhou, Y.; Kou, J.; Chen, X.; Tian, Z.; Gao, J.; Yan, S.; Zou, Z. High-yield synthesis of ultralong and ultrathin $\mathrm{Zn}_{2} \mathrm{GeO}_{4}$ nanoribbons toward improved photocatalytic reduction of $\mathrm{CO}_{2}$ into renewable hydrocarbon fuel. J. Am. Chem. Soc. 2010, 132, 14385-14387. [CrossRef] [PubMed]

13. Chen, L.; Qin, Y.; Chen, G.; Li, M.; Cai, L.; Qiu, Y.; Fan, H.; Robert, M.; Lau, T.C. A molecular noble metal-free system for efficient visible light-driven reduction of $\mathrm{CO}_{2}$ to CO. Dalton Trans. 2019. [CrossRef]

14. Tan, W.; Cao, B.; Xiao, W.; Zhang, M.; Wang, S.; Xie, S.; Xie, D.; Cheng, F.; Guo, Q.; Liu, P. Electrochemical reduction of $\mathrm{CO}_{2}$ on hollow cubic $\mathrm{Cu}_{2} \mathrm{O} @ \mathrm{Au}$ nanocomposites. Nanoscale Res. Lett. 2019, 14, 63-69. [CrossRef] [PubMed]

15. Vidyasagar, D.; Manwar, N.; Gupta, A.; Ghugal, S.G.; Umare, S.S.; Boukherroub, R. Phenyl-grafted carbon nitride semiconductor for photocatalytic $\mathrm{CO}_{2}$-reduction and rapid degradation of organic dyes. Catal. Sci. Technol. 2019, 9, 822-832. [CrossRef]

16. Hofstadler, K.; Bauer, R.; Novalic, S.; Heisler, G. New reactor design for photocatalytic wastewater treatment with $\mathrm{TiO}_{2}$ immobilized on fused-silica glass fibers: Photomineralization of 4-chlorophenol. Environ. Sci. Technol. 1994, 28, 670-674. [CrossRef] [PubMed]

17. Li, F.B.; Li, X.Z. Photocatalytic properties of gold/gold ion-modified titanium dioxide for wastewater treatment. Appl. Catal. A Gen. 2002, 228, 15-27. [CrossRef]

18. Choi, H.; Stathatos, E.; Dionysiou, D.D. Photocatalytic $\mathrm{TiO}_{2}$ films and membranes for the development of efficient wastewater treatment and reuse systems. Desalination 2007, 202, 199-206. [CrossRef]

19. Vaiano, V.; Iervolino, G. Facile method to immobilize $\mathrm{ZnO}$ particles on glass spheres for the photocatalytic treatment of tannery wastewater. J. Colloid Interface Sci. 2018, 518, 192-199. [CrossRef]

20. Betancourt-Buitrago, L.A.; Ossa-Echeverry, O.E.; Rodriguez-Vallejo, J.C.; Barraza, J.M.; Marriaga, N.; Machuca-Martínez, F. Anoxic photocatalytic treatment of synthetic mining wastewater using $\mathrm{TiO}_{2}$ and scavengers for complexed cyanide recovery. Photochem. Photobiol. Sci. 2019, 18, 853-862. [CrossRef]

21. Fu, X.; Zeltner, W.A.; Anderson, M.A. Applications in photocatalytic purification of air. Stud. Surf. Sci. Catal. 1997, 103, 445-461.

22. Besov, A.S.; Vorontsov, A.V.; Parmon, V.N. Fast adsorptive and photocatalytic purification of air from acetone and dimethyl methylphosphonate by $\mathrm{TiO}_{2}$ aerosol. Appl. Catal. B Environ. 2009, 89, 602-612. [CrossRef]

23. Kako, T.; Ichihara, F.; Liu, G.; Meng, X.; Ye, J. Study on the enhancement of photocatalytic environment purification through ubiquitous-red-clay loading. SN Appl. Sci. 2019, 1, 138-145. [CrossRef]

24. Boyjoo, Y.; Sun, H.; Liu, J.; Pareek, V.K.; Wang, S. A review on photocatalysis for air treatment: From catalyst development to reactor design. Chem. Eng. J. 2017, 310, 537-559. [CrossRef]

25. Wang, W.; Tadé, M.O.; Shao, Z. Nitrogen-doped simple and complex oxides for photocatalysis: A review. Prog. Mater. Sci. 2018, 92, 33-63. [CrossRef]

26. Li, X.; Yu, J.; Wageh, S.; Al-Ghamdi, A.A.; Xie, J. Graphene in photocatalysis: A review. Small 2016, 12, 6640-6696. [CrossRef] [PubMed]

27. Zhou, P.; Yu, J.; Jaroniec, A. All-solid-state Z-scheme photocatalytic systems. Adv. Mater. 2014, 26, 4920-4935. [CrossRef]

28. Wang, W.; Li, G.; Xia, D.; An, T.; Zhao, H.; Wong, P.K. Photocatalytic nanomaterials for solar-driven bacterial inactivation: Recent progress and challenges. Environ. Sci. Nano 2017, 4, 782-799. [CrossRef] 
29. Sayama, K.; Yase, K.; Arakawa, H.; Asakura, K.; Tanaka, A.; Domen, K.; Onishi, T. Photocatalytic activity and reaction mechanism of Pt-intercalated $\mathrm{K}_{4} \mathrm{Nb}_{6} \mathrm{O}_{17}$ catalyst on the water splitting in carbonate salt aqueous solution. J. Photochem. Photobiol. A 1998, 114, 125-135. [CrossRef]

30. Kawai, M.; Kawai, T.; Naito, S.; Tamaru, K. The mechanism of photocatalytic reaction over Pt/TiO 2 : Production of $\mathrm{H}_{2}$ and aldehyde from gaseous alcohol and water. Chem. Phys. Lett. 1984, 110, 58-62. [CrossRef]

31. And, J.S.; Rabani, J. Photocatalytic dechlorination of aqueous carbon tetrachloride solutions in $\mathrm{TiO}_{2}$ layer systems: A chain reaction mechanism. Z. Phys. Chem. 1998, 1, 313-318.

32. Tan, T.T.Y.; Donia Beydoun, A.; Amal, R. Photocatalytic reduction of Se(vi) in aqueous solutions in $\mathrm{UV} / \mathrm{TiO} \mathrm{O}_{2}$ system: Kinetic modeling and reaction mechanism. J. Phys. Chem. B 2003, 107, 4296-4303. [CrossRef]

33. Yamazaki, S.; Toshifumi Tanimura, A.; Yoshida, A.; Hori, K. Reaction mechanism of photocatalytic degradation of chlorinated ethylenes on porous $\mathrm{TiO}_{2}$ pellets: $\mathrm{Cl}$ radical-initiated mechanism. J. Phys. Chem. A 2004, 108, 5183-5188. [CrossRef]

34. Zhao, L.H.; Itoh, K.; Murabayashi, M. Reaction mechanism of photocatalytic oxidation of trichloroethylene on $\mathrm{TiO}_{2}$ film. Chin. J. Catal. 2004, 25, 915-919.

35. Li, A.C.; Li, G.H.; Zheng, Y.; Feng, L.L.; Zheng, Y.J. Photocatalytic property and reaction mechanism of $(\mathrm{Ni}-\mathrm{Mo}) / \mathrm{TiO}_{2}$ nano thin film evaluated with congo red. Acta Phys.-Chim. Sin. 2012, 28, 457-464.

36. Moctezuma, E.; Leyva, E.; Aguilar, C.A.; Luna, R.A.; Montalvo, C. Photocatalytic degradation of paracetamol: Intermediates and total reaction mechanism. J. Hazard. Mater. 2012, 243, 130-138. [CrossRef]

37. Nishikawa, M.; Mitani, Y.; Nosaka, Y. Photocatalytic reaction mechanism of Fe(III)-grafted $\mathrm{TiO}_{2}$ studied by means of ESR spectroscopy and chemiluminescence photometry. J. Phys. Chem. C 2012, 116, 14900-14907. [CrossRef]

38. Liu, L.; Li, Y. Understanding the reaction mechanism of photocatalytic reduction of $\mathrm{CO}_{2}$ with $\mathrm{H}_{2} \mathrm{O}$ on $\mathrm{TiO}_{2}$-based photocatalysts: A review. Aerosol Air Qual. Res. 2014, 14, 453-469. [CrossRef]

39. Guzman, M.I.; Martin, S.T. Oxaloacetate-to-malate conversion by mineral photoelectrochemistry: Implications for the viability of the reductive tricarboxylic acid cycle in prebiotic chemistry. Int. J. Astrobiol. 2008, 7, 271-278. [CrossRef]

40. Zhou, R.; Guzman, M.I. $\mathrm{CO}_{2}$ reduction under periodic illumination of ZnS. J. Phys. Chem. C 2014, 118, 11649-11656. [CrossRef]

41. Kim, S.-J.; Lee, E.G.; Park, S.D.; Jeon, C.J.; Cho, Y.H.; Rhee, C.K.; Kim, W.W. Photocatalytic effects of rutile phase $\mathrm{TiO}_{2}$ ultrafine powder with high specific surface area obtained by a homogeneous precipitation process at low temperatures. J. Sol-Gel Sci. Technol. 2001, 22, 63-74. [CrossRef]

42. Liu, C.; Han, X.; Xie, S.; Kuang, Q.; Wang, X.; Jin, M.; Xie, Z.; Zheng, L. Enhancing the photocatalytic activity of anatase $\mathrm{TiO}_{2}$ by improving the specific facet-induced spontaneous separation of photogenerated electrons and holes. Chemistry 2013, 8, 282-289.

43. Kapinus, E.I.; Khalyavka, T.A.; Shimanovskaya, V.V.; Viktorova, T.I.; Strelko, V.V. Photocatalytic activity of spectro-pure titanium dioxide: Effects of crystalline structure, specific surface area and sorption properties. Int. J. Photoenergy 2014, 5, 159-166. [CrossRef]

44. Si, W.; Yang, Z.; Wang, X.; Lv, Q.; Huang, C. Fe, N-odoped graphdiyne displaying efficient oxygen reduction reaction activity. ChemSusChem 2018, 12, 173-178. [CrossRef] [PubMed]

45. Ji-Lian, L.I. The influence factors of photocatalytic oxidation cyclohexance over nano- $\mathrm{ZnFe}_{2} \mathrm{O}_{4} / \mathrm{SiO}_{2}$. J. Dalian Coll. Educ. 2001, 17, 54-55.

46. Barka, N.; Qourzal, S.; Assabbane, A.; Nounah, A.; Ait-Ichou, Y. Factors influencing the photocatalytic degradation of rhodamine b by $\mathrm{TiO}_{2}$-coated non-woven paper. J. Photochem. Photobiol. A 2008, 195, 346-351. [CrossRef]

47. Liu, H.; Pei, S.; Liu, G.; Chen, Y. Study on the influencing factors of photocatalytic degradation of X-3B aqueous solution by $\mathrm{TiO}_{2}$ fibers. Acta Sci. Circumstantiae 2012, 32, 1054-1059.

48. Hoque, M.; Guzman, M. Photocatalytic activity: Experimental features to report in heterogeneous photocatalysis. Materials 2011, 11, 1990-2000. [CrossRef] [PubMed]

49. Eggins, B.R.; Robertson, P.K.J.; Murphy, E.P.; Woods, E.; Irvine, J.T.S. Factors affecting the photoelectrochemical fixation of carbon dioxide with semiconductor colloids. J. Photochem. Photobiol. A 1998, 118, 31-40. [CrossRef]

50. Guzman, M.I.; Martin, S.T. Photo-production of lactate from glyoxylate: How minerals can facilitate energy storage in a prebiotic world. Chem. Commun. 2010, 46, 2265-2267. [CrossRef] [PubMed] 
51. Zhang, X.V.; Martin, S.T. Driving parts of krebs cycle in reverse through mineral photochemistry. J. Am. Chem. Soc. 2006, 128, 16032-16033. [CrossRef] [PubMed]

52. Zhou, R.; Guzman, M.I. Photocatalytic reduction of fumarate to succinate on ZnS mineral surfaces. J. Phys. Chem. C 2016, 120, 7349-7357. [CrossRef]

53. Fujishima, A.; Zhang, X.; Tryk, D.A. Tio photocatalysis and related surface phenomena. Surf. Sci. Rep. 2008, 63, 515-582. [CrossRef]

54. Hashimoto, K.; Irie, H.; Fujishima, A. $\mathrm{TiO}_{2}$ photocatalysis: A historical overview and future prospects. Jpn. J. Appl. Phys. 2005, 44, 8269-8285. [CrossRef]

55. Sakthivel, S.; Kisch, H. Daylight photocatalysis by carbon-modified titanium dioxide. Angew. Chem. Int. Ed. 2003, 42, 4908-4911. [CrossRef] [PubMed]

56. Linsebigler, A.L.; Lu, G.; Yates, J.T. Photocatalysis on $\mathrm{TiO}_{2}$ surfaces: Principles, mechanisms, and selected results. Chem. Rev. 1995, 95, 735-758. [CrossRef]

57. Fujishima, A.; Hashimoto, K.; Watanabe, $\mathrm{T} . \mathrm{TiO}_{2}$ photocatalysis: Fundamentals and applications. In A Revolution in Cleaning Technology; BKC, Inc.: Tokyo, Japan, 1999; pp. 14-21.

58. Woan, K.; Pyrgiotakis, G.; Sigmund, W. Photocatalytic carbon-nanotube-TiO 2 composites. Adv. Mater. 2009, 21, 2233-2239. [CrossRef]

59. Jodat, A.; Jodat, A. Photocatalytic degradation of chloramphenicol and tartrazine using $\mathrm{Ag} / \mathrm{TiO} 2$ nanoparticles. Desalin. Water Treat. 2014, 52, 2668-2677. [CrossRef]

60. Pan, J.H.; Cai, Z.; Yu, Y.; Zhao, X.S. Controllable synthesis of mesoporous $\mathrm{f}^{-\mathrm{TiO}_{2}}$ spheres for effective photocatalysis. J. Mater. Chem. 2011, 21, 11430-11438. [CrossRef]

61. Mu, W.; Herrmann, J.-M.; Pichat, P. Room temperature photocatalytic oxidation of liquid cyclohexane into cyclohexanone over neat and modified $\mathrm{TiO}_{2}$. Catal. Lett. 1989, 3, 73-84. [CrossRef]

62. Izumi, I.; Dunn, W.W.; Wilbourn, K.O.; Fan, F.R.F.; Bard, A.J. Heterogeneous photocatalytic oxidation of hydrocarbons on platinized titanium dioxide powders. J. Phys. Chem. 1980, 84, 3207-3210. [CrossRef]

63. Huang, M.; Yu, J.; Li, B.; Deng, C.; Wang, L.; Wu, W.; Dong, L.; Zhang, F.; Fan, M. Intergrowth and coexistence effects of $\mathrm{TiO}_{2}-\mathrm{SnO}_{2}$ nanocomposite with excellent photocatalytic activity. J. Alloys Compd. 2015, 629, 55-61. [CrossRef]

64. Gao, M.; Zhang, D.; Pu, X.; Ding, K.; Li, H.; Zhang, T.; Ma, H. Combustion synthesis of Bi/BiOCl composites with enhanced electron-hole separation and excellent visible light photocatalytic properties. Sep. Purif. Technol. 2015, 149, 288-294. [CrossRef]

65. Cabot, A.; Marsal, A.; Arbiol, J.; Morante, J.R. $\mathrm{Bi}_{2} \mathrm{O}_{3}$ as a selective sensing material for NO detection. Sens. Actuators B Chem. 2004, 99, 74-89. [CrossRef]

66. Sammes, N.M.; Tompsett, G.A.; Näfe, H.; Aldinger, F. Bismuth based oxide electrolytes-Structure and ionic conductivity. J. Eur. Ceram. Soc. 1999, 19, 1801-1826. [CrossRef]

67. Hameed, A.; Montini, T.; Gombac, V.; Fornasiero, P. Surface phases and photocatalytic activity correlation of $\mathrm{Bi}_{2} \mathrm{O}_{3} / \mathrm{Bi}_{2} \mathrm{O}_{4-\mathrm{x}}$ nanocomposite. J. Am. Chem. Soc. 2008, 130, 9658-9659. [CrossRef] [PubMed]

68. Qian, X.; Yue, D.; Tian, Z.; Meng, R.; Zhu, Y.; Kan, M.; Zhang, T.; Zhao, Y. Carbon quantum dots decorated $\mathrm{Bi}_{2} \mathrm{WO}_{6}$ nanocomposite with enhanced photocatalytic oxidation activity for VOCs. Appl. Catal. B Environ. 2016, 193, 16-21. [CrossRef]

69. Hu, Y.; Li, D.; Zheng, Y.; Chen, W.; He, Y.; Shao, Y.; Fu, X.; Xiao, G. BiVO $4 / \mathrm{TiO}_{2}$ nanocrystalline heterostructure: A wide spectrum responsive photocatalyst towards the highly efficient decomposition of gaseous benzene. Appl. Catal. B Environ. 2011, 104, 30-36. [CrossRef]

70. Wu, T.; Li, X.; Zhang, D.; Dong, F.; Chen, S. Efficient visible light photocatalytic oxidation of NO with hierarchical nanostructured $3 \mathrm{~d}$ flower-like $\mathrm{BiOCl}_{\mathrm{x}} \mathrm{Br}_{1-\mathrm{x}}$ solid solutions. J. Alloys Compd. 2016, 671, 318-327. [CrossRef]

71. Dong, F.; Xiong, T.; Yan, S.; Wang, H.; Sun, Y.; Zhang, Y.; Huang, H.; Wu, Z. Facets and defects cooperatively promote visible light plasmonic photocatalysis with Bi nanowires@BiOCl nanosheets. J. Catal. 2016, 344, 401-410. [CrossRef]

72. Feng, J.; Huang, H.; Yu, S.; Dong, F.; Zhang, Y. A self-sacrifice template route to iodine modified $\mathrm{BiOIO}_{3}$ : Band gap engineering and highly boosted visible-light active photoreactivity. Phys. Chem. Chem. Phys. 2016, 18, 7851-7859. [CrossRef] [PubMed] 
73. Sun, Y.; Xiong, T.; Dong, F.; Huang, H.; Cen, W. Interlayer-I-doped $\mathrm{BiOIO}_{3}$ nanoplates with an optimized electronic structure for efficient visible light photocatalysis. Chem. Commun. 2016, 52, 8243-8246. [CrossRef] [PubMed]

74. Yu, S.; Huang, H.; Dong, F.; Li, M.; Tian, N.; Zhang, T.; Zhang, Y. Synchronously achieving the plasmonic Bi metal deposition and $\mathrm{I}^{-}$doping by utilizing $\mathrm{BiOIO}_{3}$ as the self-sacrificing template for high-performance multi-functional applications. ACS Appl. Mater. Interfaces 2015, 7, 27925-27933. [CrossRef] [PubMed]

75. Ai, Z.; Ho, W.; Lee, S.; Zhang, L. Efficient photocatalytic removal of NO in indoor air with hierarchical bismuth oxybromide nanoplate microspheres under visible light. Environ. Sci. Technol. 2009, 43, 4143-4150. [CrossRef] [PubMed]

76. Dong, G.; Ho, W.; Zhang, L. Photocatalytic NO removal on BiOI surface: The change from nonselective oxidation to selective oxidation. Appl. Catal. B Environ. 2015, 168-169, 490-496. [CrossRef]

77. Zhou, Y.; Zhang, X.; Zhang, Q.; Dong, F.; Wang, F.; Xiong, Z. Role of graphene on the band structure and interfacial interaction of $\mathrm{Bi}_{2} \mathrm{WO}_{6}$ /graphene composites with enhanced photocatalytic oxidation of NO. J. Mater. Chem. A 2014, 2, 16623-16631. [CrossRef]

78. Huang, Y.; Ai, Z.; Ho, W.; Chen, M.; Lee, S. Ultrasonic spray pyrolysis synthesis of porous $\mathrm{Bi}_{2} \mathrm{WO}_{6}$ microspheres and their visible-light-induced photocatalytic removal of NO. J. Phys. Chem. C 2010, 114, 6342-6349. [CrossRef]

79. Zhao, Z.; Zhang, W.; Sun, Y.; Yu, J.; Zhang, Y.; Wang, H.; Dong, F.; Wu, Z. Bi cocatalyst $/ \mathrm{Bi}_{2} \mathrm{MoO}_{6}$ microspheres nanohybrid with SPR-promoted visible-light photocatalysis. J. Phys. Chem. C 2016, 120, 11889-11898. [CrossRef]

80. Huang, Y.; Wang, W.; Zhang, Q.; Cao, J.J.; Huang, R.J.; Ho, W.; Lee, S.C. In situ fabrication of $\alpha-\mathrm{Bi}_{2} \mathrm{O}_{3} /(\mathrm{BiO})_{2} \mathrm{CO}_{3}$ nanoplate heterojunctions with tunable optical property and photocatalytic activity. Sci. Rep. 2016, 6, 23435-23443. [CrossRef]

81. Xiong, T.; Wen, M.; Dong, F.; Yu, J.; Han, L.; Lei, B.; Zhang, Y.; Tang, X.; Zang, Z. Three dimensional Z-scheme $(\mathrm{BiO})_{2} \mathrm{CO}_{3} / \mathrm{MoS}_{2}$ with enhanced visible light photocatalytic No removal. Appl. Catal. B Environ. 2016, 199, 87-95. [CrossRef]

82. Feng, X.; Zhang, W.; Deng, H.; Ni, Z.; Dong, F.; Zhang, Y. Efficient visible light photocatalytic NOx removal with cationic ag clusters-grafted $(\mathrm{BiO})_{2} \mathrm{CO}_{3}$ hierarchical superstructures. J. Hazard. Mater. 2017, 322, $223-232$. [CrossRef] [PubMed]

83. Xiong, T.; Dong, X.A.; Huang, H.; Cen, W.; Zhang, Y.; Dong, F. Single precursor mediated-synthesis of bi semimetal deposited n-doped $(\mathrm{BiO})_{2} \mathrm{CO}_{3}$ superstructures for highly promoted photocatalysis. ACS Sustain. Chem. Eng. 2016, 4, 2969-2979. [CrossRef]

84. Dong, F.; Li, P.; Zhong, J.; Liu, X.; Zhang, Y.; Cen, W.; Huang, H. Simultaneous Pd ${ }^{2+}$ doping and Pd metal deposition on $(\mathrm{BiO})_{2} \mathrm{CO}_{3}$ microspheres for enhanced and stable visible light photocatalysis. Appl. Catal. A Gen. 2016, 510, 161-170. [CrossRef]

85. Kim, H.G.; Hwang, D.W.; Lee, J.S. An undoped, single-phase oxide photocatalyst working under visible light. J. Am. Chem. Soc. 2004, 126, 8912-8913. [CrossRef]

86. Papp, J.; Shen, H.S.; Kershaw, R.; Dwight, K.; Wold, A. Titanium(IV) oxide photocatalysts with palladium. Chem. Mater. 1993, 5, 284-288. [CrossRef]

87. Amano, F.; Yamakata, A.; Nogami, K.; Osawa, M.; Ohtani, B. Visible light responsive pristine metal oxide photocatalyst: Enhancement of activity by crystallization under hydrothermal treatment. J. Am. Chem. Soc. 2008, 130, 17650-17651. [CrossRef] [PubMed]

88. Kroll, V.; Swaan, H.; Lacombe, S.; Mirodatos, C. Methane reforming reaction with carbon dioxide over $\mathrm{Ni} / \mathrm{SiO}_{2}$ catalyst: II. A mechanistic study. J. Catal. 1996, 164, 387-398. [CrossRef]

89. Du, W.P.; Li, Z.; Leng, W.H.; Xu, Y.M. Photocatalytic reduction of silver ions on ferric oxides and ferric hydroxides. Acta Phys. Chim. Sin. 2009, 25, 1530-1534.

90. Sun, Z.; Li, L.; Yang, H.; Zhou, D.; Li, H. Photocatalytic reduction of silver ion probe on nano titanium dioxide. J. Xinyang Norm. Univ. 2016, 29, 79-83.

91. Zare, K. Study of photooxidative degradation of reactive dyes from aqueous solutions by UV/ C102 process. J. Phys. Theor. Chem. 2006, 3, 51-62.

92. Ercan, Ö.; Deniz, S.; Yetimoğlu, E.K.; Aydın, A. Degradation of reactive dyes using advanced oxidation method. Clean Soil Air Water 2015, 43, 1031-1036. [CrossRef]

93. Jablonski, M.R.; Ranicke, H.B. Novel photo-fenton oxidation with sand and carbon filtration of high concentration reactive dyes both with and without biodegradation. J. Text. Sci. Eng. 2016, 6, 2-17. 
94. And, K.M.; Domen, K. New non-oxide photocatalysts designed for overall water splitting under visible light. J. Phys. Chem. C 2007, 111, 7851-7861.

95. Sato, J.; Saito, N.; Yamada, Y.; Maeda, K.; Takata, T.; Kondo, J.N.; Hara, M.; Kobayashi, H.; Domen, K.; Inoue, $\mathrm{Y} . \mathrm{RuO}_{2}$-loaded $\beta-\mathrm{Ge}_{3} \mathrm{~N}_{4}$ as a non-oxide photocatalyst for overall water splitting. J. Am. Chem. Soc. 2005, 127, 4150-4151. [CrossRef] [PubMed]

96. Cheng, J.; Pan, Y.; Zhu, J.; Li, Z.; Pan, J.; Ma, Z. Hybrid network cus monolith cathode materials synthesized via facile in situ melt-diffusion for Li-ion batteries. J. Power Sources 2014, 257, 192-197. [CrossRef]

97. Chang, L.; He, X.; Chen, L.; Zhang, Y. Mercaptophenylboronic acid-capped Mn-doped ZnS quantum dots for highly selective and sensitive fluorescence detection of glycoproteins. Sens. Actuators B Chem. 2017, 243, 72-77. [CrossRef]

98. Zhang, X.V.; Ellery, S.P.; Friend, C.M.; Holland, H.D.; Michel, F.M.; Schoonen, M.A.; Martin, S.T. Photodriven reduction and oxidation reactions on colloidal semiconductor particles: Implications for prebiotic synthesis. J. Photochem. Photobiol. A 2007, 185, 301-311. [CrossRef]

99. Khanchandani, S.; Kundu, S.; Patra, A.; Ganguli, A.K. Shell thickness dependent photocatalytic properties of $\mathrm{ZnO} / \mathrm{CdS}$ core-shell nanorods. J. Phys. Chem. C 2012, 116, 23653-23662. [CrossRef]

100. Kudo, A.; Miseki, Y. Heterogeneous photocatalyst materials for water splitting. Chem. Soc. Rev. 2009, 38, 253-278. [CrossRef]

101. Zheng, N.-C.; Ouyang, T.; Chen, Y.; Wang, Z.; Chen, D.-Y.; Liu, Z.-Q. Ultrathin CdS shell-sensitized hollow s-doped $\mathrm{CeO}_{2}$ spheres for efficient visible-light photocatalysis. Catal. Sci. Technol. 2019, 9, 1357-1364. [CrossRef]

102. Li, X.; Wen, J.; Low, J.; Fang, Y.; Yu, J. Design and fabrication of semiconductor photocatalyst for photocatalytic reduction of $\mathrm{CO}_{2}$ to solar fuel. Sci. China Mater. 2014, 57, 70-100. [CrossRef]

103. $\mathrm{Xu}, \mathrm{Y}$.; Schoonen, M.A.A. The absolute energy positions of conduction and valence bands of selected semiconducting minerals. Am. Miner. 2000, 85, 543-556. [CrossRef]

104. Córdova, R.; Gómez, H.; Schrebler, R.; Cury, P.; Orellana, M.; Grez, P.; Leinen, D.; Río, R.D. Electrosynthesis and electrochemical characterization of a thin phase of CuxS $(x \rightarrow 2)$ on ITO electrode. Langmuir 2002, 18, 8647-8654. [CrossRef]

105. Wen, P.L.; Ling, C.T.W.; Ang, S.; Yee Low, H. Phase-selective synthesis of copper sulfide nanocrystals. Chem. Mater. 2006, 18, 6170-6177.

106. Erokhina, S.; Erokhin, V.; Nicolini, C. Microstructure origin of the conductivity differences in aggregated CuS films of different thickness. Langmuir 2003, 19, 766-771. [CrossRef]

107. Gorai, S.; Ganguli, D.; Chaudhuri, S. Synthesis of copper sulfides of varying morphologies and stoichiometries controlled by chelating and nonchelating solvents in a solvothermal process. Cryst. Growth Des. 2013, 5 , 1-12. [CrossRef]

108. Bessekhouad, Y.; Robert, D.; Weber, J.V. $\mathrm{Bi}_{2} \mathrm{~S}_{3} / \mathrm{TiO}_{2}$ and $\mathrm{CdS} / \mathrm{TiO}_{2}$ heterojunctions as an available configuration for photocatalytic degradation of organic pollutant. J. Photochem. Photobiol. A 2004, 163, 569-580. [CrossRef]

109. Mills, A.; O'Rourke, C.; Moore, K. Powder semiconductor photocatalysis in aqueous solution: An overview of kinetics-based reaction mechanisms. J. Photochem. Photobiol. A 2015, 310, 66-105. [CrossRef]

110. Kanemoto, M.; Shiragami, T.; Pac, C.; Yanagida, S.; Kanemoto, M.; Shiragami, T.; Pac, C. Semiconductor photocatalysis. Effective photoreduction of carbon dioxide catalyzed by ZnS quantum crystallites with low density of surface defects. J. Phys. Chem. 1992, 96, 3521-3526. [CrossRef]

111. Zhang, H.; Gilbert, B.; Huang, F.; Banfield, J.F. Water-driven structure transformation in nanoparticles at room temperature. Nature 2003, 424, 1025-1029. [CrossRef] [PubMed]

112. Henglein, A.; Gutierrez, M.; Fischer, C.H. Photochemistry of colloidal metal sulfides 6 . Kinetics of interfacial reactions at ZnS-particles. Ber. Bunsenges. Phys. Chem. 1984, 88, 170-175. [CrossRef]

113. Xu, J.F.; Ji, W.; Lin, J.Y.; Tang, S.H.; Du, Y.W. Preparation of ZnS nanoparticles by ultrasonic radiation method. Appl. Phys. A 1998, 66, 639-641. [CrossRef]

114. Lenggoro, I.W.; Okuyama, K.; Mora, J.F.D.L.; Tohge, N. Preparation of ZnS nanoparticles by electrospray pyrolysis. J. Aerosol. Sci. 2000, 31, 121-136. [CrossRef]

115. Suliman, A.E.; Tang, Y.; Liang, X. Preparation of ZnO nanoparticles and nanosheets and their application to dye-sensitized solar cells. Sol. Energy Mater. Sol. C 2007, 91, 1658-1662. [CrossRef] 
116. Reddy, P.L.; Deshmukh, K.; Chidambaram, K.; Ali, M.M.N.; Sadasivuni, K.K.; Kumar, Y.R.; Lakshmipathy, R.; Pasha, S.K.K. Dielectric properties of polyvinyl alcohol (PVA) nanocomposites filled with green synthesized zinc sulphide (ZnS) nanoparticles. J. Mater. Sci. Mater. Electron. 2019, 30, 1-12. [CrossRef]

117. Johne, P.; Kisch, H. Photoreduction of carbon dioxide catalysed by free and supported zinc and cadmium sulphide powders. J. Photochem. Photobiol. A 1997, 111, 223-228. [CrossRef]

118. Moore, D.F.; Ding, Y.; Wang, Z.L. Crystal orientation-ordered ZnS nanowire bundles. J. Am. Chem. Soc. 2004, 126, 14372-14373. [CrossRef] [PubMed]

119. Hsu, Y.J.; Lu, S.Y. One-step preparation of coaxial CdS-ZnS nanowires. Chem. Commun. 2004, 15, $2102-2103$. [CrossRef]

120. Xu, X.J.; Fei, G.T.; Yu, W.H.; Wang, X.W.; Chen, L.; Zhang, L.D. Preparation and formation mechanism of ZnS semiconductor nanowires made by the electrochemical deposition method. Nanotechnology 2006, 17, 426-429. [CrossRef]

121. Guo-Ping, L.I. Hydrothermal preparation of ZnS nanowires. Chin. J. Inorg. Chem. 2007, 23, 1864-1868.

122. Khanlary, M.R.; Alijarahi, S.; Reyhani, A. Growth temperature dependence of VLS-grown ultra-long ZnS nanowires prepared by CVD method. J. Theor. Appl. Phys. 2018, 12, 121-126. [CrossRef]

123. Wang, Z.L.; Wang, X.; Gao, P.; Li, J.; Summers, C.J. Rectangular porous ZnO-ZnS nanocables and ZnS nanotubes. Adv. Mater. 2002, 14, 1732-1735. [CrossRef]

124. Lv, R.T.; Cao, C.B.; Guo, Y.J.; Zhu, H.S. Preparation of ZnS nanotubes via surfactant micelle-template inducing reaction. J. Mater. Sci. 2004, 39, 1575-1578. [CrossRef]

125. Kim, M.R.; Ahn, S.J.; Jang, D.J. Preparation and characterization of titania/ZnS core-shell nanotubes. J. Nanosci. Nanotechnol. 2006, 6, 180-184. [PubMed]

126. Wang, Z.; Zhang, H.; Cao, H.; Wang, L.; Wan, Z.; Hao, Y.; Wang, X. Facile preparation of ZnS/CdS core/shell nanotubes and their enhanced photocatalytic performance. Int. J. Hydrogen Energy 2017, 42, 17394-17402. [CrossRef]

127. Fang, X.-S.; Ye, C.-H.; Peng, X.-S.; Wang, Y.-H.; Wu, Y.-C.; Zhang, L.-D. Large-scale synthesis of ZnS nanosheets by the evaporation of ZnS nanopowders. J. Cryst. Growth 2004, 263, 263-268. [CrossRef]

128. Srinivasan, N.; Thirumaran, S.; Ciattini, S. Preparation of ZnS nanosheets from (2,2'-bipyridine)bis(1,2,3,4tetrahydroquinolinecarbodithioato-S,S')zinc(II). Spectrochim. Acta A 2013, 102, 263-268. [CrossRef] [PubMed]

129. Wu, Q.; Cao, H.; Zhang, S.; Zhang, X.; Rabinovich, D. Generation and optical properties of monodisperse wurtzite-type ZnS microspheres. Inorg. Chem. 2006, 45, 7316-7322. [CrossRef] [PubMed]

130. Shi, Y.; Chen, J.; Shen, P. ZnS micro-spheres and flowers: Chemically controlled synthesis and template use in fabricating MS (shell)/ZnS (core) and MS (M = Pb, Cu) hollow microspheres. J. Alloys Compd. 2007, 441, 337-343. [CrossRef]

131. Hu, J.S.; Ren, L.L.; Guo, Y.G.; Liang, H.P.; Cao, A.M.; Dr, L.J.W.; Dr, C.L.B. Mass production and high photocatalytic activity of ZnS nanoporous nanoparticles. Angew. Chem. 2010, 44, 1269-1273. [CrossRef] [PubMed]

132. Zhang, J.; Liu, S.; Yu, J.; Jaroniec, M. A simple cation exchange approach to Bi-doped ZnS hollow spheres with enhanced UV and visible-light photocatalytic $\mathrm{H}_{2}$-production activity. J. Mater. Chem. 2011, 21, 14655-14662. [CrossRef]

133. Zhang, J.; Yu, J.; Zhang, Y.; Li, Q.; Gong, J.R. Visible light photocatalytic $\mathrm{H}_{2}$-production activity of CuS/ZnS porous nanosheets based on photoinduced interfacial charge transfer. Nano Lett. 2011, 11, 4774-4779. [CrossRef] [PubMed]

134. Zhang, J.; Wang, Y.; Zhang, J.; Lin, Z.; Huang, F.; Yu, J. Enhanced photocatalytic hydrogen production activities of Au-loaded ZnS flowers. ACS Appl. Mater. Interfaces 2013, 5, 1031-1037. [CrossRef] [PubMed]

135. Liu, A.Y.; Cohen, M.L. Prediction of new low compressibility solids. Science 1989, 245, 841-842. [CrossRef] [PubMed]

136. Niu, C.; Lu, Y.Z.; Lieber, C.M. Experimental realization of the covalent solid carbon nitride. Science 1993, 261, 334-337. [CrossRef]

137. Cao, S.; Low, J.; Yu, J.; Jaroniec, M. Polymeric photocatalysts based on graphitic carbon nitride. Adv. Mater. 2015, 46, 2150-2176. [CrossRef]

138. Teter, D.M.; Hemley, R.J. Low-compressibility carbon nitrides. Science 1996, 271, 53-55. [CrossRef] 
139. Wang, X.; Maeda, K.; Thomas, A.; Takanabe, K.; Xin, G.; Carlsson, J.M.; Domen, K.; Antonietti, M. A metal-free polymeric photocatalyst for hydrogen production from water under visible light. Nat. Mater. 2009, 8, 76-80. [CrossRef]

140. Fina, F.; Callear, S.K.; Carins, G.M.; Irvine, J.T.S. Structural investigation of graphitic carbon nitride via xrd and neutron diffraction. Chem. Mater. 2015, 27, 2612-2618. [CrossRef]

141. Wang, X.; Maeda, K.; Chen, X.; Takanabe, K.; Domen, K.; Hou, Y.; Fu, X.; Antonietti, M. Polymer semiconductors for artificial photosynthesis: Hydrogen evolution by mesoporous graphitic carbon nitride with visible light. J. Am. Chem. Soc. 2009, 131, 1680-1681. [CrossRef]

142. Wang, Y.; Wang, X.; Antonietti, M. Polymeric graphitic carbon nitride as a heterogeneous organocatalyst: From photochemistry to multipurpose catalysis to sustainable chemistry. Angew. Chem. Int. Ed. 2012, 51, 68-89. [CrossRef] [PubMed]

143. Zhu, J.; Xiao, P.; Li, H.; Carabineiro, S.A. Graphitic carbon nitride: Synthesis, properties, and applications in catalysis. ACS Appl. Mater. Interfaces 2014, 6, 16449-16465. [CrossRef] [PubMed]

144. Cui, Y.; Tang, Y.; Wang, X. Template-free synthesis of graphitic carbon nitride hollow spheres for photocatalytic degradation of organic pollutants. Mater. Lett. 2015, 161, 197-200. [CrossRef]

145. Maeda, K.; Kuriki, R.; Zhang, M.; Wang, X.; Ishitani, O. The effect of the pore-wall structure of carbon nitride on photocatalytic $\mathrm{CO}_{2}$ reduction under visible light. J. Mater. Chem. A 2014, 2, 15146-15151. [CrossRef]

146. Wang, W.; Yu, J.C.; Xia, D.; Wong, P.K.; Li, Y. Graphene and g- $\mathrm{C}_{3} \mathrm{~N}_{4}$ nanosheets cowrapped elemental $\alpha$-sulfur as a novel metal-free heterojunction photocatalyst for bacterial inactivation under visible-light. Environ. Sci. Technol. 2013, 47, 8724-8732. [CrossRef] [PubMed]

147. Lv, Q.; Si, W.; He, J.; Sun, L.; Zhang, C.; Wang, N.; Yang, Z.; Li, X.; Wang, X.; Deng, W. Selectively nitrogen-doped carbon materials as superior metal-free catalysts for oxygen reduction. Nat. Commun. 2018, 9, 3376-3386. [CrossRef]

148. Liu, H.; Zhang, Z.-G.; He, H.-W.; Wang, X.-X.; Zhang, J.; Zhang, Q.-Q.; Tong, Y.-F.; Liu, H.-L.; Ramakrishna, S.; Yan, S.-Y. One-step synthesis heterostructured g- $\mathrm{C}_{3} \mathrm{~N}_{4} / \mathrm{TiO}_{2}$ composite for rapid degradation of pollutants in utilizing visible light. Nanomaterials 2018, 8, 842. [CrossRef] [PubMed]

149. Ward, M.D.; White, J.R.; Bard, A.J. Electrochemical investigation of the energetics of particulate titanium dioxide photocatalysts. The methyl viologen-acetate system. J. Am. Chem. Soc. 1983, 105, 27-31. [CrossRef]

150. Gunti, S. Enhanced Visible Light Photocatalytic Remediation of Organics in Water Using Zinc Oxide and Titanium Oxide Nanostructures. 2017. Available online: https://scholarcommons.usf.edu/etd/6852/ (accessed on 16 September 2018).

151. Jongh, P.E.D.; Vanmaekelbergh, D.; Kelly, J.J. $\mathrm{Cu}_{2} \mathrm{O}$ : A catalyst for the photochemical decomposition of water? Chem. Commun. 1999, 12, 1069-1070. [CrossRef]

152. Finlayson, M.F.; Wheeler, B.L.; Kakuta, N.; Park, K.H.; Bard, A.J.; Campion, A.; Fox, M.A.; Webber, S.E.; White, J.M. Determination of flat-band position of cadmium sulfide crystals, films, and powders by photocurrent and impedance techniques, photoredox reaction mediated by intragap states. J. Phys. Chem. 1985, 89, 5676-5681. [CrossRef]

153. Zhang, J.; Chen, X.; Takanabe, K.; Maeda, K.; Domen, K.; Epping, J.D.; Fu, X.; Antonietti, M.; Wang, X. Synthesis of a carbon nitride structure for visible-light catalysis by copolymerization. Angew. Chem. Int. Ed. 2010, 49, 441-444. [CrossRef] [PubMed]

154. Yan, S.C.; Lv, S.B.; Li, Z.S.; Zou, Z.G. Organic-inorganic composite photocatalyst of g- $\mathrm{C}_{3} \mathrm{~N}_{4}$ and TaON with improved visible light photocatalytic activities. Dalton Trans. 2010, 39, 1488-1491. [CrossRef] [PubMed]

155. Chun, W.J.; Ishikawa, A.; Fujisawa, H.; Takata, T.; Kondo, J.N.; Hara, M.; Kawai, M.; Matsumoto, Y.; Domen, K. Conduction and valence band positions of $\mathrm{Ta}_{2} \mathrm{O}_{5}, \mathrm{TaON}$, and $\mathrm{Ta}_{3} \mathrm{~N}_{5}$ by ups and electrochemical methods. J. Phys. Chem. B 2003, 34, 1798-1803. [CrossRef]

156. Memar, A.; Chi, M.P.; Tade, M.O. Influence of surfactants on $\mathrm{Fe}_{2} \mathrm{O}_{3}$ nanostructure photoanode. Int. J. Hydrogen Energy 2012, 37, 16835-16843. [CrossRef]

157. Li, Z.Q.; Chen, X.T.; Xue, Z.L. Microwave-assisted synthesis and photocatalytic properties of flower-like $\mathrm{Bi}_{2} \mathrm{WO}_{6}$ and $\mathrm{Bi}_{2} \mathrm{O}_{3}-\mathrm{Bi}_{2} \mathrm{WO}_{6}$ composite. J. Colloid Interface Sci. 2013, 394, 69-77. [CrossRef] [PubMed]

158. Kisch, H. Visible light induced photoelectrochemical properties of n-BiVO and n- $\mathrm{BiVO} 4 / \mathrm{p}_{4}-\mathrm{Co}_{3} \mathrm{O}_{4}$. J. Phys. Chem. C 2008, 112, 548-554.

159. Hardee, K.L.; Bard, A.J. Semiconductor electrodes. X. Photoelectrochemical behavior of several polycrystalline metal oxide electrodes in aqueous solutions. J. Electrochem. Soc. 1977, 124, 215-224. [CrossRef] 
160. Yi, Z.; Ye, J.; Kikugawa, N.; Kako, T.; Ouyang, S.; Stuartwilliams, H.; Yang, H.; Cao, J.; Luo, W.; Li, Z. An orthophosphate semiconductor with photooxidation properties under visible-light irradiation. Nat. Mater. 2010, 9, 559-564. [CrossRef]

161. Doshi, J.; Reneker, D.H. Electrospinning process and applications of electrospun fibers. J. Electrostat. 1995, 35, 151-160. [CrossRef]

162. Huang, Z.M.; Zhang, Y.Z.; Kotaki, M.; Ramakrishna, S. A review on polymer nanofibers by electrospinning and their applications in nanocomposites. Comp. Sci. Technol. 2003, 63, 2223-2253. [CrossRef]

163. Greiner, A.; Wendorff, J.H. Electrospinning: A fascinating method for the preparation of ultrathin fibers. Angew. Chem. Int. Ed. 2007, 46, 5670-5703. [CrossRef] [PubMed]

164. Sill, T.J.; Recum, H.A.V. Electrospinning: Applications in drug delivery and tissue engineering. Biomaterials 2008, 29, 1989-2006. [CrossRef] [PubMed]

165. Bhardwaj, N.; Kundu, S.C. Electrospinning: A fascinating fiber fabrication technique. Biotechnol. Adv. 2010, 28, 325-347. [CrossRef] [PubMed]

166. Li, D.; Xia, Y. Electrospinning of nanofibers: Reinventing the wheel? Adv. Mater. 2010, 16, 1151-1170. [CrossRef]

167. Zhang, Z.G.; Liu, H.; Zhang, B.; Zhang, J.; Liu, R.Z.; Ning, X.; Long, Y.Z. Synthesis and application of highly ordered arrays of $\mathrm{TiO}_{2}$ rods grown on electrospun PVDF fibers. Mater. Res. Express 2017, 4, 075907. [CrossRef]

168. Liu, H.; Zhang, Z.G.; Wang, X.X.; Nie, G.D.; Zhang, J.; Zhang, S.X.; Cao, N.; Yan, S.Y.; Long, Y.Z. Highly flexible $\mathrm{Fe}_{2} \mathrm{O}_{3} / \mathrm{TiO}_{2}$ composite nanofibers for photocatalysis and utraviolet detection. J. Phys. Chem. Solids 2018, 121, 236-246. [CrossRef]

169. Liu, Y.J.; Zhang, H.D.; Zhang, J.; Li, S.; Zhang, J.C.; Zhu, J.W.; Gong, M.G.; Wang, X.X.; Long, Y.Z.; Liu, Y.J. Effects of ce doping and humidity on UV sensing properties of electrospun ZnO nanofibers. J. Appl. Phys. 2017, 122, 105102. [CrossRef]

170. Zhang, H.-D.; Liu, Y.-J.; Zhang, J.; Zhu, J.-W.; Qin, Q.-H.; Zhao, C.-Z.; Li, X.; Zhang, J.-C.; Long, Y.-Z. Electrospun $\mathrm{ZnO} / \mathrm{SiO}_{2}$ hybrid nanofibers for flexible pressure sensor. J. Phys. D Appl. Phys. 2018, 51, 085102. [CrossRef]

171. Zhang, Z.-G.; Liu, H.; Wang, X.-X.; Zhang, J.; Yu, M.; Ramakrishna, S.; Long, Y.-Z. One-step low temperature hydrothermal synthesis of flexible $\mathrm{TiO}_{2} / \mathrm{PVDF} @ \mathrm{MoS}_{2}$ core-shell heterostructured fibers for visible-light-driven photocatalysis and self-cleaning. Nanomaterials 2019, 9, 431. [CrossRef] [PubMed]

172. Wang, X.; Song, W.-Z.; You, M.-H.; Zhang, J.; Yu, M.; Fan, Z.; Ramakrishna, S.; Long, Y.-Z. Bionic single-electrode electronic skin unit based on piezoelectric nanogenerator. ACS Nano 2018, 12, 8588-8596. [CrossRef]

173. Chen, S.; Liu, G.-S.; He, H.-W.; Zhou, C.-F.; Yan, X.; Zhang, J.-C. Physical structure induced hydrophobicity analyzed from electrospinning and coating polyvinyl butyral films. Adv. Condens. Matter Phys. 2019, 2019, 1-5. [CrossRef]

174. Liu, G.-S.; Yan, X.; Yan, F.-F.; Chen, F.-X.; Hao, L.-Y.; Chen, S.-J.; Lou, T.; Ning, X.; Long, Y.-Z. In situ electrospinning iodine-based fibrous meshes for antibacterial wound dressing. Nanoscale Res. Lett. 2018, 13, 309-315. [CrossRef] [PubMed]

175. Yan, X.; You, M.-H.; Lou, T.; Yu, M.; Zhang, J.-C.; Gong, M.-G.; Lv, F.-Y.; Huang, Y.-Y.; Long, Y.-Z. Colorful hydrophobic poly (vinyl butyral)/cationic dye fibrous membranes via a colored solution electrospinning process. Nanoscale Res. Lett. 2016, 11, 540-548. [CrossRef] [PubMed]

176. Yan, X.; Yu, M.; Han, W.-P.; You, M.-H.; Zhang, J.-C.; Dong, R.-H.; Zhang, H.-D.; Long, Y.-Z. Fabrication and formation mechanism of closed-loop fibers by electrospinning with a tip collector. Chin. Phys. B 2016, 25, 078106. [CrossRef]

177. Cai, M.; He, H.; Zhang, X.; Yan, X.; Li, J.; Chen, F.; Yuan, D.; Ning, X. Efficient synthesis of PVDF/PI side-by-side bicomponent nanofiber membrane with enhanced mechanical strength and good thermal stability. Nanomaterials 2019, 9, 39. [CrossRef] [PubMed]

178. Gait, M.J.; Sheppard, R.C. Rapid synthesis of oligodeoxyribonucleotides: A new solid-phase method. Nucleic Acids Res. 1977, 4, 1135-1158. [CrossRef] [PubMed]

179. Nikiforov, T.T.; Rendie, R.B.; Goelet, P.; Rogers, Y.; Kotewicz, M.L.; Anderson, S.; Trainor, G.L.; Knapp, M.R. Genetic bit analysis: A solid phase method for typing single nucleotide polymorphisms. Nucleic Acids Res. 1994, 22, 4167-4175. [CrossRef] [PubMed] 
180. Roberts, D.D.; Pollien, P.; Milo, C. Solid-phase microextraction method development for headspace analysis of volatile flavor compounds. J. Agric. Food Chem. 2000, 48, 2430-2437. [CrossRef] [PubMed]

181. Feng, P.; Wang, W.; Wang, K.; Cheng, S.; Jiang, $\mathrm{K} . \mathrm{Na}_{3} \mathrm{~V}_{2}\left(\mathrm{PO}_{4}\right)_{3} / \mathrm{C}$ synthesized by facile solid-phase method assisted with agarose as high-performance cathode for sodium-ion battery. J. Mater. Chem. A 2017, 5, 10261-10268. [CrossRef]

182. Yang, S.; Höti, N.; Yang, W.; Liu, Y.; Chen, L.; Li, S.; Zhang, H. Simultaneous analyses of n-linked and o-linked glycans of ovarian cancer cells using solid-phase chemoenzymatic method. Clin. Proteom. 2017, 14, 3-13. [CrossRef]

183. Premkumar, P.A.; Bahlawane, N.; Reiss, G.; Kohse-Höinghaus, K. CVD of metals using alcohols and metal acetylacetonates, part ii: Role of solvent and characterization of metal films made by pulsed spray evaporation CVD. Chem. Vap. Depos. 2010, 13, 227-231. [CrossRef]

184. Duan, X.; Chen, G.; Guo, L.A.; Zhu, Y.; Ye, H.; Wu, Y. A template-free CVD route to synthesize hierarchical porous ZnO films. Superlattice Microstruct. 2015, 88, 501-507. [CrossRef]

185. Kong, Y.C.; Yu, D.P.; Zhang, B.; Fang, W.; Feng, S.Q. Ultraviolet-emitting ZnO nanowires synthesized by a physical vapor deposition approach. Appl. Phys. Lett. 2001, 78, 407-409. [CrossRef]

186. Helmersson, U.; Lattemann, M.; Bohlmark, J.; Ehiasarian, A.P.; Gudmundsson, J.T. Ionized physical vapor deposition (IPVD): A review of technology and applications. Thin Solid Film 2006, 513, 1-24. [CrossRef]

187. Niu, C. Hybrid Ionized Physical Vapor Deposition of via and Trench Liners. U.S. Patent EP20070251306, 4 October 2007.

188. Richter, G.; Hillerich, K.; Gianola, D.S.; Mönig, R.; Kraft, O.; Volkert, C.A. Ultrahigh strength single crystalline nanowhiskers grown by physical vapor deposition. Nano Lett. 2009, 9, 3048-3052. [CrossRef] [PubMed]

189. Fischer, R.J.; Cho, A.Y. Molecular beam epitaxy. Prog. Solid State Chem. 1980, 10, 157-191.

190. Beydoun, D.; Amal, R.; Low, G.; Mcevoy, S. Role of nanoparticles in photocatalysis. J. Nanopart. Res. 1999, 1, 439-458. [CrossRef]

191. Andreev, B.; Chalkov, V.; Gusev, O.; Emel'Yanov, A.; Krasil'Nik, Z.; Kuznetsov, V.; Pak, P.; Shabanov, V.; Shengurov, V.; Shmagin, V. Realization of photo- and electroluminescent Si: Er structures by the method of sublimation molecular beam epitaxy. Nanotechnology 2002, 13, 97-102. [CrossRef]

192. Look, D.C.; Reynolds, D.C.; Litton, C.W.; Jones, R.L. Characterization of homoepitaxial p-type ZnO grown by molecular beam epitaxy. Appl. Phys. Lett. 2002, 81, 1830-1832. [CrossRef]

193. Wang, D.; Pierre, A.; Kibria, M.G.; Cui, K.; Han, X.; Bevan, K.H.; Guo, H.; Paradis, S.; Hakima, A.R.; $\mathrm{Mi}, \mathrm{Z}$. Wafer-level photocatalytic water splitting on gan nanowire arrays grown by molecular beam epitaxy. Nano Lett. 2011, 11, 2353-2357. [CrossRef]

194. Qin, S.; Zhou, H.X. Fast method for computing chemical potentials and liquid-liquid phase equilibria of macromolecular solutions. J. Phys. Chem. B 2016, 120, 8164-8174. [CrossRef] [PubMed]

195. Khaliullina, A.S.; Dunyushkina, L.A. Preparation of a film electrolyte based on calcium zirconate on a porous electrode by a chemical liquid-phase method. Russ. J. Appl. Chem. 2017, 90, 1674-1679. [CrossRef]

196. Zhao, L.; Liu, J.; Wang, R.; Li, Y.; Wang, L.; Gai, G. Preparation technology of magnesium hydroxide flame retardant by liquid phase chemical method. Inorg. Chem. Ind. 2018, 50, 8-11.

197. Navio, J.; Marchena, F.; Macias, M.; Sanchez-Soto, P.; Pichat, P. Formation of zirconium titanate powder from a Sol-gel prepared reactive precursor. J. Mater. Sci. 1992, 27, 2463-2467. [CrossRef]

198. Liu, Z.; Zhou, Y.; Li, Z.; Wang, Y.; Ge, C. Preparation and characterization of (metal, nitrogen)-codoped $\mathrm{TiO}_{2}$ by $\mathrm{TiCl}_{4}$ sol-gel auto-igniting synthesis. Rare Met. 2007, 26, 263-270. [CrossRef]

199. Gong, D.; Grimes, C.A.; Varghese, O.K.; Hu, W.; Singh, R.S.; Chen, Z.; Dickey, E.C. Titanium oxide nanotube arrays prepared by anodic oxidation. J. Mater. Res. 2011, 16, 3331-3334. [CrossRef]

200. Tsuchiya, H.; Macak, J.M.; Taveira, L.; Balaur, E.; Ghicov, A.; Sirotna, K.; Schmuki, P. Self-organized $\mathrm{TiO}_{2}$ nanotubes prepared in ammonium fluoride containing acetic acid electrolytes. Electrochem. Commun. 2005, 7, 576-580. [CrossRef]

201. El-Shazly, A.N.; Rashad, M.M.; Abdel-Aal, E.A.; Ibrahim, I.A.; El-Shahat, M.F.; Shalan, A.E. Nanostructured $\mathrm{ZnO}$ photocatalysts prepared via surfactant assisted co-precipitation method achieving enhanced photocatalytic activity for the degradation of methylene blue dyes. J. Environ. Chem. Eng. 2016, 4, 3177-3184. [CrossRef] 
202. Jiang, X.; Zhao, X.; Duan, L.; Shen, H.; Liu, H.; Hou, T.; Wang, F. Enhanced photoluminescence and

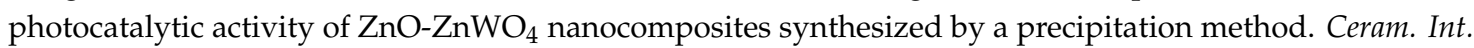
2016, 42, 15160-15165. [CrossRef]

203. Yin, L.; Zhang, D.; Wang, D.; Kong, X.; Huang, J.; Wang, F.; Wu, Y. Size dependent photocatalytic activity of ZnS nanostructures prepared by a facile precipitation method. Mater. Sci. Eng. B 2016, 208, 15-21. [CrossRef]

204. Meng, Q.; Wang, J. Synthesis of Fe-doped ZnO by parallel flow precipitation method and its photocatalytic denitrification performance. CIESC J. 2017, 68, 437-443.

205. Nouri, M.; Saray, A.M.; Azimi, H.R.; Yousefi, R. High solar-light photocatalytic activity of using $\mathrm{Cu}_{3} \mathrm{Se}_{2} / \mathrm{RGO}$ nanocomposites synthesized by a green co-precipitation method. Solid State Sci. 2017, 73, 7-12. [CrossRef]

206. Lassoued, M.S.; Lassoued, A.; Ammar, S.; Gadri, A.; Salah, A.B.; García-Granda, S. Synthesis and characterization of co-doped nano- $\mathrm{TiO}_{2}$ through co-precipitation method for photocatalytic activity. J. Mater. Sci. Mater. Electron. 2018, 29, 8914-8922. [CrossRef]

207. Begum, N.S.; Ahmed, H.M.F.; Gunashekar, K.R. Effects of Ni doping on photocatalytic activity of $\mathrm{TiO}_{2}$ thin films prepared by liquid phase deposition technique. Bull. Mater. Sci. 2008, 31, 747-751. [CrossRef]

208. Shen, X.; Zhu, L.; Yu, H.; Tang, H.; Liu, S.; Li, W. Selective photocatalysis on molecular imprinted $\mathrm{TiO}_{2}$ thin films prepared via an improved liquid deposition method. New J. Chem. 2009, 33, 1673-1679. [CrossRef]

209. Wenderich, K.; Mul, G. Methods, mechanism, and applications of photodeposition in photocatalysis: A review. Chem. Rev. 2016, 116, 14587-14619. [CrossRef] [PubMed]

210. Yen, C.F.; Lee, I.H.; Chang, S.H.; Lin, C.T. The effect of annealing temperature of titanium oxide film for photocatalytic activity by liquid phase deposition. In Proceedings of the 2017 International Conference on Applied System Innovation (ICASI), Sapporo, Japan, 13-17 May 2017; pp. 664-667.

211. Zhou, L.; Zhao, W.; Fang, Y. Photocatalytic Activity of Anatase $\mathrm{TiO}_{2}$ Thin Films Prepared by Liquid Phase Deposition. Chin. J. Chem 2002, 19, 919-922.

212. Wang, L.; Wan, Y.; Li, Y.; Cai, Z.; Li, H.L.; Zhao, X.S.; Li, Q. Binary colloidal crystals fabricated with a horizontal deposition method. Langmuir 2009, 25, 6753-6759. [CrossRef]

213. Abou-Helal, M.O.; Seeber, W.T. Preparation of $\mathrm{TiO}_{2}$ thin films by spray pyrolysis to be used as a photocatalyst. Appl. Surf. Sci. 2002, 195, 53-62. [CrossRef]

214. Yuan, $\mathrm{C}$. Low-temperature preparation of photocatalytic $\mathrm{TiO}_{2}$ thin films on polymer substrates by direct deposition from anatase sol. Mater. Sci. Technol. 2006, 22, 239-244.

215. Kawai, T.; Sakata, T. Photocatalytic hydrogen production from liquid methanol and water. J. Chem. Soc. Chem. Commun. 1980, 15, 694-695. [CrossRef]

216. Elvington, M.; Brown, J.; Arachchige, S.M.; Brewer, K.J. Photocatalytic hydrogen production from water employing a $\mathrm{Ru}, \mathrm{Rh}, \mathrm{Ru}$ molecular device for photoinitiated electron collection. J. Am. Chem. Soc. 2007, 129, 10644-10645. [CrossRef] [PubMed]

217. Almazroai, L.S. Photocatalytic hydrogen production. Chem. Commun. 2009, 47, 9268-9274.

218. Amirav, L.; Alivisatos, A.P. Photocatalytic hydrogen production with tunable nanorod heterostructures. J. Phys. Chem. Lett. 2010, 1, 1051-1054. [CrossRef]

219. Murdoch, M.; Waterhouse, G.I.N.; Nadeem, M.A.; Metson, J.B.; Keane, M.A.; Howe, R.F.; Llorca, J.; Idriss, H. The effect of gold loading and particle size on photocatalytic hydrogen production from ethanol over $\mathrm{Au} / \mathrm{TiO}{ }_{2}$ nanoparticles. Nat. Chem. 2011, 3, 489-492. [CrossRef]

220. TS, T.; DG, N. Photocatalytic hydrogen production. Chem. Commun. 2011, 47, 9268-9274.

221. Xu, W.P.; Zheng, L.; Xin, H.; Lin, C.; Okuyama, M. Formation of $\mathrm{BaTiO}_{3}$ and $\mathrm{PbTiO}_{3}$ thin films under mild hydrothermal conditions. J. Mater. Res. 1996, 11, 821-824. [CrossRef]

222. Spanhel, L.; Weller, H.; Henglein, A. Photochemistry of semiconductor colloids. 22. Electron ejection from illuminated cadmium sulfide into attached titanium and zinc oxide particles. J. Am. Chem. Soc. 1987, 109, 1-6. [CrossRef]

223. Guidi, V.; Carotta, M.C.; Ferroni, M.; Martinelli, G.; Sacerdoti, M. Effect of dopants on grain coalescence and oxygen mobility in nanostructured titania anatase and rutile. J. Phys. Chem. B 2003, 107, 120-124. [CrossRef]

224. Yin, J.; Zou, Z.; Ye, J. Photophysical and photocatalytic properties of $\mathrm{MIn}_{0.5} \mathrm{Nb}_{0.5} \mathrm{O}_{3}(\mathrm{M}=\mathrm{Ca}, \mathrm{Sr}$, and $\mathrm{Ba})$. J. Phys. Chem. B 2003, 34, 14265-14269.

225. Jaffrezicrenault, N.; Pichat, P.; Foissy, A.; Mercier, R. Effect of deposited Pt particles on the surface charge of $\mathrm{TiO}_{2}$ aqueous suspensions by potentiometry, electrophoresis, and labeled ion adsorption. J. Phys. Chem. 1986, 12, 2733-2738. [CrossRef] 
226. Fu, X.; Zeltner, W.A.; Anderson, M.A. The gas-phase photocatalytic mineralization of benzene on porous titania-based catalysts. Appl. Catal. B Environ. 1995, 6, 209-224. [CrossRef]

227. Li, C.H.; Hsieh, Y.H.; Chiu, W.T.; Liu, C.C.; Kao, C.L. Study on preparation and photocatalytic performance of $\mathrm{Ag} / \mathrm{TiO}_{2}$ and $\mathrm{Pt} / \mathrm{TiO}_{2}$ photocatalysts. Sep. Purif. Technol. 2007, 58, 148-151. [CrossRef]

228. Ou, H.H.; Lo, S.L. Effect of Pt/Pd-doped $\mathrm{TiO}_{2}$ on the photocatalytic degradation of trichloroethylene. J. Mol. Catal. A Chem. 2007, 275, 200-205. [CrossRef]

229. Chavadej, S.; Phuaphromyod, P.; Gulari, E.; Rangsunvigit, P.; Sreethawong, T. Photocatalytic degradation of 2-propanol by using $\mathrm{Pt} / \mathrm{TiO}_{2}$ prepared by microemulsion technique. Chem. Eng. J. 2008, 137, 489-495. [CrossRef]

230. Ma, Y.S.; Chang, C.N.; Chiang, Y.P.; Sung, H.F.; Chao, A.C. Photocatalytic degradation of lignin using Pt/TiO 2 as the catalyst. Chemosphere 2008, 71, 998-1004. [CrossRef]

231. Yu, Z.; Chuang, S.S.C. The effect of pt on the photocatalytic degradation pathway of methylene blue over $\mathrm{TiO}_{2}$ under ambient conditions. Appl. Catal. B Environ. 2008, 83, 277-285. [CrossRef]

232. Liang, Y.; Ding, M.; Yang, Y.; Xu, K.; Luo, X.; Yu, T.; Zhang, W.; Liu, W.; Yuan, C. Highly dispersed pt nanoparticles on hierarchical titania nanoflowers with $\{010\}$ facets for gas sensing and photocatalysis. J. Mater. Sci. 2019, 54, 6826-6840. [CrossRef]

233. Rengaraj, S.; Li, X.Z. Enhanced photocatalytic activity of $\mathrm{TiO}_{2}$ by doping with ag for degradation of 2,4,6-trichlorophenol in aqueous suspension. J. Mol. Catal. A Chem. 2006, 243, 60-67. [CrossRef]

234. Panpranot, J.; Nakkararuang, L.; Ngamsom, B.; Praserthdam, P. Synthesis, characterization, and catalytic properties of pd and $\mathrm{Pd}-\mathrm{Ag}$ catalysts supported on nanocrystalline $\mathrm{TiO}_{2}$ prepared by the solvothermal method. Catal. Lett. 2005, 103, 53-58. [CrossRef]

235. Xin, B.; Jing, L.; Ren, Z.; Wang, B.; Fu, H. Effects of simultaneously doped and deposited Ag on the photocatalytic activity and surface states of $\mathrm{TiO}_{2}$. J. Phys. Chem. B 2005, 109, 2805-2809. [CrossRef] [PubMed]

236. Zhang, F.; Jin, R.; Chen, J.; Shao, C.; Gao, W.; Li, L.; Guan, N. High photocatalytic activity and selectivity for nitrogen in nitrate reduction on $\mathrm{Ag} / \mathrm{TiO}_{2}$ catalyst with fine silver clusters. J. Catal. 2005, 232, 424-431. [CrossRef]

237. Anandan, S.; Kumar, P.S.; Pugazhenthiran, N.; Madhavan, J.; Maruthamuthu, P. Effect of loaded silver nanoparticles on $\mathrm{TiO}_{2}$ for photocatalytic degradation of acid red 88. Sol. Energy Mater. Sol. C 2008, 92, 929-937. [CrossRef]

238. Sobana, N.; Selvam, K.; Swaminathan, M. Optimization of photocatalytic degradation conditions of direct red 23 using nano-Ag doped $\mathrm{TiO}_{2}$. Sep. Purif. Technol. 2008, 62, 648-653. [CrossRef]

239. Ranjit, K.T.; Varadarajan, T.K.; Viswanathan, B. Photocatalytic reduction of nitrite and nitrate ions to ammonia on $\mathrm{Ru} / \mathrm{TiO}_{2}$ catalysts. J. Photochem. Photobiol. A 1995, 89, 67-68. [CrossRef]

240. Chu, S.Z.; Inoue, S.; Wada, K.; Li, D.; Suzuki, J. Fabrication and photocatalytic characterizations of ordered nanoporous $\mathrm{x}$-doped $(\mathrm{x}=\mathrm{N}, \mathrm{C}, \mathrm{S}, \mathrm{Ru}, \mathrm{Te}$, and $\mathrm{Si}) \mathrm{TiO}_{2} / \mathrm{Al}_{2} \mathrm{O}_{3}$ films on ITO/glass. Langmuir ACS J. Surf. Colloids 2005, 21, 8035-8041. [CrossRef] [PubMed]

241. Arana, J.; Dona-Rodrıguez, J.M.; González-Dıaz, O.; Rendón, E.T.; Melián, J.H.; Colon, G.; Nav10, J.A.; Peña, J.P. Gas-phase ethanol photocatalytic degradation study with $\mathrm{TiO}_{2}$ doped with $\mathrm{Fe}, \mathrm{Pd}$ and $\mathrm{Cu}$. J. Mol. Catal. A Chem. 2004, 215, 153-160. [CrossRef]

242. Araña, J.; Doña-Rodríguez, J.M.; Melián, J.A.H.; Rendón, E.T.; Díaz, O.G. Role of Pd and Cu in gas-phase alcohols photocatalytic degradation with doped $\mathrm{TiO}_{2}$. J. Photochem. Photobiol. A 2005, 174, 7-14. [CrossRef]

243. Erkan, A.; Bakir, U.; Karakas, G. Photocatalytic microbial inactivation over pd doped $\mathrm{SnO}_{2}$ and $\mathrm{TiO}_{2}$ thin films. J. Photochem. Photobiol. A 2006, 184, 313-321. [CrossRef]

244. Aramendía, M.A.; Borau, V.; Colmenares, J.C.; Marinas, A.; Marinas, J.M.; Navío, J.A.; Urbano, F.J. Modification of the photocatalytic activity of $\mathrm{Pd} / \mathrm{TiO}_{2}$ and $\mathrm{Zn} / \mathrm{TiO}_{2}$ systems through different oxidative and reductive calcination treatments. Appl. Catal. B Environ. 2008, 80, 88-97. [CrossRef]

245. Zhu, B.; Li, K.; Zhou, J.; Wang, S.; Zhang, S.; Wu, S.; Huang, W. The preparation of palladium-modified $\mathrm{TiO}_{2}$ nanofibers and their photocatalytic performance. Catal. Commun. 2008, 9, 2323-2326. [CrossRef]

246. Arabatzis, I.M.; Stergiopoulos, T.; Andreeva, D.; Kitova, S.; Neophytides, S.G.; Falaras, P. Characterization and photocatalytic activity of $\mathrm{Au} / \mathrm{TiO}_{2}$ thin films for azo-dye degradation. J. Catal. 2003, 220, 127-135. [CrossRef]

247. Chiarello, G.L.; Selli, E.; Forni, L. Photocatalytic hydrogen production over flame spray pyrolysis-synthesised $\mathrm{TiO}_{2}$ and $\mathrm{Au} / \mathrm{TiO}_{2}$. Appl. Catal. B Environ. 2008, 84, 332-339. [CrossRef] 
248. Jung, J.M.; Wang, M.; Kim, E.J.; Park, C.; Hahn, S.H. Enhanced photocatalytic activity of Au-buffered $\mathrm{TiO}_{2}$ thin films prepared by radio frequency magnetron sputtering. Appl. Catal. B Environ. 2008, 84, 389-392. [CrossRef]

249. Kumar, P.S.S.; Sivakumar, R.; Anandan, S.; Madhavan, J.; Maruthamuthu, P.; Ashokkumar, M. Photocatalytic degradation of acid red 88 using $\mathrm{Au}-\mathrm{TiO}_{2}$ nanoparticles in aqueous solutions. Water Res. 2008, 42, 4878-4884. [CrossRef] [PubMed]

250. Yogi, C.; Kojima, K.; Wada, N.; Tokumoto, H.; Takai, T.; Mizoguchi, T.; Tamiaki, H. Photocatalytic degradation of methylene blue by $\mathrm{TiO}_{2}$ film and au particles- $\mathrm{TiO}_{2}$ composite film. Thin Solid Film 2008, 516, 5881-5884. [CrossRef]

251. Subramanian, V.; Wolf, E.E.; Kamat, P.V. Influence of metal/metal ion concentration on the photocatalytic activity of $\mathrm{TiO}_{2}-\mathrm{Au}$ composite nanoparticles. Langmuir 2003, 19, 469-474. [CrossRef]

252. Kang, M.G.; Han, H.E.; Kim, K.J. Enhanced photodecomposition of 4-chlorophenol in aqueous solution by deposition of CdS on $\mathrm{TiO}_{2}$. J. Photochem. Photobiol. A 1999, 125, 119-125. [CrossRef]

253. Wilke, K.; Breuer, H.D. The influence of transition metal doping on the physical and photocatalytic properties of titania. J. Photochem. Photobiol. A 1999, 121, 49-53. [CrossRef]

254. Dhananjeyan, M.R.; Kandavelu, V.; Renganathan, R. A study on the photocatalytic reactions of $\mathrm{TiO}_{2}$ with certain pyrimidine bases: Effects of dopants $\left(\mathrm{Fe}^{3+}\right)$ and calcination. J. Mol. Catal. A Chem. 2000, 151, 217-223. [CrossRef]

255. Hwang, S.; Lee, M.C.; Choi, W. Highly enhanced photocatalytic oxidation of Co on titania deposited with pt nanoparticles: Kinetics and mechanism. Appl. Catal. B Environ. 2003, 46, 49-63. [CrossRef]

256. Wang, Z.S.; Ebina, Y.; Takada, K.; Mamoru Watanabe, A.; Sasaki, T. Inorganic multilayer assembly of titania semiconductor nanosheets and Ru complexes. Langmuir 2003, 19, 9534-9537. [CrossRef]

257. Naoi, K.; Yoshihisa Ohko, A.; Tatsuma, $\mathrm{T}$. $\mathrm{TiO}_{2}$ films loaded with silver nanoparticles: Control of multicolor photochromic behavior. J. Am. Chem. Soc. 2004, 126, 3664-3668. [CrossRef]

258. Wang, C.Y.; Liu, C.Y.; Chen, J.; Shen, T. The surface chemistry of hybrid nanometer-sized particlesii. Characterization and microstructure of au clusters supported on $\mathrm{TiO}_{2}$. J. Colloid Interface Sci. 1997, 191, 464-470. [CrossRef] [PubMed]

259. Zhang, Z.B.; Wang, C.C.; Rama Zakaria, A. Role of particle size in nanocrystalline $\mathrm{TiO}_{2}$-based photocatalysts. J. Phys. Chem. B 1998, 102, 10871-10878. [CrossRef]

260. Sato, S.; White, J.M. Photodecomposition of water over $\mathrm{Pt} / \mathrm{TiO}_{2}$ catalysts. Chem. Phys. Lett. 1980, 72, 83-86. [CrossRef]

261. Martra, G. Lewis acid and base sites at the surface of microcrystalline $\mathrm{TiO}_{2}$ anatase: Relationships between surface morphology and chemical behaviour. Appl. Catal. A Gen. 2000, 200, 275-285. [CrossRef]

262. Kotolevich, Y.; Kolobova, E.; Mamontov, G.; Khramov, E.; Ortega, J.E.C.; Tiznado, H.; Farías, M.H.; Bogdanchikova, N.; Zubavichus, Y.; Mota-Morales, J.D. Au/ $/ \mathrm{TiO}_{2}$ catalysts promoted with $\mathrm{Fe}$ and $\mathrm{Mg}$ for n-octanol oxidation under mild conditions. Catal. Today 2016, 278, 104-112. [CrossRef]

263. Klein, M.; Nadolna, J.; Gołabiewska, A.; Mazierski, P.; Klimczuk, T.; Remita, H.; Zaleska-Medynska, A. The effect of metal cluster deposition route on structure and photocatalytic activity of mono- and bimetallic nanoparticles supported on $\mathrm{TiO}_{2}$ by radiolytic method. Appl. Surf. Sci. 2016, 378, 37-48. [CrossRef]

264. Zhang, D.; Wang, J. Uv-visible light-activated Au@ pre-sulphated, monodisperse $\mathrm{TiO}_{2}$ aggregates for treatment of congo red and phthalylsulfathiazole. J. Water Process Eng. 2015, 7, 187-195. [CrossRef]

265. Padilla, R.H.; Priecel, P.; Lin, M.; Lopezsanchez, J.A.; Zhong, Z. A versatile sonication-assisted deposition-reduction method for preparing supported metal catalysts for catalytic applications. Ultrason. Sonochem. 2016, 35, 631-639. [CrossRef] [PubMed]

266. Jaafar, N.F.; Jalil, A.A.; Triwahyono, S.; Efendi, J.; Mukti, R.R.; Jusoh, R.; Jusoh, N.W.C.; Karim, A.H.; Salleh, N.F.M.; Suendo, V. Direct in situ activation of $\mathrm{Ag}^{0}$ nanoparticles in synthesis of $\mathrm{Ag} / \mathrm{TiO}_{2}$ and its photoactivity. Appl. Surf. Sci. 2015, 338, 75-84. [CrossRef]

267. Arabzadeh, A.; Salimi, A. One dimensional CdS nanowire@ $\mathrm{TiO}_{2}$ nanoparticles core-shell as high performance photocatalyst for fast degradation of dye pollutants under visible and sunlight irradiation. J. Colloid Interface Sci. 2016, 479, 43-54. [CrossRef]

268. Wu, G.; Li, J.; Fang, Z.; Lan, L.; Wang, R.; Gong, M.; Chen, Y. $\mathrm{FeVO}_{4}$ nanorods supported $\mathrm{TiO}_{2}$ as a superior catalyst for $\mathrm{NH}_{3}-\mathrm{SCR}$ reaction in a broad temperature range. Catal. Commun. 2015, 64, 75-79. [CrossRef] 
269. Chu, H.; Lei, W.; Liu, X.; Li, J.; Zheng, W.; Zhu, G.; Li, C.; Pan, L.; Sun, C. Synergetic effect of TiO ${ }_{2}$ as co-catalyst for enhanced visible light photocatalytic reduction of $\mathrm{Cr}(\mathrm{vi})$ on $\mathrm{MoSe}_{2}$. Appl. Catal. A Gen. 2016, 521, 19-25. [CrossRef]

270. Das, L.; Basu, J.K. Photocatalytic treatment of textile effluent using titania-zirconia nano composite catalyst. J. Ind. Eng. Chem. 2015, 24, 245-250. [CrossRef]

271. Shen, J.; Yang, H.; Feng, Y.; Cai, Q.; Shen, Q. Synthesis of 3D hierarchical porous $\mathrm{TiO}_{2} / \mathrm{InVO}_{4}$ nanocomposites with enhanced visible-light photocatalytic properties. Solid State Sci. 2014, 32, 8-12. [CrossRef]

272. Shen, J.; Yang, H.; Shen, Q.; Feng, Y.; Cai, Q. Template-free preparation and properties of mesoporous g- $\mathrm{C}_{3} \mathrm{~N}_{4} / \mathrm{TiO}_{2}$ nanocomposite photocatalyst. CrystEngComm 2014, 16, 1868-1872. [CrossRef]

273. Gao, H.; Wang, H.; Jin, Y.; Lv, J.; Xu, G.; Wang, D.; Zhang, X.; Chen, Z.; Zheng, Z.; Wu, Y. Controllable fabrication of immobilized ternary $\mathrm{CdS} / \mathrm{Pt}-\mathrm{TiO}_{2}$ heteronanostructures toward high-performance visible-light driven photocatalysis. Phys. Chem. Chem. Phys. 2015, 17, 17755-17761. [CrossRef]

274. Hui, F.; Niu, T.; Zhang, S.; Bo, L.; Cai, Q. Fabrication of layered (CdS-Mn/MoS $/$ CdTe)-promoted $\mathrm{TiO}_{2}$ nanotube arrays with superior photocatalytic properties. J. Colloid Interface Sci. 2017, 486, 58-66.

275. Borgarello, E.; Kiwi, J.; Graetzel, M.; Pelizzetti, E.; Visca, M. Visible light induced water cleavage in colloidal solutions of chromium-doped titanium dioxide particles. J. Am. Chem. Soc. 1982, 104, 2996-3002. [CrossRef]

276. Choi, W.; Termin, A.; Hoffmann, M.R. The role of metal ion dopants in quantum-sized $\mathrm{TiO}_{2}$ : Correlation between photoreactivity and charge carrier recombination dynamics. J. Phys. Chem. 1994, 98, 13669-13679. [CrossRef]

277. Wang, Q.; Jin, R.; Zhang, M.; Gao, S. Solvothermal preparation of Fe-doped $\mathrm{TiO}_{2}$ nanotube arrays for enhancement in visible light induced photoelectrochemical performance. J. Alloys Compd. 2017, 690, 139-144. [CrossRef]

278. Inturi, S.N.R.; Suidan, M.; Smirniotis, P.G. Influence of synthesis method on leaching of the Cr- $\mathrm{TiO}_{2}$ catalyst for visible light liquid phase photocatalysis and their stability. Br. Med. J. 2016, 180, 351-361. [CrossRef]

279. Ma, C.; Wang, F.; Zhang, C.; Yu, Z.; Wei, J.; Yang, Z.; Li, Y.; Li, Z.; Zhu, M.; Shen, L. Photocatalytic decomposition of congo red under visible light irradiation using $\mathrm{MgZnCr}-\mathrm{TiO}_{2}$ layered double hydroxide. Chemosphere 2017, 168, 80-90. [CrossRef] [PubMed]

280. Villabona-Leal, E.G.; López-Neira, J.P.; Pedraza-Avella, J.A.; Pérez, E.; Meza, O. Screening of factors influencing the photocatalytic activity of $\mathrm{TiO}_{2}: \mathrm{Ln}(\mathrm{Ln}=\mathrm{La}, \mathrm{Ce}, \mathrm{Pr}, \mathrm{Nd}, \mathrm{Sm}, \mathrm{Eu}$ and $\mathrm{Gd})$ in the degradation of dyes. Comp. Mater. Sci. 2015, 107, 48-53. [CrossRef]

281. Malengreaux, C.M.; Pirard, S.L.; Léonard, G.; Mahy, J.G.; Herlitschke, M.; Klobes, B.; Hermann, R.; Heinrichs, B.; Bartlett, J.R. Study of the photocatalytic activity of $\mathrm{Fe}^{3+}, \mathrm{Cr}^{3+}, \mathrm{La}^{3+}$ and $\mathrm{Eu}^{3+}$ single-doped and co-doped $\mathrm{TiO}_{2}$ catalysts produced by aqueous sol-gel processing. J. Alloys Compd. 2017, 691, 726-738. [CrossRef]

282. Zang, L.; Macyk, W.; Lange, C.; Maier, W.F.; Antonius, C.; Meissner, D.; Kisch, H. Visible-light detoxification and charge generation by transition metal chloride modified Titania. Chemistry 2000, 6, 379-384. [CrossRef]

283. Mittal, A.; Mari, B.; Sharma, S.; Kumari, V.; Maken, S.; Kumari, K.; Kumar, N. Non-metal modified TiO ${ }_{2}$ : A step towards visible light photocatalysis. J. Mater. Sci. Mater. Electron. 2019, 30, 3186-3207. [CrossRef]

284. Dolat, D.; Quici, N.; Kusiak-Nejman, E.; Morawski, A.; Puma, G.L. One-step, hydrothermal synthesis of nitrogen, carbon co-doped titanium dioxide $\left(\mathrm{N}, \mathrm{C}-\mathrm{TiO}_{2}\right)$ photocatalysts. Effect of alcohol degree and chain length as carbon dopant precursors on photocatalytic activity and catalyst deactivation. Appl. Catal. B Environ. 2012, 115, 81-89. [CrossRef]

285. Asahi, R.; Morikawa, T.; Ohwaki, T.; Aoki, K.; Taga, Y. Visible-light photocatalysis in nitrogen-doped titanium oxides. Science 2001, 293, 269-271. [CrossRef] [PubMed]

286. Kitano, M.; Funatsu, K.; Matsuoka, M.; Ueshima, M.; Anpo, M. Preparation of nitrogen-substituted $\mathrm{TiO}_{2}$ thin film photocatalysts by the radio frequency magnetron sputtering deposition method and their photocatalytic reactivity under visible light irradiation. J. Phys. Chem. B 2006, 110, 25266-25272. [CrossRef] [PubMed]

287. Horovitz, I.; Avisar, D.; Baker, M.A.; Grilli, R.; Lozzi, L.; Di, C.D.; Mamane, H. Carbamazepine degradation using a $\mathrm{N}$-doped $\mathrm{TiO}_{2}$ coated photocatalytic membrane reactor: Influence of physical parameters. J. Hazard. Mater. 2016, 310, 98-107. [CrossRef]

288. Lei, Z.; Zhao, L.; Li, M.; Jin, Y.; Song, W.; Zeng, D.; Xie, C. A modular calcination method to prepare modified $\mathrm{N}$-doped $\mathrm{TiO}_{2}$ nanoparticle with high photocatalytic activity. Appl. Catal. B Environ. 2016, 183, 308-316. 
289. Gong, Y.; Zhao, X.; Zhang, H.; Yang, B.; Xiao, K.; Guo, T.; Zhang, J.; Shao, H.; Wang, Y.; Yu, G. MOF-derived nitrogen doped carbon modified $\mathrm{g}-\mathrm{C}_{3} \mathrm{~N}_{4}$ heterostructure composite with enhanced photocatalytic activity for bisphenol a degradation with peroxymonosulfate under visible light irradiation. Appl. Catal. B Environ. 2018, 233, 35-45. [CrossRef]

290. Castellanosleal, E.L.; Acevedopeña, P.; Güizaargüello, V.R.; Córdobatuta, E.M.; Castellanosleal, E.L.; Acevedopeña, P.; Güizaargüello, V.R.; Córdobatuta, E.M. $\mathrm{N}$ and $\mathrm{f}$ codoped $\mathrm{TiO}_{2}$ thin films on stainless steel for photoelectrocatalytic removal of cyanide ions in aqueous solutions. Mater. Res. 2017, 20, 487-495. [CrossRef]

291. Khan, S.U.; Al-Shahry, M.; Ingler, W.B. Efficient photochemical water splitting by a chemically modified n- $\mathrm{TiO}_{2}$. Science 2002, 297, 2243-2245. [CrossRef]

292. Tachikawa, T.; Tojo, S.; Kawai, K.; Endo, M.; Fujitsuka, M.; Ohno, T.; Nishijima, K.; Miyamoto, Z.; Majima, T. Photocatalytic oxidation reactivity of holes in the sulfur- and carbon-doped $\mathrm{TiO}_{2}$ powders studied by time-resolved diffuse reflectance spectroscopy. J. Phys. Chem. B 2004, 108, 19299-19306. [CrossRef]

293. Valentin, C.D.; Pacchioni, G.; Selloni, A. Theory of carbon doping of titanium dioxide. Chem. Mater. 2005, 17, 6656-6665. [CrossRef]

294. Ohno, T.; Akiyoshi, M.; Umebayashi, T.; Asai, K.; Mitsui, T.; Matsumura, M. Preparation of S-doped $\mathrm{TiO}_{2}$ photocatalysts and their photocatalytic activities under visible light. Appl. Catal. A Gen. 2004, 265, 115-121. [CrossRef]

295. Li, H.; Zhang, X.; Huo, Y.; Zhu, J. Supercritical preparation of a highly active S-doped $\mathrm{TiO}_{2}$ photocatalyst for methylene blue mineralization. Environ. Sci. Technol. 2007, 41, 4410-4414. [CrossRef] [PubMed]

296. Nishijima, K.; Ohtani, B.; Yan, X.; Kamai, T.A.; Chiyoya, T.; Tsubota, T.; Murakami, N.; Ohno, T. Incident light dependence for photocatalytic degradation of acetaldehyde and acetic acid on S-doped and N-doped $\mathrm{TiO}_{2}$ photocatalysts. Chem. Phys. 2007, 339, 64-72. [CrossRef]

297. Yang, K.; Dai, Y.; Huang, B. Understanding photocatalytic activity of S- and P-doped $\mathrm{TiO}_{2}$ under visible light from first-principles. J. Phys. Chem. C 2007, 111, 18985-18994. [CrossRef]

298. Ogle, C.K.; Trocki, O.; Nagy, H.; Ogle, J.D.; Warden, G.D.; Alexander, J.W. Development of metal cation compound-loaded S-doped $\mathrm{TiO}_{2}$ photocatalysts having a rutile phase under visible light. Appl. Catal. A Gen. 2008, 349, 70-75.

299. Wang, Y.; Li, J.; Peng, P.; Lu, T.; Wang, L. Preparation of S-TiO 2 photocatalyst and photodegradation of l-acid under visible light. Appl. Surf. Sci. 2008, 254, 5276-5280. [CrossRef]

300. Shi, Q.; Yang, D.; Jiang, Z.; Li, J. Visible-light photocatalytic regeneration of nadh using P-doped $\mathrm{TiO}_{2}$ nanoparticles. J. Mol. Catal. B Enzym. 2006, 43, 44-48. [CrossRef]

301. Yu, H.F. Photocatalytic abilities of gel-derived P-doped $\mathrm{TiO}_{2}$. J. Phys. Chem. Solids 2007, 68, 600-607. [CrossRef]

302. Wu, G.; Chen, A. Direct growth of F-doped $\mathrm{TiO}_{2}$ particulate thin films with high photocatalytic activity for environmental applications. J. Photochem. Photobiol. A 2008, 195, 47-53. [CrossRef]

303. Yu, J.C.; Yu, J.; Ho, W.; Jiang, Z.; Zhang, L. Effects of F-doping on the photocatalytic activity and microstructures of nanocrystalline $\mathrm{TiO}_{2}$ powders. Chem. Mater. 2002, 14, 3808-3816. [CrossRef]

304. Park, J.S.; Choi, W. Enhanced remote photocatalytic oxidation on surface-fluorinated $\mathrm{TiO}_{2}$. Langmuir ACS J. Surf. Colloids 2004, 20, 11523-11527. [CrossRef] [PubMed]

305. Xie, Y.; Zhao, X.; Li, Y.; Zhao, Q.; Zhou, X.; Yuan, Q. Ctab-assisted synthesis of mesoporous F-N-codoped $\mathrm{TiO}_{2}$ powders with high visible-light-driven catalytic activity and adsorption capacity. J. Solid. State. Chem. 2008, 181, 1936-1942. [CrossRef]

306. Xu, J.; Ao, Y.; Fu, D.; Yuan, C. Low-temperature preparation of F-doped $\mathrm{TiO}_{2}$ film and its photocatalytic activity under solar light. Appl. Surf. Sci. 2008, 254, 3033-3038. [CrossRef]

307. Song, C.L.; Wang, J.; Zeng, M.L.; Zhu, J.Q.; Liu, Y.; Xu, G.; Han, G.R. Investigation of photocatalytic and low-emissivity properties of $\mathrm{TiO}_{2}$ : F films featuring columnar structure prepared on $\mathrm{SnO}_{2}$ : $\mathrm{F}$ substrate by sol-gel method. J. Sol-Gel Sci. Technol. 2013, 68, 121-127. [CrossRef]

308. Yamazaki, S.; Yoshida, A.; Abe, H. Photocatalytic degradation of chloroform in the gas phase on the porous $\mathrm{TiO}_{2}$ pellets: Effect of cl accumulated on the catalyst surface. J. Photochem. Photobiol. A 2005, 169, 191-196. [CrossRef]

309. Hong, X.; Wang, Z.; Cai, W.; Lu, F.; Zhang, J.; Yang, Y.; Ma, N.; Liu, Y. Visible-light-activated nanoparticle photocatalyst of iodine-doped titanium dioxide. Chem. Mater. 2005, 17, 1548-1552. [CrossRef] 
310. Moon, S.C.; Mametsuka, H.; Tabata, S.; Suzuki, E. Photocatalytic production of hydrogen from water using $\mathrm{TiO}_{2}$ and $\mathrm{B} / \mathrm{TiO}_{2}$. Catal. Today 2000, 58, 125-132. [CrossRef]

311. Zhao, W.; Ma, W.; Chen, C.; Zhao, J.; Shuai, Z. Efficient degradation of toxic organic pollutants with $\mathrm{Ni}_{2} \mathrm{O}_{3} / \mathrm{TiO}_{(2-\mathrm{x})}$ Bx under visible irradiation. J. Am. Chem. Soc. 2004, 126, 4782-4783. [CrossRef] [PubMed]

312. Fittipaldi, M.; Gombac, V.; Montini, T.; Fornasiero, P.; Graziani, M. A high-frequency (95 GHz) electron paramagnetic resonance study of B-doped $\mathrm{TiO}_{2}$ photocatalysts. Inorg. Chim. Acta 2008, 361, 3980-3987. [CrossRef]

313. Li, J.S.; Shieh, D.L.; Li, D.Y.; Ho, C.H.; Yang, S.J.; Lin, J.L. Photodegradation of $\mathrm{CH}_{3} \mathrm{I}$ on mesoporous $\mathrm{TiO}_{2}-\mathrm{B}$ nanofibers with Au nanoparticles. Appl. Surf. Sci. 2008, 254, 4655-4664. [CrossRef]

314. Takabayashi, S.; Nakamura, R.; Nakato, Y. A nano-modified $\mathrm{Si} / \mathrm{TiO}_{2}$ composite electrode for efficient solar water splitting. J. Photochem. Photobiol. A 2004, 166, 107-113. [CrossRef]

315. Yang, K.; Dai, Y.; Huang, B. First-principles calculations for geometrical structures and electronic properties of Si-doped $\mathrm{TiO}_{2}$. Chem. Phys. Lett. 2008, 456, 71-75. [CrossRef]

316. Jin, R.; Wu, Z.; Liu, Y.; Jiang, B.; Wang, H. Photocatalytic reduction of no with $\mathrm{NH}_{3}$ using Si-doped $\mathrm{TiO}_{2}$ prepared by hydrothermal method. J. Hazard. Mater. 2009, 161, 42-48. [CrossRef] [PubMed]

317. Simsek, E.B. Solvothermal synthesized boron doped $\mathrm{TiO}_{2}$ catalysts: Photocatalytic degradation of endocrine disrupting compounds and pharmaceuticals under visible light irradiation. Appl. Catal. B Environ. 2017, 200, 309-322. [CrossRef]

318. He, D.; Li, Y.; Wang, I.; Wu, J.; Yang, Y.; An, Q. Carbon wrapped and doped $\mathrm{TiO}_{2}$ mesoporous nanostructure with efficient visible-light photocatalysis for NO removal. Appl. Surf. Sci. 2017, 391, 318-325. [CrossRef]

319. El-Sheikh, S.M.; Khedr, T.M.; Hakki, A.; Ismail, A.A.; Badawy, W.A.; Bahnemann, D.W. Visible light activated carbon and nitrogen co-doped mesoporous $\mathrm{TiO}_{2}$ as efficient photocatalyst for degradation of ibuprofen. Sep. Purif. Technol. 2017, 173, 258-268. [CrossRef]

320. Zhang, Y.; Li, L.; Liu, H.; Lu, T. Graphene oxide and f co-doped $\mathrm{TiO}_{2}$ with (001) facets for the photocatalytic reduction of bromate: Synthesis, characterization and reactivity. Chem. Eng. J. 2017, 307, 860-867. [CrossRef]

321. Lei, X.F.; Zhang, Z.N.; Wu, Z.X.; Piao, Y.J.; Chen, C.; Li, X.; Xue, X.X.; Yang, H. Synthesis and characterization of $\mathrm{Fe}, \mathrm{N}$ and $\mathrm{C}$ tri-doped polymorphic $\mathrm{TiO}_{2}$ and the visible light photocatalytic reduction of cr(vi). Sep. Purif. Technol. 2017, 174, 66-74. [CrossRef]

322. Chen, Y.; Liu, K. Fabrication of $\mathrm{Ce} / \mathrm{N}$ co-doped $\mathrm{TiO}_{2} /$ diatomite granule catalyst and its improved visible-light-driven photoactivity. J. Hazard. Mater. 2017, 324, 139-150. [CrossRef]

323. Han, Y.; Zhang, J.; Zhao, Y. Visible-light-induced photocatalytic oxidation of nitric oxide and sulfur dioxide: Discrete kinetics and mechanism. Energy 2016, 103, 725-734. [CrossRef]

324. Wan, J.; Wei, M.; Hu, Z.; Peng, Z.; Wang, B.; Feng, D.; Shen, Y. Ternary composites of $\mathrm{TiO}_{2}$ nanotubes with reduced graphene oxide (rGO) and meso-tetra (4-carboxyphenyl) porphyrin for enhanced visible light photocatalysis. Int. J. Hydrogen Energy 2016, 41, 14692-14703. [CrossRef]

325. Zoltan, T.; Rosales, M.C.; Yadarola, C. Reactive oxygen species quantification and their correlation with the photocatalytic activity of $\mathrm{TiO}_{2}$ (anatase and rutile) sensitized with asymmetric porphyrins. J. Environ. Chem. Eng. 2016, 4, 3967-3980. [CrossRef]

326. Zhao, X.; Liu, X.; Yu, M.; Wang, C.; Li, J. The highly efficient and stable Cu, Co, Zn-porphyrin-TiO 2 photocatalysts with heterojunction by using fashioned one-step method. Dyes Pigments 2017, 136, 648-656. [CrossRef]

327. Wei, M.; Wan, J.; Hu, Z.; Peng, Z.; Wang, B. Enhanced photocatalytic degradation activity over $\mathrm{TiO}_{2}$ nanotubes co-sensitized by reduced graphene oxide and copper(ii) meso-tetra(4-carboxyphenyl) porphyrin. Appl. Surf. Sci. 2016, 377, 149-158. [CrossRef]

328. Chowdhury, P.; Athapaththu, S.; Elkamel, A.; Ray, A.K. Visible-solar-light-driven photo-reduction and removal of cadmium ion with eosin Y-sensitized $\mathrm{TiO}_{2}$ in aqueous solution of triethanolamine. Sep. Purif. Technol. 2017, 174, 109-115. [CrossRef]

329. Altın, İ.; Sökmen, M.; Bıyıklığlu, Z. Sol gel synthesis of cobalt doped $\mathrm{TiO}_{2}$ and its dye sensitization for efficient pollutant removal. Mater. Sci. Semicond. Proc. 2016, 45, 36-44. [CrossRef]

330. Albay, C.; Koç, M.; Altın, İ.; Bayrak, R.; Değirmencioğlu, İ.; Sökmen, M. New dye sensitized photocatalysts: Copper(ii)-phthalocyanine/ $/ \mathrm{TiO}_{2}$ nanocomposite for water remediation. J. Photochem. Photobiol. A 2016, 324, 117-125. [CrossRef] 
331. O'Regan, B.; Grätzel, M. A low-cost, high-efficiency solar cell based on dye-sensitized colloidal TiO 2 films. Nature 1991, 353, 737-740. [CrossRef]

332. Bach, U.; Lupo, D.; Comte, P.; Moser, J.E.; Weissörtel, F.; Salbeck, J.; Spreitzer, H.; Grätzel, M. Solid-state dye-sensitized mesoporous $\mathrm{TiO}_{2}$ solar cells with high photon-to-electron conversion efficiencies. Nature 1998, 395, 583-585. [CrossRef]

333. Acar, C.; Dincer, I.; Naterer, G.F. Review of photocatalytic water-splitting methods for sustainable hydrogen production. Int. J. Energy Res. 2016, 40, 1449-1473. [CrossRef]

334. Cao, S.; Yu, J. Carbon-based $\mathrm{H}_{2}$-production photocatalytic materials. J. Photochem. Photobiol. C 2016, 27, 72-99. [CrossRef]

335. Zhang, J.; Zhao, Y.; Guo, X.; Chen, C.; Dong, C.-L.; Liu, R.-S.; Han, C.-P.; Li, Y.; Gogotsi, Y.; Wang, G. Single platinum atoms immobilized on an mxene as an efficient catalyst for the hydrogen evolution reaction. Nat. Catal. 2018, 1, 985-992. [CrossRef]

336. Bi, L.; Gao, X.; Ma, Z.; Zhang, L.; Wang, D.; Xie, T. Enhanced separation efficiency of PtNi $/ \mathrm{g}-\mathrm{C}_{3} \mathrm{~N}_{4}$ for photocatalytic hydrogen production. ChemCatChem 2017, 9, 3779-3785. [CrossRef]

337. Zhang, W.; Lehmann, S.; Mergenthaler, K.; Wallentin, J.; Borgström, M.T.; Pistol, M.E.; Yartsev, A. Carrier recombination dynamics in sulfur-doped inp nanowires. Nano Lett. 2015, 15, 7238-7244. [CrossRef] [PubMed]

338. Ghosh, R.; Imakita, K.; Fujii, M.; Giri, P.K. Effect of Ag/Au bilayer assisted etching on the strongly enhanced photoluminescence and visible light photocatalysis by si nanowire arrays. Phys. Chem. Chem. Phys. 2016, 18, 7715-7727. [CrossRef] [PubMed]

339. Jiang, L.; Ni, S.; Liu, G.; Xu, X. Photocatalytic hydrogen production over aurivillius compound $\mathrm{Bi}_{3} \mathrm{TiNbO}_{9}$ and its modifications by $\mathrm{Cr} / \mathrm{Nb}$ co-doping. Appl. Catal. B Environ. 2017, 217, 342-352. [CrossRef]

340. Frank, S.N.; Bard, A.J. Heterogeneous photocatalytic oxidation of cyanide ion in aqueous solutions at titanium dioxide powder. J. Am. Chem. Soc. 1977, 8, 303-304. [CrossRef]

341. Wan, J. Application of the multiphase photocatalytic oxidation technologies in papermaking wastewater treatment. Trans. China Pulp Pap. 2002, 17, 119-121.

342. Devisscher, M.; Ciacci, G.; Fé, L.; Benedetti, L.; Bixio, D.; Thoeye, C.; De, G.G.; Marsililibelli, S.; Vanrolleghem, P.A. Estimating costs and benefits of advanced control for wastewater treatment plants-the MAgIC methodology. Water Sci. Technol. 2006, 53, 215-223. [CrossRef]

343. Wenzel, H.; Larsen, H.F.; Clauson-Kaas, J.; Høibye, L.; Jacobsen, B.N. Weighing environmental advantages and disadvantages of advanced wastewater treatment of micro-pollutants using environmental life cycle assessment. Water Sci. Technol. 2008, 57, 27-32. [CrossRef]

344. Rizzo, L. Water and wastewater treatment by heterogeneous photocatalysis: A review. In Handbook of Photocatalysts: Preparation, Structure and Applications; Castello, G.K., Ed.; Nova Science Publishers: New York, NY, USA, 2009; Chapter 7; ISBN 978-1-60876-210-1.

345. Chovelon, J.M.; Ferronato, C.; Fine, L. What Are the Main Factors Limiting the Industrial Implementation of Photocatalytic Reactors for Wastewater Treatment. 2018. Available online: https://hal.archives-ouvertes.fr/ hal-01677603/ (accessed on 16 September 2018).

346. Duraisamy, N.; Kandiah, K.; Rajendran, R.; Prabhu, S.; Ramesh, R.; Dhanaraj, G. Electrochemical and photocatalytic investigation of nickel oxide for energy storage and wastewater treatment. Res. Chem. Intermed. 2018, 44, 5653-5667. [CrossRef]

347. Sacco, O.; Vaiano, V.; Rizzo, L.; Sannino, D. Photocatalytic activity of a visible light active structured photocatalyst developed for municipal wastewater treatment. J. Clean. Prod. 2018, 175, 38-49. [CrossRef]

348. Wong, S.P.; Kanakaraju, D. Photocatalytic efficiency of $\mathrm{TiO}_{2}$-biomass loaded mixture for wastewater treatment. J. Chem. 2018, 2018, 1-14.

349. Zakeritabar, S.F.; Jahanshahi, M.; Peyravi, M. Photocatalytic behavior of induced membrane by $\mathrm{ZrO}_{2}-\mathrm{SnO}_{2}$ nanocomposite for pharmaceutical wastewater treatment. Catal. Lett. 2018, 148, 882-893. [CrossRef]

350. Li Puma, G. Dimensionless analysis of photocatalytic reactors using suspended solid photocatalysts. Chem. Eng. Res. Des. 2005, 83, 820-826. [CrossRef]

351. Houas, A.; Lachheb, H.; Ksibi, M.; Elaloui, E.; Guillard, C.; Herrmann, J.-M. Photocatalytic degradation pathway of methylene blue in water. Appl. Catal. B Environ. 2001, 31, 145-157. [CrossRef]

352. Lachheb, H.; Puzenat, E.; Houas, A.; Ksibi, M.; Elaloui, E.; Guillard, C.; Herrmann, J.-M. Photocatalytic degradation of various types of dyes (Alizarin S, Crocein Orange G, Methyl Red, Congo Red, Methylene Blue) in water by UV-irradiated titania. Appl. Catal. B Environ. 2002, 39, 75-90. [CrossRef] 
353. Regmi, C.; Kshetri, Y.K.; Kim, T.H.; Pandey, R.P.; Ray, S.K.; Lee, S.W. Fabrication of Ni-doped BiVO 4 semiconductors with enhanced visible-light photocatalytic performances for wastewater treatment. Appl. Surf. Sci. 2017, 413, 253-265. [CrossRef]

354. Cai, Z.; Xiong, Z.; Lu, X.; Teng, J. Insitu gold-loaded titania photonic crystals with enhanced photocatalytic activity. J. Mater. Chem. A 2013, 2, 545-553. [CrossRef]

355. Cai, Z.; Teng, J.; Xiong, Z.; Li, Y.; Li, Q.; Lu, X.; Zhao, X.S. Fabrication of $\mathrm{TiO}_{2}$ binary inverse opals without overlayers via the sandwich-vacuum infiltration of precursor. Langmuir ACS J. Surf. Colloids 2011, 27, 5157-5164. [CrossRef]

356. Zhao, X.; Liu, H.; Shen, Y.; Qu, J. Photocatalytic reduction of bromate at $\mathrm{C}_{60}$ modified $\mathrm{Bi}_{2} \mathrm{MoO}_{6}$ under visible light irradiation. Appl. Catal. B Environ. 2011, 106, 63-68. [CrossRef]

357. Matsunaga, T.; Tomoda, R.; Nakajima, T.; Wake, H. Photoelectrochemical sterilization of microbial cells by semiconductor powders. FEMS Microbiol. Lett. 1985, 29, 211-214. [CrossRef]

358. Chen, L.; He, F.; Huang, Y.; Meng, Y.; Guo, R. Hydrogenated nanoporous $\mathrm{TiO}_{2}$ film on Ti-25Nb-3Mo-2Sn-3Zr alloy with enhanced photocatalytic and sterilization activities driven by visible light. J. Alloys Compd. 2016, 678, 5-11. [CrossRef]

359. Tian, Y.; Zhou, F.; Zhan, S.; Yang, Y.; Liu, Y.; He, Q. Mechanisms on the sterilization performance of fluorocarbon resin composite coatings enhanced by g- $\mathrm{C}_{3} \mathrm{~N}_{4} / \mathrm{TiO}_{2}$. J. Inorg. Organomet. Polym. Mater. 2017, 27, 353-362. [CrossRef]

360. Yan, L.L.; Wang, Y.; Xiong, L.B.; Li, J.L.; Yip, H.Y.; Wong, P.K.; Yu, Y. Preparation and photocatalytic sterilization property of $\mathrm{Cu}_{2} \mathrm{O}$ nanostructure with copper anode oxidation method. Chin. J. Inorg. Chem. 2009, 25, 1960-1964.

361. Kim, B.-H.; Kim, D.; Cho, D.-L.; Lim, S.-H.; Yoo, S.y.; Kook, J.-k.; Cho, Y.i.; Ohk, S.-H.; Ko, Y.-M. Sterilization effects of a $\mathrm{TiO}_{2}$ photocatalytic film against a streptococcus mutans culture. Biotechnol. Bioprocess. Eng. 2007, 12, 136-139. [CrossRef]

362. Jones, N.; Ray, B.; Ranjit, K.T.; Manna, A.C. Antibacterial activity of zno nanoparticle suspensions on a broad spectrum of microorganisms. FEMS Microbiol. Lett. 2010, 279, 71-76. [CrossRef] [PubMed]

363. Adams, L.K.; Lyon, D.Y.; Alvarez, P.J.J. Comparative eco-toxicity of nanoscale $\mathrm{TiO}_{2}, \mathrm{SiO}_{2}$, and $\mathrm{ZnO}$ water suspensions. Water Res. 2006, 40, 3527-3532. [CrossRef]

364. Zhao, H.; Tian, F.; Wang, R.; Chen, R. A review on bismuth-related nanomaterials for photocatalysis. Rev. Adv. Sci. Eng. 2014, 3, 3-27. [CrossRef]

365. Matos, J.; Llano, B.; Montaña, R.; Poon, P.S.; Hidalgo, M.C. Design of Ag/ and $\mathrm{Pt} / \mathrm{TiO}_{2}-\mathrm{SiO}_{2}$ nanomaterials for the photocatalytic degradation of phenol under solar irradiation. Environ. Sci. Pollut. Res. 2018, 25, 18894-18913. [CrossRef] [PubMed]

366. Qin, Z.; Su, T.; Ji, H.; Guo, Z.; Chen, Y.; Lu, N.L. Photocatalytic Nanomaterials for the Energy and environmental application. Multifunct. Nanocompos. Energy Environ. Appl. 2018, 2, 353-401.

367. Song, Y.S.; Kim, Y.; Lee, H.; Lee, D.Y.; Lee, M.H.; Kim, B.Y. Photocatalytic activity of $\mathrm{Al}^{-\mathrm{TiO}_{2}}$ nanomaterials for the degradation of methylene blue dye. J. Korean Phys. Soc. 2018, 72, 412-416. [CrossRef]

368. Obuchi, E.; Furusho, T.; Katoh, K.; Soejima, T.; Nakano, K. Photocatalytic disinfection of sporulating bacillus subtilis using silver-doped $\mathrm{TiO}_{2} / \mathrm{SiO}_{2}$. J. Water Process Eng. 2017. [CrossRef]

369. Guzman, M.I. Prebiotic metabolism: Production by mineral photoelectrochemistry of alpha-ketocarboxylic acids in the reductive tricarboxylic acid cycle. Astrobiology 2009, 9, 833-842. [CrossRef] [PubMed]

370. Eggins, B.R.; Robertson, P.K.J.; Stewart, J.H.; Woods, E. Photoreduction of carbon dioxide on zinc sulfide to give four-carbon and two-carbon acids. J. Chem. Soc. Chem. Commun. 1993, 24, 349-350. [CrossRef]

371. D'hennezel, O.; Pichat, P.; Ollis, D.F. Benzene and toluene gas-phase photocatalytic degradation over $\mathrm{H}_{2} \mathrm{O}$ and $\mathrm{HCl}$ pretreated $\mathrm{TiO}_{2}$ : By-products and mechanisms. J. Photochem. Photobiol. A 1998, 118, 197-204. [CrossRef]

372. Pichat, P.; Disdier, J.; Hoang-Van, C.; Mas, D.; Goutailler, G.; Gaysse, C. Purification/deodorization of indoor air and gaseous effluents by $\mathrm{TiO}_{2}$ photocatalysis. Catal. Today 2000, 63, 363-369. [CrossRef]

373. Alberici, R.M.; Jardim, W.F. Photocatalytic destruction of vocs in the gas-phase using titanium dioxide. Appl. Catal. B Environ. 1997, 14, 55-68. [CrossRef]

374. Vandenbroucke, A.M.; Morent, R.; De, G.N.; Leys, C. Non-thermal plasmas for non-catalytic and catalytic voc abatement. J. Hazard. Mater. 2011, 195, 30-54. [CrossRef] 
375. Li, F.B.; Li, X.Z.; Ao, C.H.; Lee, S.C.; Hou, M.F. Enhanced photocatalytic degradation of VOCs using $\mathrm{Ln}^{3+}-\mathrm{TiO}_{2}$ catalysts for indoor air purification. Chemosphere 2005, 59, 787-800. [CrossRef]

376. Lin, L.; Chai, Y.; Zhao, B.; Wei, W.; He, D.; He, B.; Tang, Q. Photocatalytic oxidation for degradation of VOCs. Open J. Inorg. Chem. 2013, 03, 14-25. [CrossRef]

377. Lugo Vega, C.S. Evaluation of VOC Degradation in Photo-Catalytic Air Reactors: $\mathrm{TiO}_{2}$ Immobilization, Energy Efficiency and Kinetic Modeling. Ph.D. Thesis, The University of Western Ontario, London, ON, Canada, 2016. Available online: https://ir.lib.uwo.ca/etd/4019 (accessed on 16 September 2018).

378. Mamaghani, A.H.; Haghighat, F.; Lee, C.S. Photocatalytic degradation of VOCs on various commercial titanium dioxides: Impact of operating parameters on removal efficiency and by-products generation. Build. Environ. 2018, 138, 275-282. [CrossRef]

379. Stucchi, M.; Galli, F.; Bianchi, C.L.; Pirola, C.; Boffito, D.C.; Biasioli, F.; Capucci, V. Simultaneous photodegradation of voc mixture by $\mathrm{TiO}_{2}$ powders. Chemosphere 2018, 193, 198-206. [CrossRef] [PubMed]

380. Zallouha, M.A.; Landkocz, Y.; Brunet, J.; Cousin, R.; Genty, E.; Courcot, D.; Siffert, S.; Shirali, P.; Billet, S. Usefulness of toxicological validation of VOCs catalytic degradation by air-liquid interface exposure system. Environ. Res. 2017, 152, 328-335. [CrossRef] [PubMed]

381. Mishra, A.; Mehta, A.; Kainth, S.; Basu, S. Effect of different plasmonic metals on photocatalytic degradation of volatile organic compounds (VOCs) by bentonite/ $\mathrm{M}-\mathrm{TiO}_{2}$ nanocomposites under UV/visible light. Appl. Clay Sci. 2018, 153, 144-153. [CrossRef]

382. Weilin, G.E.; Qian, J.; Siyao, X.U.; Sen, L.I. Catalytic degradation of volatile organic compounds over $\mathrm{Cr}-\mathrm{Ce} / \mathrm{Al}_{2} \mathrm{O}_{3}$ catalysts. Chin. J. Environ. Eng. 2018, 12, 374-381.

(C) 2019 by the authors. Licensee MDPI, Basel, Switzerland. This article is an open access article distributed under the terms and conditions of the Creative Commons Attribution (CC BY) license (http://creativecommons.org/licenses/by/4.0/). 